Historic, Archive Document

Do not assume content reflects current scientific knowledge, policies, or practices. 



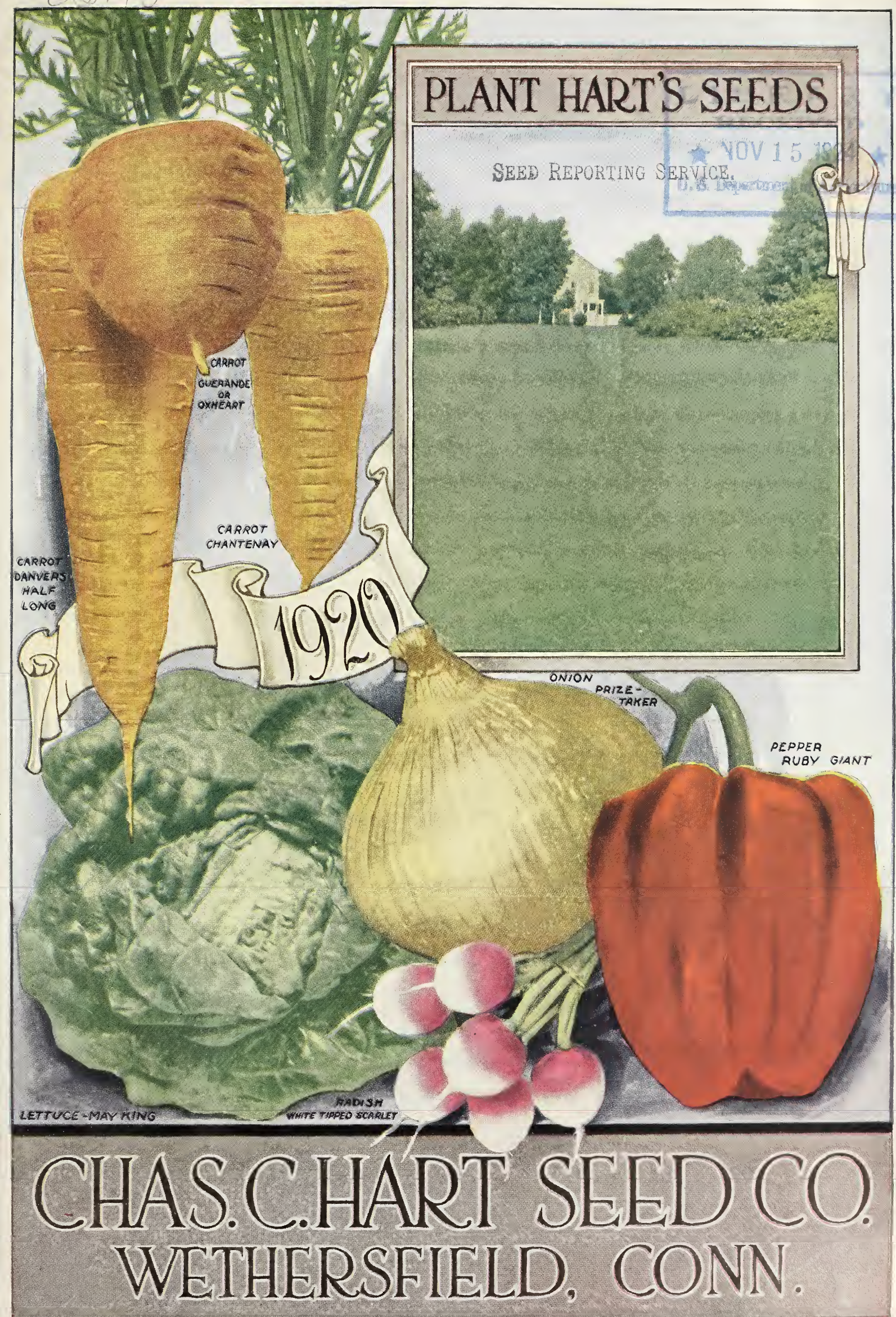




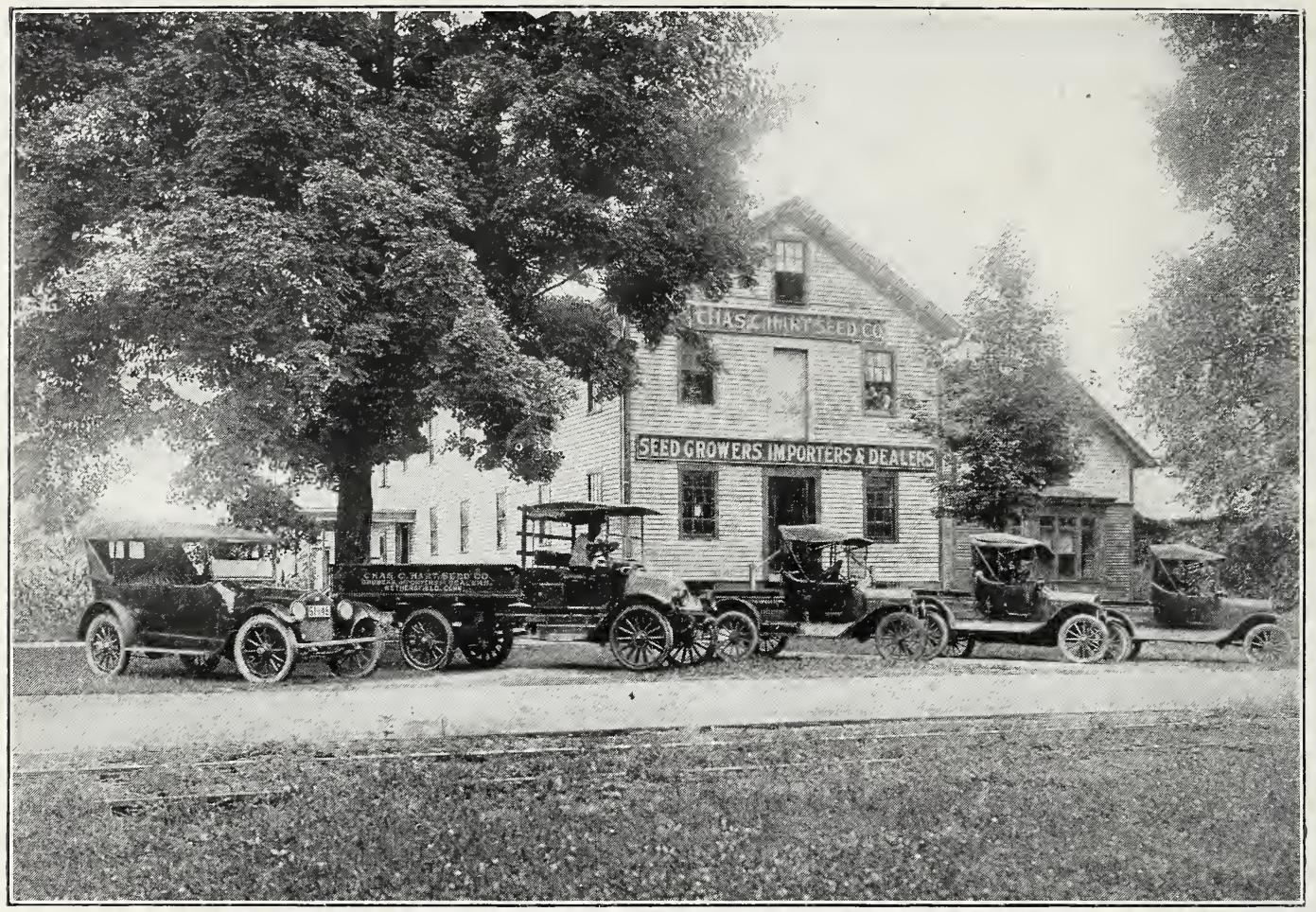

Office and Warehouse

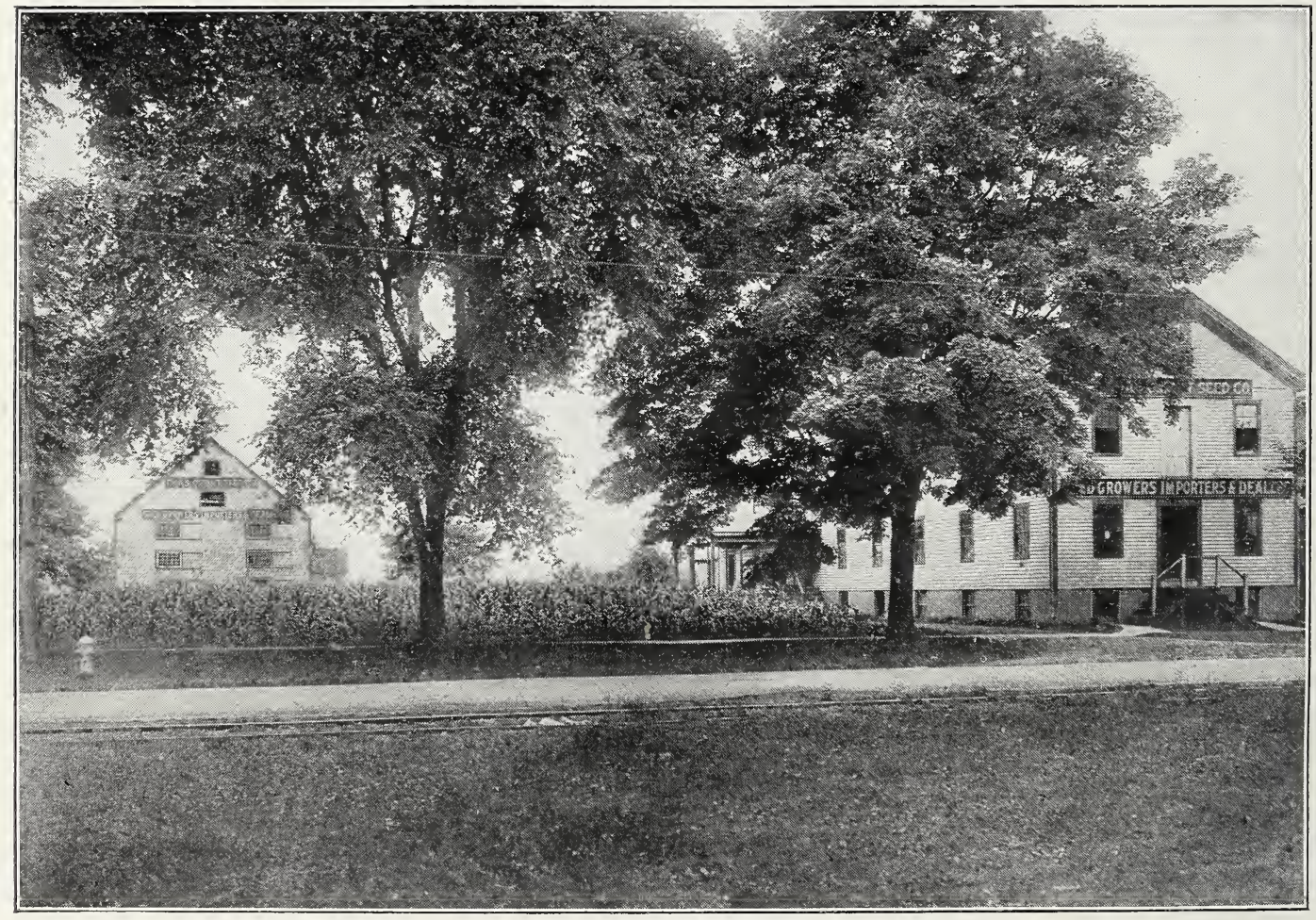

Seed Warehouse, with one of our Corn Drying Barns in the rear and a small field of Black Mexican Sweet Corn in front 


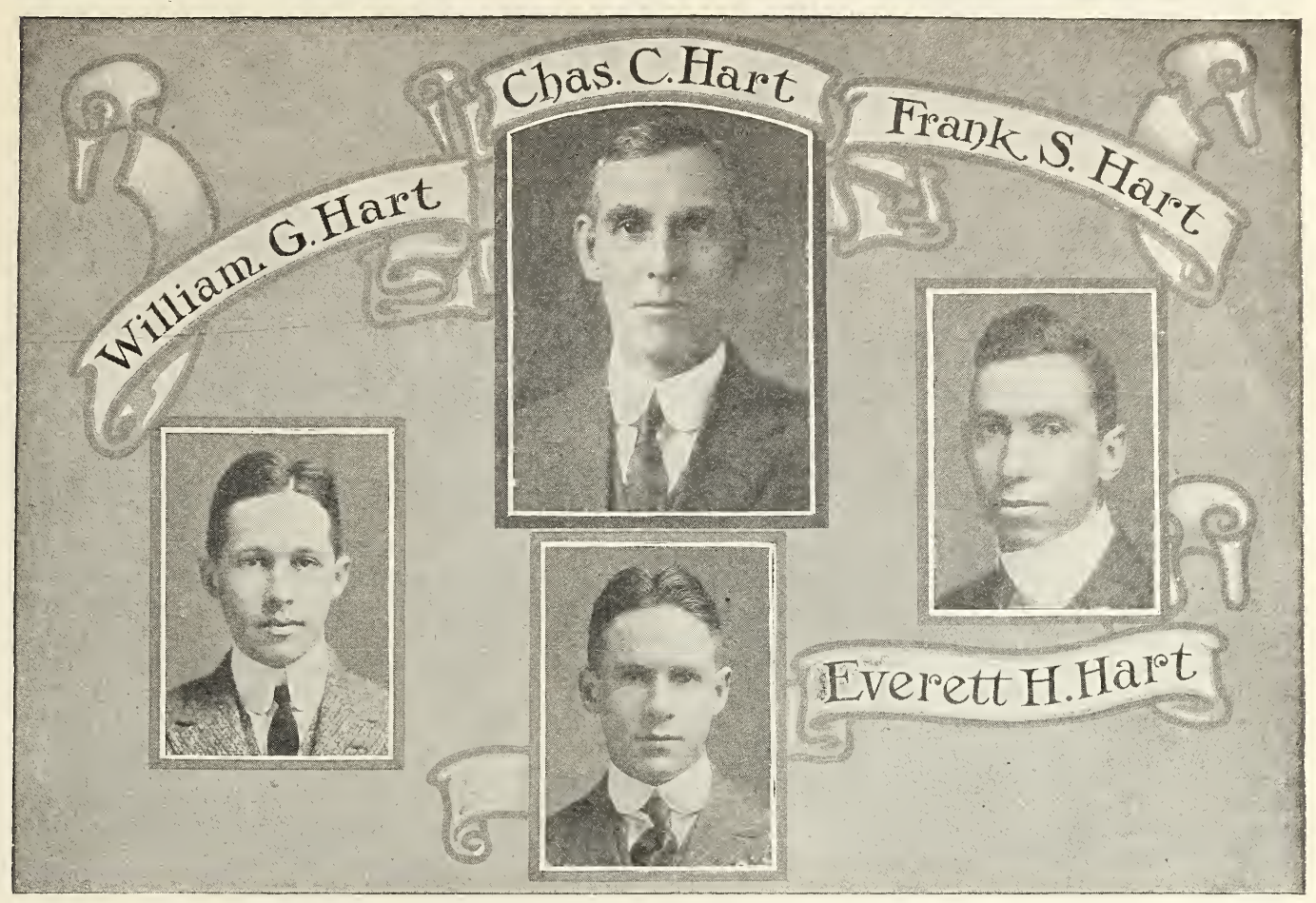

Dear Friends:

We take great pleasure in presenting our seed Catalogue for the season of 1920 and feel confident that a careful study of its contents will prove both profitable and interesting.

We thank our many friends for the confidence they have placed in us by favoring us with their business, and for the many letters received expressing satisfaction and good will; such confidence is most pleasing and inspiring. We assure our friends that we will in the future as in the past, work for the interest of our customers and will try to merit a continuance of their business and good will.

We are all vitally interested in the present problem concerning the "high cost of living," and how best to combat it. What better and more logical way than by increasing production? Make the farm and home garden produce more and better vegetables, fruit and grain. Surround the home with beautiful flowers and a well kept lawn. Make it the most attractive and beautiful place in your town. Be 100 per cent. American. Our responsibility did not cease with the end of the Great War. It is our duty to continue to "make the world a better place to live in." This thought should stimulate us all to aid in bringing about better conditions by an increased production in all lines.

We are prepared to do our part to aid in this progressive movement and offer the choicest stocks and best seeds obtainable at the lowest prices consistent with high quality and cost of production.

We are happy to state our Mr. Everett H. Hart, after serving 18 months in France as Platoon Sergeant in the 101st M. G. Bn., 26th Division, is again with us and has taken up his duties, and his safe return encourages us to renewed efforts and a desire to give better service than ever before.

Realizing that most people like to see with whom they are doing business we are pleased to introduce the members of our firm in the group above and sincerely hope that we may have the pleasure of a personal acquaintance and a share of your valued business.

Cordially yours, 


\section{How to Order}

It will be to your advantage to order early.

Every inquiry will receive a prompt and courteous reply, and the smallest order will receive the same careful attention as a large one.

TERMS. Our terms are strictly cash with orders.

HOW TO SEND MONEY. Money may be safely sent by Post Office or Express Money Orders, Registered Letter or Bank Draft. Personal Checks - if you have the money back of them, send them right along; you are the class of customer we want. We will accept postage stamps, if received in good condition, for amounts up to $\$ 1.00$.

Seeds may be sent by Parcel Post, up to $50 \mathrm{lbs}$. in the 1st and $2 \mathrm{~d}$ zone limit of 150 miles; and up to $20 \mathrm{lbs}$. in the $3 \mathrm{~d}$ zone limit of 300 miles. See table of postage rates.

Postage - see note below-If in large quantities and no shipping instructions are given we will ship cheapest and best way, either by express or freight, and transportation charges must be paid by purchaser.

Remember, name and address should always be given. Use our order sheet and envelope, filling out the blank, and signing your name and P. O. address piainly, and your order will receive prompt and careful attention.

Cloth Bags. When ordering 4 quarts, pecks, $1 / 2$ bushel and over, cloth bags must be used in packing and cost of bags added. We charge 10c. for 4 -quart and peck bags, $25 \mathrm{c}$. for $1 / 2$-bushel bags, 60c. for twobushel bags, and 50c. for barrels. If customers wish to return bags and will send by Parcel Post, prepaid, we will refund money paid us for them. Barrels are not returnable.

If your local dealer handles our seeds in bulk they will be the same good quality seeds as you would get direct from us. If he does not handle them, send to us.

GUARANTEE. Our seeds are all tested before they are sent out, and we know they will sprout, and believe they will produce the variety represented, but there are so many contingencies continually arising which prevent the best seeds from always giving satisfaction, and which is in no way the fault of the seeds, that we can give no warranty, express or implied, as to description, quality or productiveness, or any other matter of any seeds, bulbs, plants, roots or trees that we send out, and we will not be in any way responsible for the crop.

Please remember that while we cannot guarantee crops, it is to our interest to give you the best there is, and we trust you will have confidence enough in us to believe we will do so.

If you change your address, kindly notify us. If you have no use for this catalogue please pass it to someone who will be interested in it.

We shall be pleased to hear from you, and with our best wishes, we are, Sincerely yours,

United States Food Administration License, No. G247o8.

CHAS. C. HART SEED CO.

POSTAGE. We will pay postage on SEEDS up to $6 \mathrm{lbs}$., which will be 10 cents on every order sent by parcel post. Each additional pound over the 6 LBS. FREE, add 1 cent, to be paid by the purhaser, and added to amount of seed order. Postage on Asparagus Roots, Onion Sets, Potatoes, and all express and freight charges, to be paid by purchaser.

\section{Parcel Post Rates}

\begin{tabular}{|c|c|c|c|c|c|c|c|c|c|}
\hline 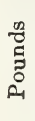 & 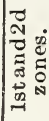 & $\begin{array}{l}0 \\
0 \\
0 \\
0 \\
\text { D }\end{array}$ & $\begin{array}{l}\dot{0} \\
\text { ż } \\
\tilde{J} \\
0 \\
\text { f }_{1}\end{array}$ & 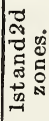 & 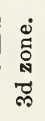 & $\begin{array}{l}\dot{\delta} \\
\tilde{z} \\
\tilde{\Xi} \\
\tilde{D}_{1}\end{array}$ & 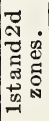 & 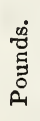 & 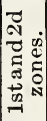 \\
\hline & $\mathrm{Cts}$ & Cts. & & Cts. & Cts. & & $\overline{\mathrm{Cts}}$ & & ICts. \\
\hline 1 & 5 & 6 & 15 & 19 & 34 & 29 & 33 & 43 & 47 \\
\hline 2 & 6 & 8 & 16 & 20 & 36 & 30 & 34 & 44 & 48 \\
\hline 3 & 7 & 10 & 17 & 21 & 38 & 31 & 35 & 45 & 4 \\
\hline 4 & 8 & 12 & 18 & 22 & 40 & 32 & 36 & 46 & 50 \\
\hline 5 & 9 & 14 & 19 & 23 & 42 & 33 & 37 & 47 & 5 \\
\hline 6 & 10 & 16 & 20 & 24 & 44 & 34 & 38 & 48 & 52 \\
\hline 7 & 11 & 18 & 21 & 25 & .. & 35 & 39 & 49 & 53 \\
\hline 8 & 12 & 20 & 22 & 26 & & 36 & 40 & 50 & 54 \\
\hline 9 & 13 & 22 & 23 & 27 & & 37 & 41 & . & • \\
\hline 10 & 14 & 24 & 24 & 28 & & 38 & 42 & & \\
\hline 11 & 15 & 26 & 25 & 29 & & 39 & 43 & • & \\
\hline 12 & 16 & 28 & 26 & 30 & . & 40 & 44 & . & \\
\hline 13 & 17 & 30 & 27 & 31 & . & 41 & 45 & . & \\
\hline 14 & 18 & 32 & 28 & 32 & . & 42 & 46 & & \\
\hline
\end{tabular}

Weight limit, $50 \mathrm{lbs}$. in first and second zones of 150 miles, and 20 lbs. in third zone of 300 miles. Measurement limit, around package, both ways, 72 inches in all zones.

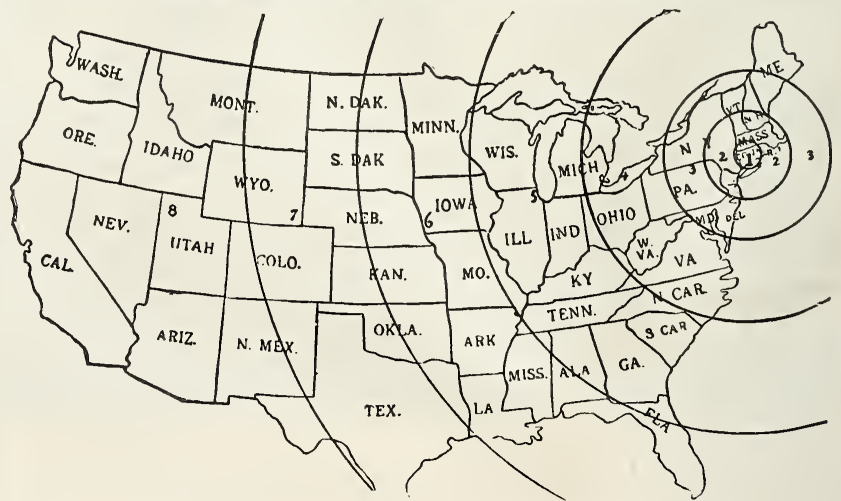




\section{Hints and Suggestions for Your Vegetable Garden}

The Great War has thoroughly established the American vegetable garden. Thousands of amateur gardeners having learned the value of fresh vegetables, will never again willingly put up with the stale products from grocery or peddler's wagon. They have learned to take pride in their garden and they appreciate its economic and health value; economic because of the money saved, and healthful through the bodily exercise, the change of employment, and the palatable and nourishing food secured. What is more delicious than a steaming ear of Corn? Freshly picked green Peas? Or a luscious Melon? What more appetizing or nourishing than good old-fashioned New England baked beans? And all the product of your own garden. More vegetables and fruit, and less meat will work wonders in the development of vigorous red-blooded Americans.

Any one can have a good vegetable garden by following the suggestions given, using diligence and common sense, and a little "elbow grease." Prepare soil; use garden fertilizers; buy good seed; cultivate the crop; control insects and diseases intelligently.

Unless vegetables are grown rapidly and continuously, not only is their quality poor, but quantity is sacrificed as well. The highest quality only should be the aim of every gardener and to assist him to that end is the object of these pages.

The Garden Site.-Many gardeners have no range of choice in the location of their garden, but if it can be so situated, it should have all the sunshine possible and be in a well-drained spot. Clean your land of weeds and rubbish. Such material will be greatly in the way when spading, sowing seed, or hoeing.

Planning a Small Garden.-Where space is limited one is apt to make mistakes unless he has planned out the most economical way of arrangement. Usually in a very small space, one cannot afford to grow vegetables that take up too much room, such as Corn, Potatoes, etc., but such things as Beans, early Peas, Lettuce, Radish and Spinach will give the best returns on a limited space. Then it is possible by a little scheming to grow three and four crops on the same land during one season. Even with a limited space, if given high culture, one can grow an enormous amount of food if he will devote a little time to planning, so that all of the ground may be producing something throughout the entire season.

Soil and Manure.-All soil should be made loose and friable; in that condition it is moisture holding, gives a better chance for a well-balanced root system, and provides for the proper aeration of the roots, besides making some of the plant foods available.

In order to make soil loose, plenty of organic matter, such as manure, or decayed leaves should be added to it. Where manure is difflcult to obtain, sifted coal ashes will assist in loosening the soil, but will in no way add to the fertility. If it is possible, obtain well rotted stable manure, and apply it in the Fall. As soon as the ground can be worked in the Spring, spade the manure in deeply and at the same time on very heavy soil, a coating of sifted coal ashes may be used.

Hen, or sheep manure are much more powerful than horse or cow manure in their action, and care should be used to spade it in deeply. Where manure is unobtainable, and commercial fertilizer difflcult, or inconvenient to obtain, we would recommend the use of Inoculating Bacteria, which is put up in garden sizes, with directions for use and can be mailed promptly to any address.

Lime.-The use of slacked lime will be found highly beneficial. It seems to make heavier soil loose; it affects the sandier soils and makes them more moisture-holding; it sweetens the sour soils, and by its chemical influence with certain of the substances in the soil, it renders available a liberal share of the earth's store house of food. A 50-lb. sack to a plot $30 \times 40$ feet will be sufficient. Use in Spring after ploughing and rake in. Do not use it where Potatoes are to be planted.

Fall Plowing Preferable.-It is best to plow the garden in the Fall, because the frost will pulverize the soil into fine mealy particles. Fall plowed land dries out more quickly, so that it may be planted earlier. Have the garden spot plowed deeply and the furrows cut narrow. Many of the root crops go deeply, and require thorough preparation. If you are plowing new land, especially that which has been in sod, you must not expect too much the first year. Such soil will grow Beans, Potatoes, Corn, Cabbage and Tomatoes better than some of the other crops. The constant stirring of the soil in growing Potatoes and Corn will fit it nicely for better results next season.

Spading.-There would be no occasion to spade only the smaller garden plots, but there is no doubt but that thorough spading is more efficient than plowing. The sandier soils will allow spading much earlier than the heavy or clay soils. Soil that adheres together in a heavy clump is too wet for working. Allow sucl soil to dry a little more, because if too wet the clods will of ten remain unbroken throughout the whole Summer, baking harder and harder as they become dry.

Planting. Plant as early as possible. Everything in rows. Use a garden line. Time spent in proper spacing of seeds will be well repaid when it comes to thinning out. The weeding and cultivating will be so much more easy to attend to. Wherever possible let the rows run north and south in order to get the direct rays of the sun. In sowing seeds care should be used not to cover finer seeds too deeply, as the tender sprouts will not have strength enough to push up through the soil, or take so long that the weeds get started, and choke out the young plant and the gardener lays the failure to the seeds being poor. Mark out shallow rows with tip of hoe, or hand marker, cover with thickness of seed and pressitfirmly into the soil, and keep the soil between the rows thoroughly cultivated to prevent baking. In sowing Celery seed, mark out the row and simply press the seed into the soil, using a narrow board for this purpose. Celery seed is so slow to germinate, it is a good plan to cover the rows with narrow boards, to retain the moisture, and prevent weeds from starting. As soon as seed has sprouted and come through the ground, the boards should be removed.

Seeds. - The best seed is never too good. Poor, or inferior seeds, no matter how cheap the price, are the most expensive in the end. Seeds should be purchased only from a reliable seedsman who has a reputation he must protect. The very best culture cannot make up for poor seed.

The Hoe vs. The Hose. From the moment that the seed is sown or the plants are set in the field, the hoe must be ready for use. Keep the soil thoroughly pulverized, never allow it to bake. One of the great benefits to the garden which comes from frequent shallow hoeings is that this operation surrounds the plants with a dust-like covering of soil which keeps the moisturefrom evaporating. Nearly every person has seen how a lamp wick sucks oil up from the oil tank. The oil is lifted by a scientific principle known as "capillary attraction." The moisture in the soil is lifted the same way. When soil is packed hard it acts as a wick, and the moisture evaporates when it reaches the surface. The dust cover, or dust "mulch" as it is called, stops this wick action and holds the water in the soil.

During dry spells, however, it is necessary to water the garden artificially for best results. It is better to water in the early morning, or late afternoon, but as a rule, the benefit is greater about sundown. 


\section{HINTS AND SUGGESTIONS FOR YOUR VEGETABLE GARDEN-Continued}

Thinning.-Seeds of most plants are usually sown more thickly than the plant should be allowed to grow, not only is it very difflcult to sow seeds just right, but seeds that are sown thickly assist each other in breaking through the ground, and are less apt to be destroyed by the tender shoot breaking off, in trying to force its way singly through the crusted soil. When these plants often coming up thickly together are big enough to handle, they should be thinned out; those remaining will give a greater crop of a better quality. Thin enough so that the roots of each plant have plenty of room to spread out and seek the plant food in the soil. By having the monopoly of all the food within its little area the plant will grow vigorously. This explains why it is important to keep out all weeds which attempt to share this plant food with the valuable vegetables.

Sanitation in the Garden.-The pests of the garden are numerous and the home gardener must ever be diligent. Much can be accomplished in the control of insects and diseases that infest garden crops by careful sanitary management. In the Fall after the crops have been harvested, or as fast as any crop is disposed of, any refuse that remains should be gathered and placed in the compost heap, or burned if diseased or infested with insects. Many of the garden insects find protection during the Winter under boards and any loose material that may remain in the garden. Dead vines or leaves of plants are frequently covered with spores of diseases that affect those crops during the growing season, and these should be burned, as they possess very little fertilizing value. Weeds often harbor the same insects and diseases as are destructive to the vegetable. A great amount of labor can be saved in the Spring, by burning the trash in the Fall.

Preparedness.-The wise gardener follows the old aphorism "an ounce of prevention is better than a pound of cure." In the garden, as in the world in general, the pacifist is supplanted by advocates of preparedness. Get a good spray pump. Stock up with insecticides and fungicides. Insects and diseases require vigorous treatment.

Plant Diseases.-Plant diseases are never cured, but they can be prevented from spreading. One of the most common diseases of the garden is the blight of Potatoes. A spraying of Bordeaux Mixture very early in the Spring and several times during the season may keep this blight in subjection. Bordeaux Mixture is frequently mixed with Arsenate of Lead, and this double-purpose spray serves to keep both the blight disease and the Potato bug under control. Gardeners should watch all their crops closely and if unacquainted with the means to be used to combat diseases or insect pests, they should immediately consult a good book on the subject, or their seedsman as to what to use. There are obtainable from your seedsman, standard preparations for all troubles. These are ready for use and are easy to handle.

Beetles, Caterpillars and Worms. There are two classes of insects which bother all gardens; the first have chewing mouth parts to which belong the whole class of beetles, caterpillars and worms. They eat the leaves and if the leaves have poison spread upon them, they take the poison along with the leaf. Nothing is so good for this class of insect as arsenate of lead.

Aphids, or Plant Lice.-The second class of insects have piercing and sucking mouth parts. The plant louse and green fly, or Aphis is an example of this sort of insect. They are controlled by spraying with a solution of Kerosene Emulsion. In controlling plant lice it is absolutely necessary to hit the insect with strong force and so clog its pores with the solution that it will be suffocated. As there are a great many generations born each season frequent spraying is absolutely necessary.
Insects in the Soil.-Some insects which are found in the soil are difficult to control and the best precaution is to plant the crop in a different place each year, thereby evading the pest. Especially is this true of Radishes which is affected by a Radish worm. Sometimes root lice are found; these may be controlled by placing tobacco stems along the rows.

Borers.-There is a large class of boring insects which are very destructive in the garden. Unfortunately these borers cannot be killed by sprays. They get inside the stems where they cannot be reached. Squash can often be saved by covering the vines at each joint with soil in order to encourage these to root. If one wishes to go to the trouble, he can use a small penknife and dig the borer out of the stem by merely making a slight longitudinal cut. Usually the plant is not killed by this operation but it would surely die if the borer were allowed to work. A borer is known to be at work when the foliage suddenly wilts and turns yellow.

\section{COMPAINION CROPS}

Crops that may be planted together in the same space and occupy the same ground together are known as companion crops.

Between the rows of early Cabbage may be planted Lettuce or Radishes.

In the row with Onions, Parsnip and Carrots, Lettuce and Radishes may be sown thinly.

Lettuce, Radish or Spinach may be sown between Tomato plants.

Squash may be planted among early Sweet Corn.

Onion Sets may be planted between the early Cabbages.

Radishes, early Beets, early Carrots and early Turnip may be planted between the rows of Peas.

Pole Beans may be planted with the early Sweet Corn.

Early Potatoes may be planted between rows of Melons.

\section{SUCCESSION CROPS.}

Succession crops are those which follow each other. Celery plants may be set to follow early Peas, Beans, Radish, Lettuce, Onion, Spinach and other crops.

Turnip may be sown in any spot made vacant by the early crops.

Beans or Turnips can be planted between rows of early Sweet Corn.

Early Potatoes may be followed by early Sweet Corn, Celery plants, Beans, Beets, Carrots or Spinach.

Lettuce may be followed by Summer Radishes and these by Beans and the Beans by Spinach.

Lettuce, Radish and Spinach may be sown throughout the season.

Tomato and Pepper plants, Beans or early Sweet Corn may follow Peas and Onion Sets.

Early Peas, Beets or Potatoes may be cleared away for Turnips, String Beans, or Winter Radishes.

String Beans may be followed by Lettuce, Radish, Spinach or Turnips.

Spinach may be followed by early Sweet Corn, String Beans or Cabbage or by Winter Squash.

The quantities and varieties of palatable regetables that can be grown by a succession of crops is really wonderful. As the early Summer vegetables are finished, plant over again; they are just as palatable in the Autumn as they were in the Spring.
East Jaffrey, N. H.

"Have been using your seeds for the past six years and always have had the best of luck with them."
"Your Corn Shelburne Falls, Mass. from any Seed Co. before." Yours truly,
L. D. 


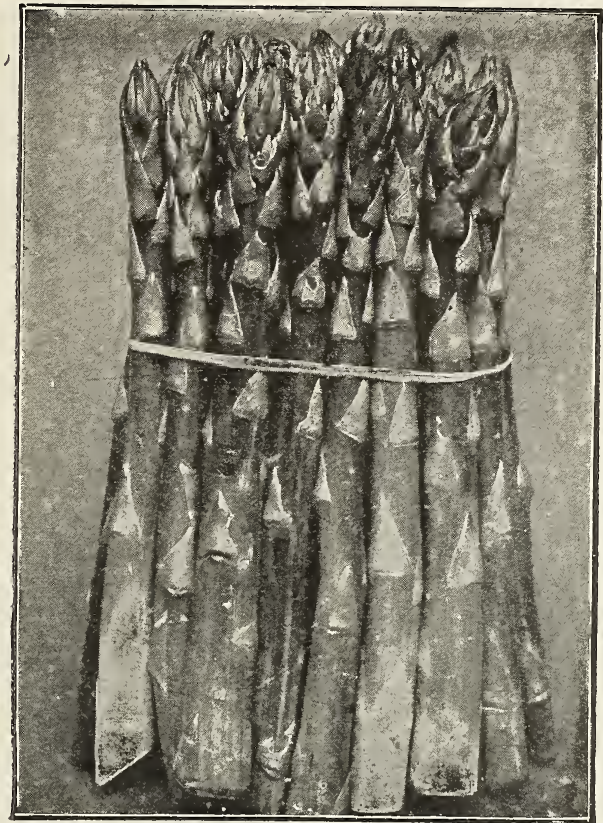

Palmetto Asparagus

\section{ASPARAGUS}

\author{
4 to $5 \mathrm{lbs}$. to the acre.
}

Culture.-Sow the seed as early in Spring as ground can be worked, in drills I 2 to I4 inches apart. When two years old, transplant into permanent beds, well and deeply manured. In setting the roots, spread them out well and cover them to the depth of 6 inches. Very little, if any, should be cut the first year after transplanting, but a fair crop can be cut the second year. Later in the season all the shoots should be allowed to run to seed, and in the Fall all the tops should be cut off, the ground cleaned up, and a good dressing of manure and wood ashes spaded into the bed. An occasional dressing of salt is beneficial and keeps down the weeds.

Conover's Colossal. The standard variety, and very tender. Pkt. 5c., oz. Ioc., 1/4 lb. 25c., 1b. $75 \mathrm{c}$.

Columbia Mammoth White. A large, thick variety; very white, even above ground. Pkt. $5 \mathrm{c} ., \mathrm{oz}$. IOc., $1 / 4$ lb. $25 \mathrm{c}$., $1 \mathrm{~b} .75 \mathrm{c}$.

Palmetto. A large, early variety; very popular, and good for shipping. Pkt. $5 \mathrm{c}$., oz. IOc., $1 / 4 \mathrm{lb}$. $25 \mathrm{c}$.; lb. $75 \mathrm{c}$.

\section{Asparagus Roots}

Strong, 2-year-old roots of the above. Per 50, 6oc., per I0o, $75 \mathrm{c}$.; per I000, $\$ 6.00$.

Strong, 3-year-old roots, 50 for $75 \mathrm{c}$., I00 for $\$ \mathrm{I} .00$, I000 for $\$ 6.50$.

50 roots will require $8 \mathrm{c}$. postage.

\section{BEANS}

Culture.-Beans require a light, well-drained soil, and should not be planted too early, as they are very sensitive to cold and wet. Plant usually around the first of May, and at intervals throughout the season for a succession, until the latter part of August. Plant in drills about 2 feet apart, and 5 or 6 plants to the foot. Keep well cultivated.

\section{Dwarf, Green-Podded, Bush or Snap}

\section{1 qt. weighs about 2 lbs.}

Burpee's Stringless Green Pod. An extra early, round-podded, prolific sort, bearing. numerous long bright green stringless pods of excellent quality. Very desirable for both the home garden, and for market. Pkt. Ioc., 1/2 lb. 20c., I lb. and over 30c. 1b.

Extra Early Red Valentine. One of the best of the early green-podded sorts both for the home and the market garden. The pods are medium length, very fleshy, crisp and tender. Pkt. IOc., 1/2 lb. 20c., I lb. and over $30 \mathrm{c}$. $\mathrm{lb}$.

Black Valentine. Follows Red Valentine in earliness, but pods are much longer, and straighter. A large crop can be depended on, and the product is very attractive in the market, and is a very desirable market gardeners' sort. Pkt. Ioc., $1 / 2$ lb. 20c., I lb. and over 30c. $1 \mathrm{~b}$.

Extra Early Refugee. One of the earliest of the green-podded sorts. Pods are round, fleshy, light green, and medium size. This is an excellent string bean for the early market, and it stands handling well. Pkt. IOc., $1 / 2$ lb. 20c., I lb. and over $30 c$. $1 \mathrm{~b}$.

Late Refugee, or $\mathbf{1 0 0 0}$ to 1 . A standard and very productive sort, highly esteemed for late planting, and is extensively used for canning and pickling. Pods are long, round, light green, and good quality. Pkt. IOc., $1 / 2$ lb. 20c., I lb. and over $30 \mathrm{col}$ lb.

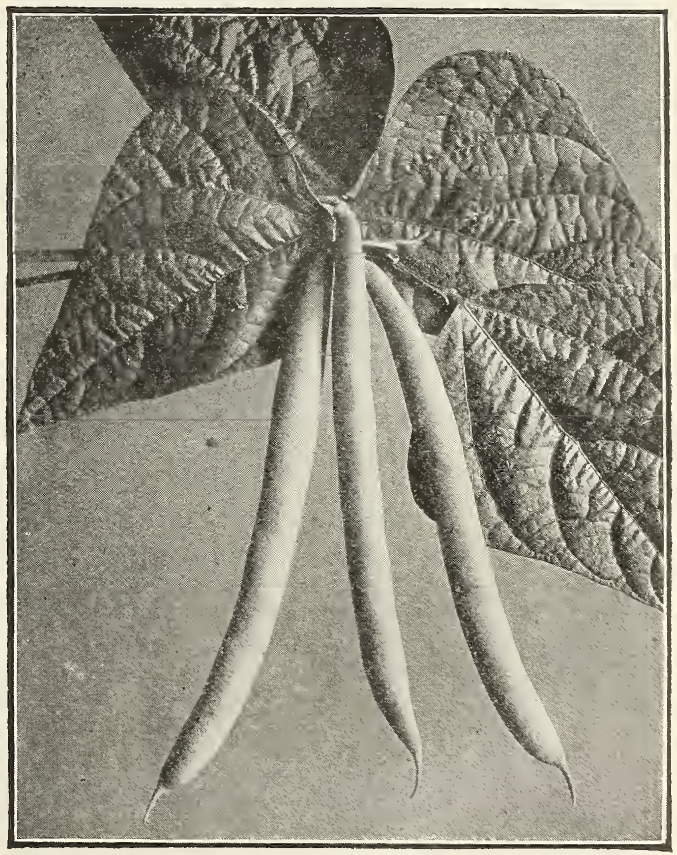

Burpee's Stringless Green Pod Bean 


\section{DWARF, GREEN-PODDED, BUSH, OR SNAP BEANS-Continued}

Bountiful. Vines are vigorous and productive. The pods are very long, straight, broad, flat, and of handsome appearance, and when young, are stringless. They hold tender and brittle much longer than most sorts, and are one of the best for the home, or market garden. Pkt. Ioc., 1/2 lb. 20c., I lb. and over $30 \mathrm{c}$. lb.

Longfellow. Extra long, round, straight pods, very early and productive, tender and of excellent flavor. Pkt. IOc., $1 / 2$ lb. 20c., I lb. and over 30c. lb.

Long Yellow Six Weeks. Early, flat pod; very productive and excellent quality. Pkt. IOc., $1 / 2 \mathrm{lb}$. 20c. I lb. and over 3oc. lb.

Stringless Green Pod (Giant). Very early; round, stringless, full pods. Pkt. IOc., $1 / 2 \mathrm{lb}$. 20c., I lb. and over $30 \mathrm{oc}$. $1 \mathrm{~b}$.

China Red Eye. When young, pods are tender and good quality. Are an excellent shell bean, and when ripe are fine for baking. Pkt. IOc., $1 / 2 \mathrm{lb}$. 20c., I lb. and over 30c. lb.

White Kidney. Field Bean for soup and baking. Pkt. Ioc., 1/2 lb. 20c., I lb. and over 30c. lb.

White Marrow. A white field bean for baking. Pkt. IOc., $1 / 2 \mathrm{lb}$. 20c., I lb. and over 30c. $1 \mathrm{~b}$.

White Navy. A small white field bean for baking. Pkt. IOc., $1 / 2$ lb. 20c., I lb. and over 30c. lb.

Yellow Eye Field. Excellent for baking. Pkt. Ioc. $1 / 2 \mathrm{lb}$. 20c., I lb. and over 30c. lb.

Red Kidney. A very rich flavored baking Bean, shaped like White Kidney but deep red in color. Pkt. IOc., 1/2 lb. 20c., I lb. and over 30c. lb.

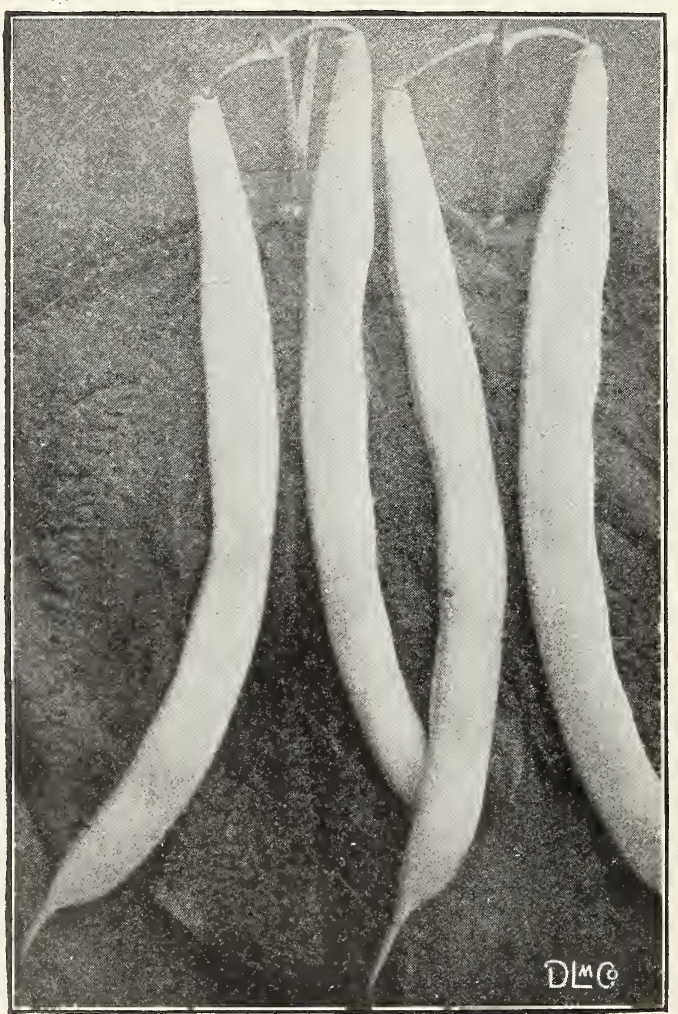

Improved Golden Wax Bean

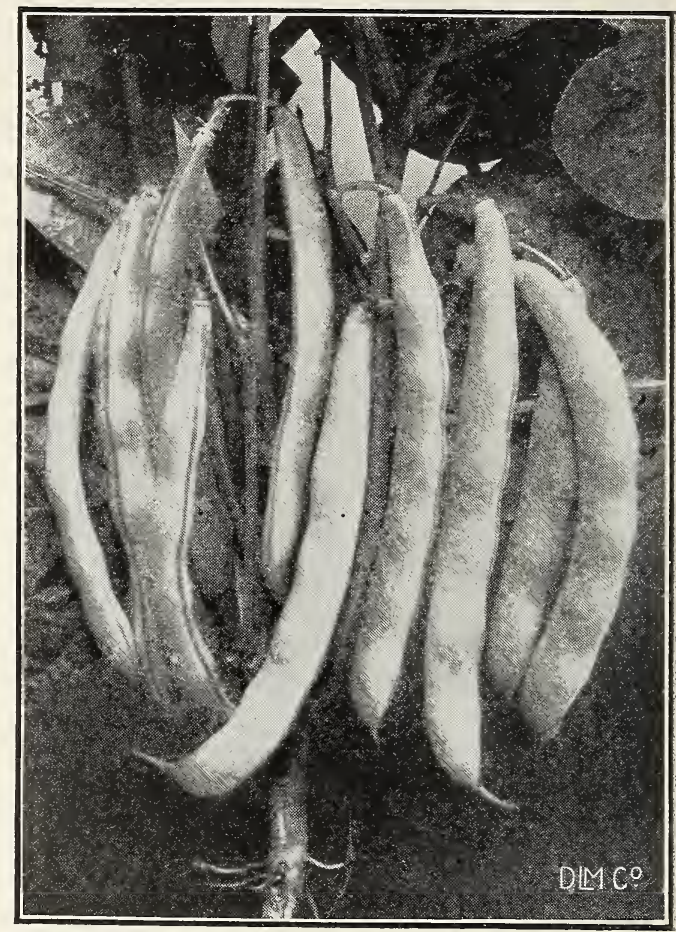

Wardwell's Kidney Wax Bean

\section{Dwarf Wax, Yellow-Podded, or Butter Beans}

If sent by mail, add $5 c$. per lb. for postage.

Hodson Wax. Large, rustless, flat pod. Pkt. IOc., $1 / 2 \mathrm{lb} .20 \mathrm{c}$., Is $\mathrm{lb}$. and over $35 \mathrm{c}$. lb.

Valentine Wax. Extra early; round, meaty pod Pkt. IOc., 1/2 lb. 20c., I lb. and over $35 \mathrm{c}$. lb.

Prolific Black Wax. Early and prolific, pods nearly round; full, stringless and fine quality. Pkt. IOc., $1 / 2 \mathrm{lb}$. 20c., I lb. and over 3oc. lb.

Davis White Kidney Wax. Long, white, waxy, flat pods; very prolific. Pkt. Ioc., $1 / 2$ lb. 20c., I lb. and over $35 \mathrm{c}$. $1 \mathrm{~b}$.

Improved Golden Wax. The most popular standard variety; pods are long, tender and meaty, stringless and rust-proof. Pkt. IOc., 1/2 lb. 20c., I lb. and over 3oc. $1 \mathrm{~b}$.

Currie's Rust-Proof Black Wax. Pods long and flat; excellent quality; early and prolific. Pkt. IOc., $1 / 2 \mathrm{lb}$. 20c., I lb. and over $30 \mathrm{c}$. $1 \mathrm{~b}$.

Wardwell's Kidney Wax. An extremely heavy bearer; pods large and flat, and fine quality. Pkt. IOc., $1 / 2$ lb. 20c., I lb. and over $35 \mathrm{c}$. $1 \mathrm{~b}$.

Round Pod Kidney Wax. A fine, round, long pod. variety, and entirely stringless. Pkt. IOc., $1 / 2 \mathrm{lb}$. 20c., I lb. and over $35 \mathrm{c}$. $1 \mathrm{~b}$.

Golden-Eyed Wax. A very desirable variety; early and prolific; pods flat and free from rust. Pkt. IOc., $1 / 2 \mathrm{lb}$. $20 \mathrm{c}$., I lb. and over $35 \mathrm{c}$. lb.

Refugee Wax. Very early, thick, fleshy, round, stringless, wax-like pods, of fine quality. Pkt. IOc., $1 / 2 \mathrm{lb}$. $20 \mathrm{c}$., I lb. and over $35 \mathrm{c}$. lb.

Sure Crop Wax. Long thick flat pods, string'ess and rustless. Pkt. Ioc., $1 / 2$ lb. $20 \mathrm{c}$., I lb. and over $30 \mathrm{c} .1 \mathrm{~b}$.

Keeney's Rustless Golden Wax. Similar to Imp. Golden Wax. Vines strong and vigorous, and produce an abundance of long, tender, light yellow, wax-like pods, free from rust. Pkt. Ioc., $1 / 2 \mathrm{lb}$. 20c., I $\mathrm{lb}$. and over $30 \mathrm{c}$. $\mathrm{lb}$. 
DWARF WAX, YELLOW-PODDED, or BUT'TER

\section{BEANS-Continued}

Detroit Wax. Vines very hardy and productive Pods light yellow; straight, broad and flat. Tender and rust-proof. Pkt. IOc., $1 / 2$ lb. 20c., I lb. and over 30c. $1 \mathrm{~b}$.

Pencil Pod Wax. Long, round, deep yellow, tender pods; absolutely stringless. Pkt. IOc., 1/2 lb. $20 \mathrm{c}$. I lb. and over 3oc. lb.

Webber Wax. A flat-podded stringless variety vigorous and productive. Pkt. IOc., 1/2 1b. $20 \mathrm{c} .$, I lb. and over 3oc. $1 \mathrm{~b}$.

\section{Dwarf Beans-Varieties for Shelling}

Dwarf Horticultural, or Cranberry. One of the best for shelled beans. When nearly ripe pods are striped and splashed with crimson. Pkt. IOc., 1/2 1b. 20c., I lb. and over 30c. $1 \mathrm{~b}$.

Low's Champion. Very productive; large, green flat pods. Excellent both as a shell bean and string bean. Pods are tender and stringless. As a shell bean rich and fine flavor. Pkt. Ioc., 1/2 1b. 20c., I lb. and over $35 \mathrm{c}$. $1 \mathrm{~b}$.

French Horticultural Dwarf. A new and improved variety. Pods are larger and more beautifully splashed with bright crimson than the ordinary Dwarf Horticultural. Vines sometimes inclined to send out runners, but will not climb a pole; this does not affect the bean in any way. Pkt. Ioc., 1/2 1b. $25 \mathrm{c}$. I lb. and over 40c. $1 \mathrm{~b}$.

Goddard, or Boston Favorite. Similar to Dwarf Horticultural, except beans are longer and pods more highly colored. Pkt. IOc., 1/2 lb. 20c., I lb. and over $30 \mathrm{c}$. $1 \mathrm{~b}$.

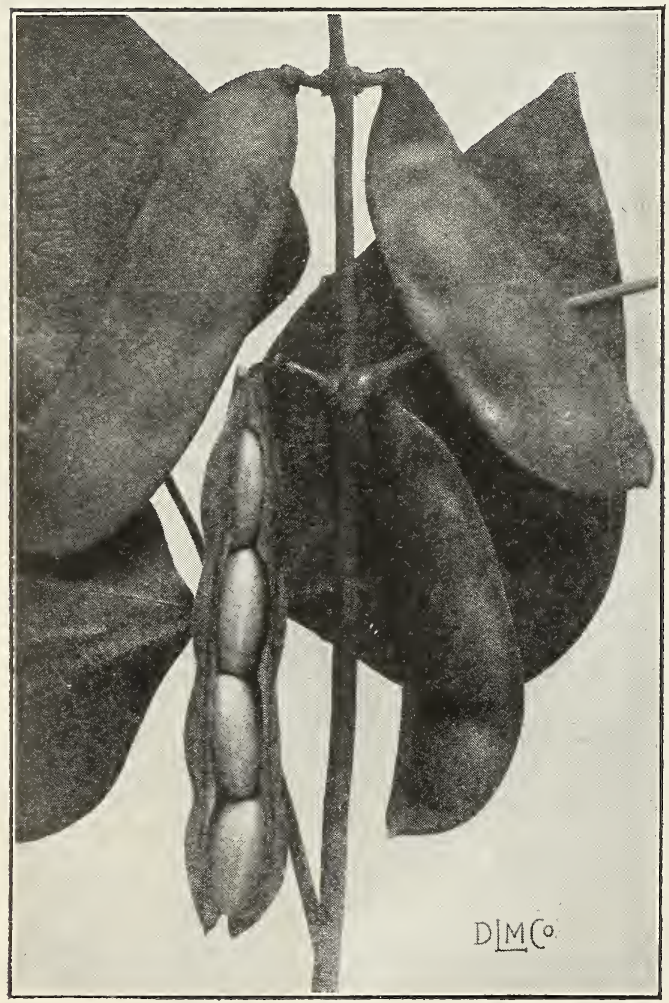

Burpee's Bush Lima Bean

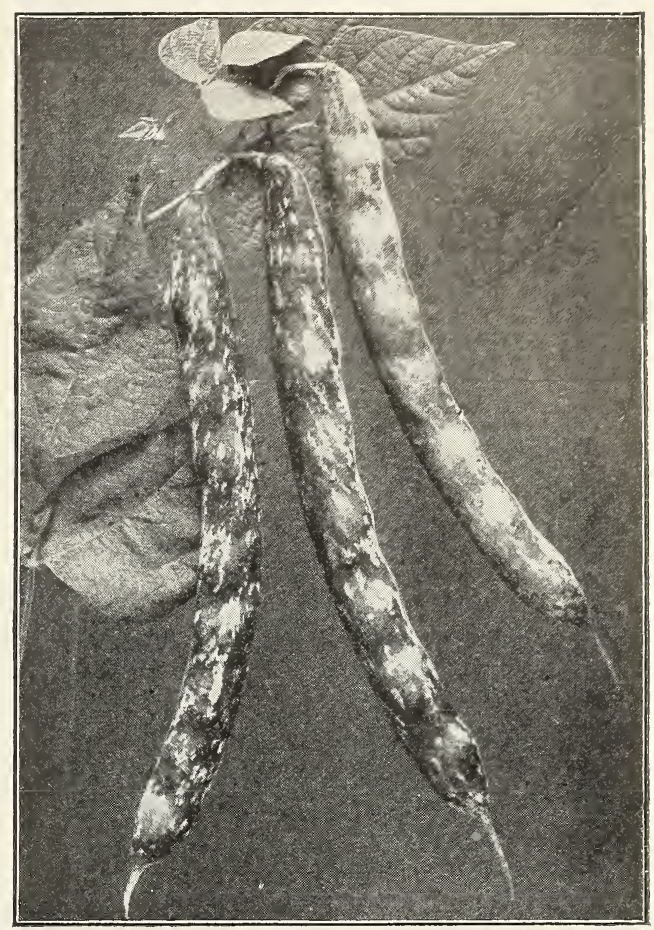

Dwarf Hor ticultural, or Cranberry

\section{Dwarf, or Bush Lima}

Lima Beans are very scarce, especially the Dwarf, or Bush Limas. Our supply is very limited. We advise ordering early.

Culture.-Plant in drills from 2 to 3 feet apart; drop beans about 3 inches apart in the row. Cover about $1 / 2$ inches deep. They can also be planted in hills 3 feet apart one way and 2 feet the other.

Burpee's Bush Lima. A good yielder. Pođs are well filled with large beans, identical in size and luscious flavor to the large pole Beans. Pkt. I $5 \mathrm{c}$., $1 / 2$ lb، 35c., I lb. and over 6oc. $1 \mathrm{~b}$.

Burpee's Improved Bush. Grows more vigorously than the original Burpee's Bush Lima, is earlier, pods are larger, and beans are same flavor and quality as Pole Lima. Pkt. I 5c., $1 / 2$ 1b. 35c., I lb. and over 6oc. $1 \mathrm{~b}$.

Dreer's New Wonder Bush. A fine strain of Dwarf Lima, producing large pods and beans a week earlier than the regular Burpee's Bush, and have same luscious flavor. Pkt. I5c., 1/2 lb. 35c., I lb. and over 6oc. $1 \mathrm{~b}$.

Fordhook Bush Lima. An improved variety of the Dreer's, or Potato class of Limas. The shelled beans are thicker and more blocky in shape, and are of luscious flavor, and are considered by many to be the best of the dwarf Limas. Pods are large and contain 4 or 5 beans. Pkt. I 5c., $1 / 2$ lb. $35 \mathrm{c}$. , I $1 \mathrm{~b}$. and over 6oc. $\mathrm{lb}$.

Henderson's Bush Lima, or Dwarf Sieva. A dwarf form of small, white Lima, early and productive, with small, white, flat beans of luscious flavor. Pkt. I 5c., 1/2 lb. 30c., I lb. and over 50c. $1 \mathrm{~b}$ 


\section{Pole, or Running Varieties}

King Horticultural. Pods and beans are larger than any other type of Horticultural Pole and fully equal in quality. Pods are splashed and striped with crimson. Pkt. IOc., 1/2 lb. 20c., I lb. and over, $35 \mathrm{c}$. $1 \mathrm{~b}$.

White-Seeded Kentucky Wonder. A new pole variety of great merit. Bears long, green, brittle, stringless pods of excellent flavor. It rivals all other pole beans and is destined to become the most popular of all. Pkt. IOc., 1/2 lb. 20c., I lb. and over, 35c. lb.

Kentucky Wonder Wax. An excellent variety, and one of the best pole beans. The pods are long, very thick, meaty, deeply saddlebacked, entirely stringless and bright yellow in color. The vine is thrifty and very prolific. Pkt. Ioc., $1 / 2 \mathrm{lb}$. 20c., I $1 \mathrm{~b}$. and over, $35 \mathrm{c} .1 \mathrm{~b}$.

Early Leviathan Lima. The earliest Pole Lima grown, largesized pod and bean, and very productive. Pkt. I5 c., 1/2 lb. $25 \mathrm{c}$., I $\mathrm{lb}$. and over, $45 \mathrm{c}$. $\mathrm{lb}$.

Large White Lima. The old favorite, and very popular; large podded, luscious beans. Pkt. I $5 \mathrm{c}$., $1 / 2 \mathrm{lb} .25 \mathrm{c}$., I lb. and over, $45 \mathrm{c}$. po 1 .

Siebert's Early Large Lima. One of the earliest Pole Limas. Very vigorous and productive; large, thick pods, and easily opened. Pkt. I5c., 1/2 lb. $25 \mathrm{c}$., I lb. and over, $45 \mathrm{c}$. $1 \mathrm{~b}$.

Early Jersey Lima. A very popular extra early variety. Pods good size and beans of excellent quality. Pkt. I5c., $1 / 2 \mathrm{lb} .25 \mathrm{c}$., I $\mathrm{lb}$. and over, $45 \mathrm{c}$. $1 \mathrm{~b}$.

Carpenteria, Large Lima. A favorite with market gardeners, as it is one of the longest podded and heaviest croppers of all the Pole Limas; beans fat and delicious. Pkt. I 5 c., $1 / 2$ lb. 25 c., I $1 \mathrm{~b}$. and over, $45 \mathrm{c} .1 \mathrm{~b}$.

King of the Garden Lima. A strong grower and uniformly large podded; pods freque ly contain 5 to 6 large beans of excellent quality. Pkt. I $5 \mathrm{c}$., $1 / 2 \mathrm{lb} .25 \mathrm{c}$., I $\mathrm{lb}$. and over, $45 \mathrm{c} .1 \mathrm{~b}$.

Dreer's Improved Lima. Also called Challenger and Potato Lima. Very productive; beans very thick, nearly round, and of excellent quality. Pkt. I 5c., $1 / 2$ lb. $25 \mathrm{c}$., I lb. and over, $45 \mathrm{c} .1 \mathrm{~b}$.

Horticultural, or Cranberry. Very popular; large yielder; beans unsurpassed for quality, pods splashed and striped with crimson. Pkt. IOc., $1 / 2$ lb. 20c., I lb. and over, 35c. $1 \mathrm{~b}$.

Old Homestead, or Kentucky Wonder. Very productive; pods long and hang in clusters from top to bottom of pole; entirely stringless. The best green-podded string bean in cultivation. Pkt. IOc., I/ $1 \mathrm{lb}$. 20c., I lb. and over, $35 \mathrm{c}$. $1 \mathrm{~b}$.

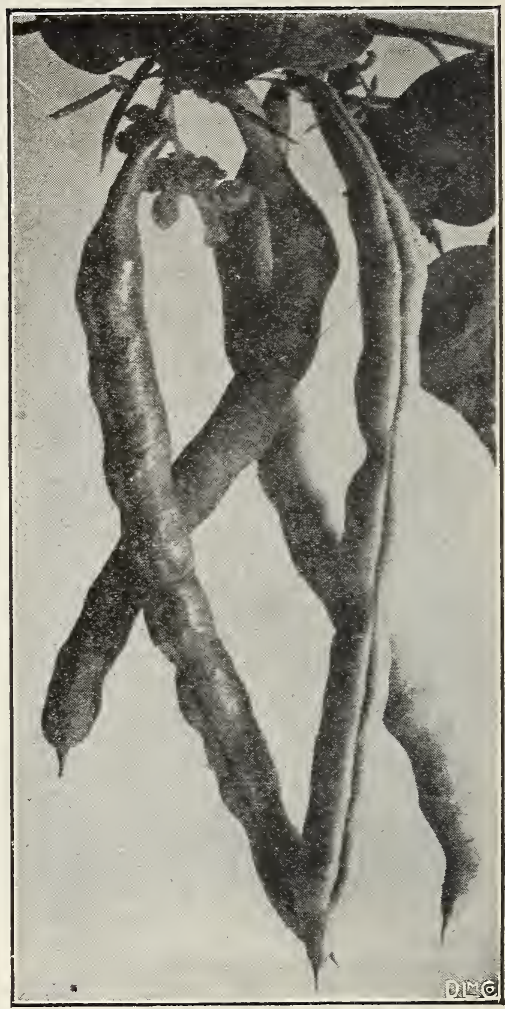

O1d Homestead Pole Bean

Golden Cluster. Wax. This is the best yellow Wax String Bean in cultivation; vines are filled with great clusters of long pods the entire length of pole. Pkt. I 5c., 1/2 1b. 30c., I lb. and over, $50 \mathrm{cc} .1 \mathrm{~b}$.

Lazy Wife. Produces large, stringless pods in great abundance; peculiarly luscious either as string beans or shelling, and are fine baked, when ripe. Pkt. I5c., 1/2 1b. $25 \mathrm{c}$., I lb. and over, $45 \mathrm{c} .1 \mathrm{~b}$.

Dutch Case-Knife. Vines moderately vigorous, climbing well, and excellent for a Corn hill bean. Shellbeans are broad, white, kidney-shaped, early and prolific. Pkt. I 5c., 1/2 1b. 25c., I lb. and over, 45c. 1b.

Scarlet Runners. Ornamental, and an excellent string Bean. Pkt. I $5 \mathrm{c}$., $1 / 2 \mathrm{lb} .25 \mathrm{c}$., I $1 \mathrm{~b}$. and over, $45 \mathrm{c}$. $1 \mathrm{~b}$.

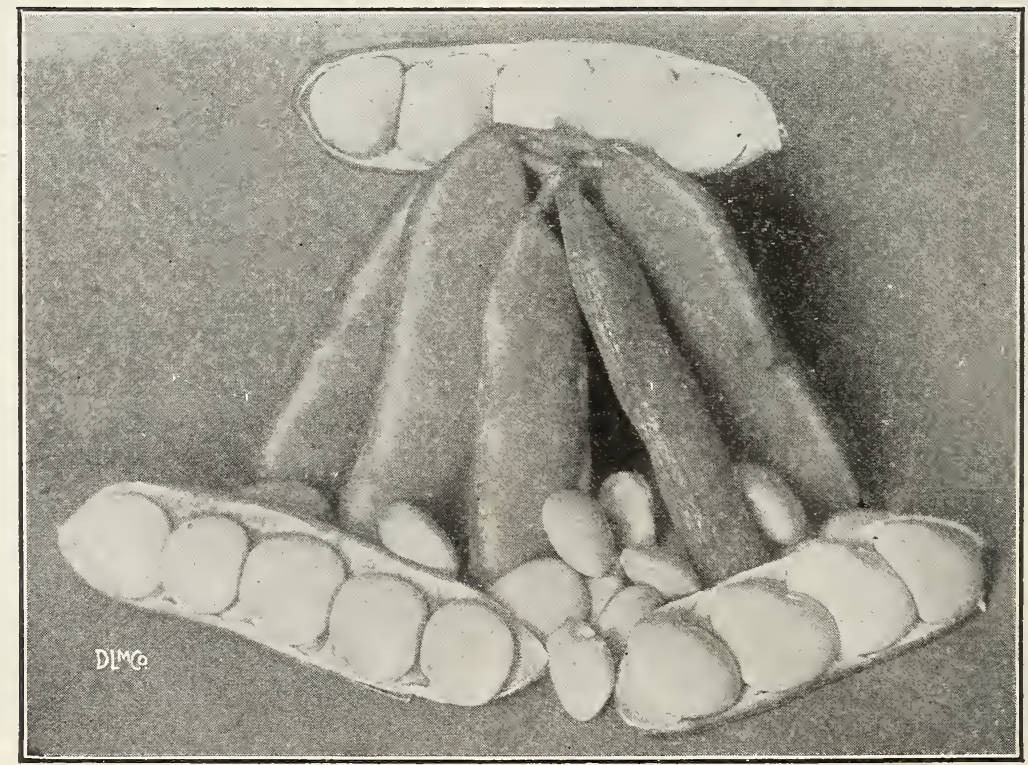

King of the Garden Lima Bean 


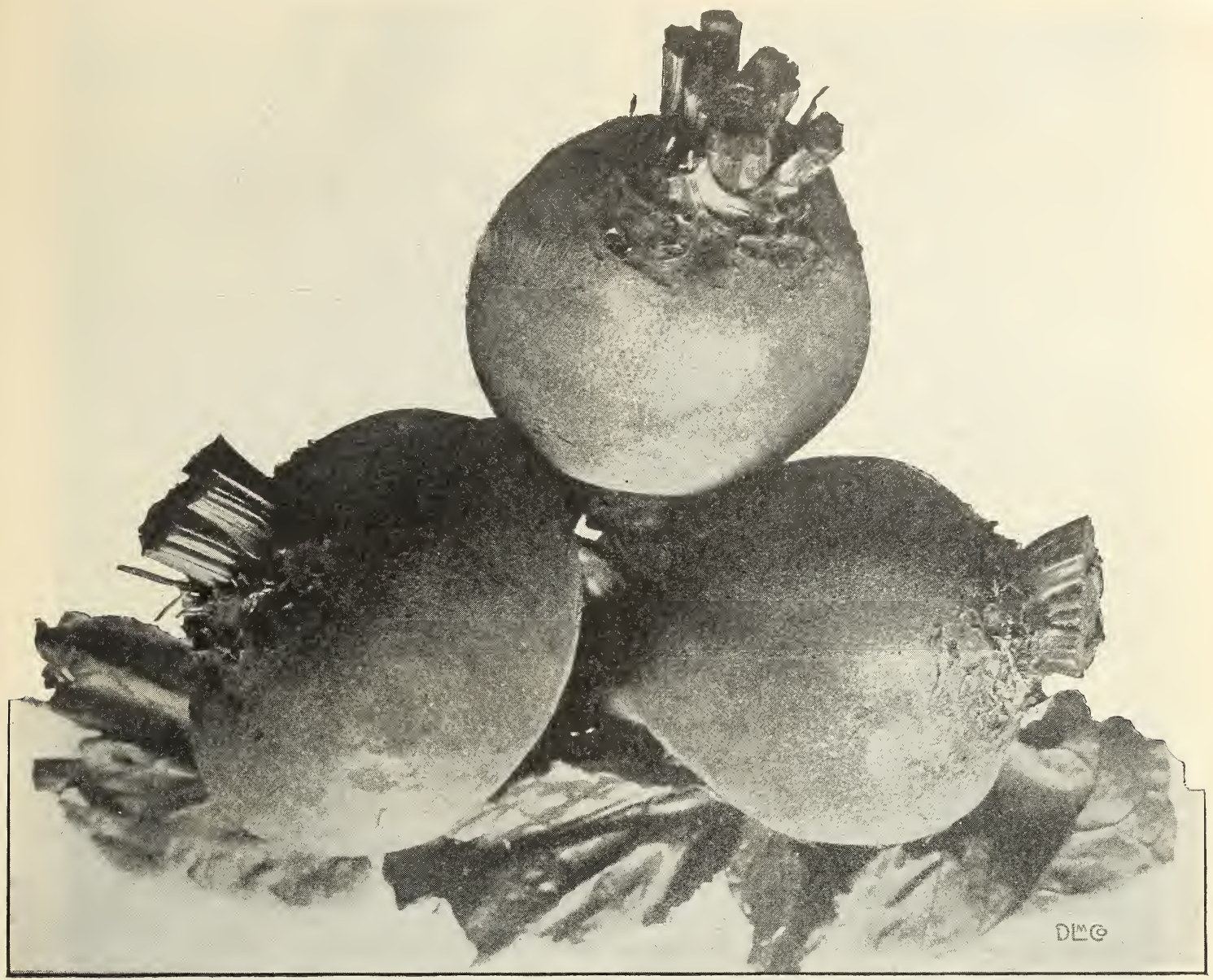

\section{BEETS}

\section{Table Varieties}

These are popular in all gardens, and as a rule are a very profitable crop for market gardeners. Beets fresh from the garden are always more tender and delicious than those that are shipped from a distance, or from a peddler's wagon after they have been bunched for three or four days. They can be sown in succession for different seasons and if too many are produced for table use, make excellent use for poultry and stock.

Culture.-The best results are obtained on a deep, rich, sandy loam. Sow as early as ground can be prepared, in drills, I 4 to I8 inches apart, and thin out to 3 inches in the row. Always sow in freshly prepared soil, which should be pressed firmly over the seed. For Winter use, sow from last of June to last of July.

Sow at the rate of 5 to 6 lbs. to the acre.

Crosby's Egyptian. One of the earliest and best, either for market or the home garden; round, dark red; flesh tender and sweet. Pkt. 5c., oz. Ioc., $1 / 4 \mathrm{lb}$. $25 \mathrm{c} ., \mathrm{lb}$. \$1.00.

Crimson Globe. Early and smooth; fine dark red color; flesh deep crimson, tender and sweet. Pkt. $5 \mathrm{c}$., oz. IOc., $1 / 4$ lb. 25 c., lb. $\$ 1$.00.

Detroit Dark Red. One of the best table varieties, and for canning and pickling. Small, dark red, tender and sweet. Pkt. 5c., oz. Ioc., 1/4 lb. 25c., lb. \$1.0o.

Edmand's Blood Turnip. One of the best for main crop; round, smooth and deep blood red; tender and sweet. Pkt. 5c., Oz. I0c., $1 / 4$ lb. 25c., 1b. \$1.00.
Eclipse. An early, round, dark red variety; very sweet and tender, and one of the best for greens, as the tops seem to be tenderer and richer than other sorts. Pkt. 5c., oz. IOc., 1/4 1b. 25 c., lb. \$1.0o.

Early Blood Turnip. The leading general crop variety; is Turnip-shaped; color deep red; flesh tender and sweet; a good keeper, and desirable for Autumn and Winter. Pkt. 5c., oz. Ioc., 1/4 lb. 25c., 1b. \$I.0o.

Long Dark Red. Long, very dark red, sweet and tender; stands dry weather well, and is a good Winter keeper. Pkt, 5c., oz. IOc., 1/4 1b, $25 \mathrm{c}, 1 \mathrm{~b}, \$ \mathrm{I} .00$. 


\section{BEETS-Continued}

Extra Early Egyptian. A rather flat variety; very dark red, and popular for forcing purposes. Pkt. 5c., oz. I Oc., $1 / 4$ lb. $25 \mathrm{c}$., lb. \$I.oo.

Dewing's Early Blood. Deep red color, smooth and fine form; one of the leading sorts for market and family garden. Pkt. 5c., oz. Ioc., 1/4 lb. 25c., lb. \$I.OO.

Lentz Blood Turnip. Is a large, dark red, main crop variety; very profitable for market and home garden. Pkt. 5c., Oz. IOc., 1/4 lb. 25c., lb. \$1.00.

Arlington Imp. Blood Turnip. Early, round, dark red, medium size; very tender and sweet. Pkt. 5c., oz. IOc., $1 / 4$ lb. 25c., lb. $\$$ I.00.

Early Model. A new variety. Is a perfect globe in shape; dark red in color and uniform in size. Pkt. 5c., oz. roc., $1 / 4$ lb. 25 c., lb. \$1.0o.

Early Bassano. An early, quick-growing variety, excellent for the table, and especially adapted for use as greens. Pkt. 5c., Oz. Ioc., $1 / 4$ lb. 25c., 1b. $\$$ I.00.

Half-Long Dark Blood. Excellent for Winter and Spring use. The flesh is rich, dark red, very sweet, crisp and tender. Good for slicing for pickles. Pkt. 5c., Oz. Ioc., $1 / 4$ lb. 25 c., lb. $\$$ I.00.

South Coventry, Conn., March 10, 1919.

"Enclosed find order for seeds which I would like to have shipped by express, C. O. D. about April 1.

I planted your seeds last year and was well satisfied with them and am digging Parsnips now and the best I ever had."

Yours very truly,

H. E. H.

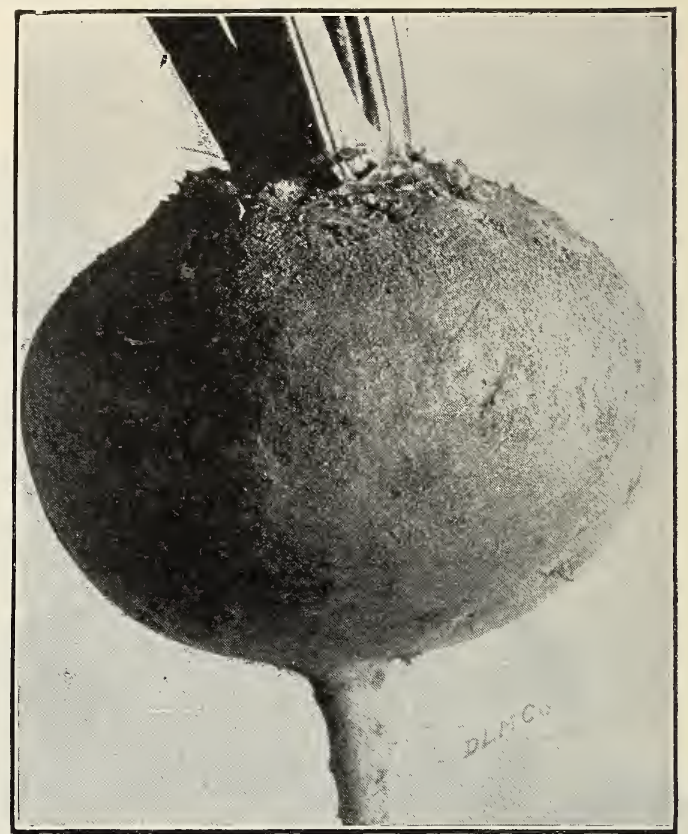

Eclipse Beet

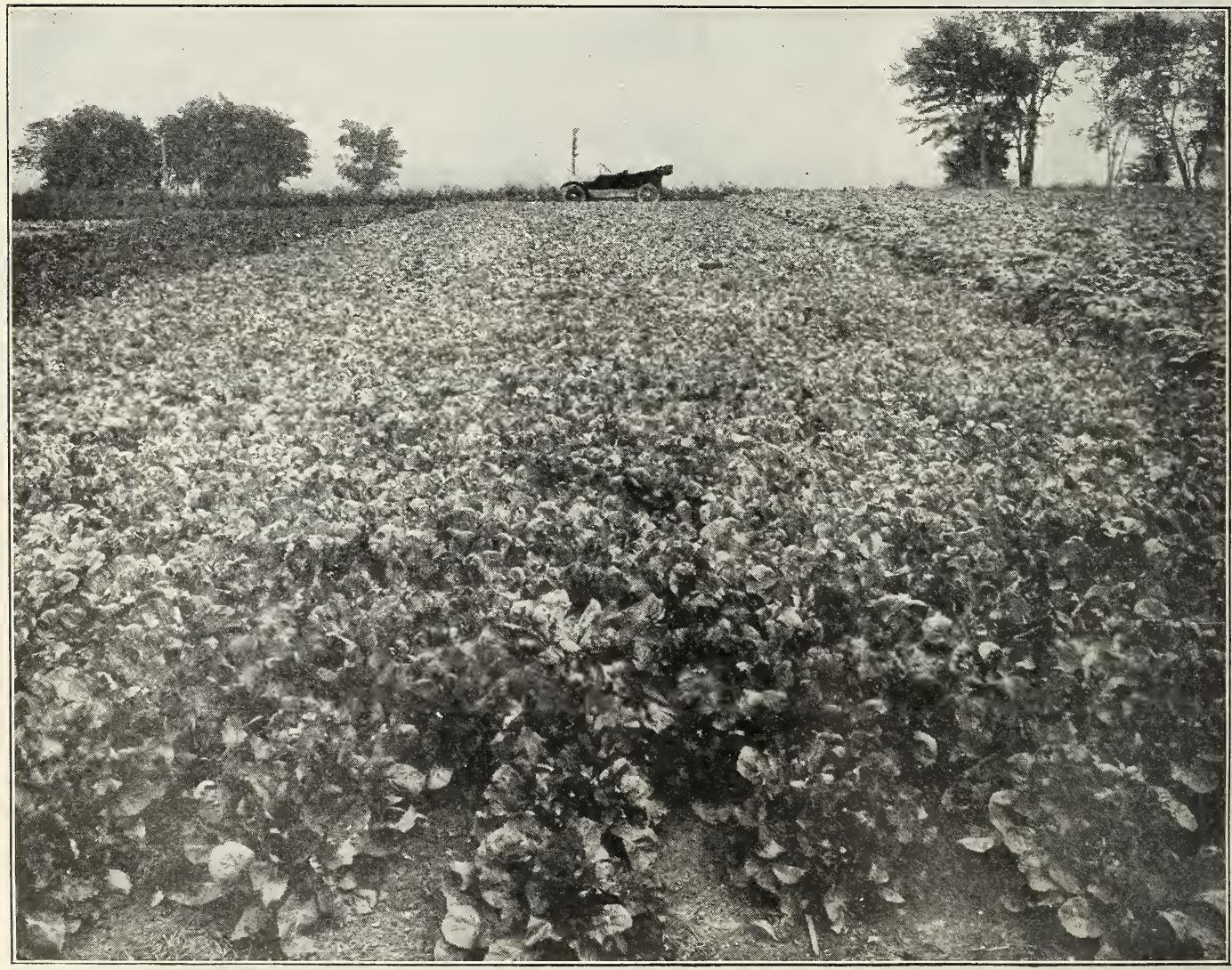

A partial vi zw of a vegetable garden, belonging to Mr. Anders Christensen, an "up-to-date" Market Gardener of Wilson, near Hartford, Conn. In the foreground is a field of Early Crosby's Egyptian Beet. Mr. Christensen always buys Hart's seeds 


\section{Mangel and Sugar Beets for Stock}

Culture.-Both Mangels and Sugar Beets require deep, well enriched soil. Sow in May or June, in rows $21 / 2$ feet apart, and thin to 8 or Io inches in the row.

5 or 6 lbs. of seed required to the acre.

Note.-The value of Mangels and Sugar Beets for stock feeding is clearly seen in the improved health and condition of animals, the increased flow and quality of milk from cows, and the saving in fodder. Everyone who keeps even one cow should grow a patch of either Mangels or Sugar Beets for Winter feed.

Giant Long Red. Largest of all the Mangels and heaviest cropper. Pkt. $5 \mathrm{c}$., oz. IOc., $1 / 4 \mathrm{lb}$. $25 \mathrm{c}$. $1 \mathrm{~b}$. $80 \mathrm{c}$.

Golden Tankard. Very heavy cropper; skin and flesh a deep yellow color, and good milk producing qualities. Pkt. 5c., Oz. IOc., $1 / 4$ lb. $25 \mathrm{c}$., 1b. $80 \mathrm{c}$.

Yellow Globe. Well adapted for shallow soils, and more easily pulled. Yields well, and is an excellent keeper. Pkt. 5c., Oz. IOc., $1 / 4$ lb. $25 \mathrm{c}$., lb. 8 oc.

Long Yellow. A fine yellow Mangel; heavy cropper and a good milk producer. Pkt. 5c., oz. IOc., $1 / 4 \mathrm{lb}$. $25 \mathrm{c}$, $1 \mathrm{~b}$. $80 \mathrm{c}$.

Improved White Sugar. One of the best stock feeding Beets. It is claimed by many dairy farmers that Sugar Beets produce more and better quality milk than Mangels. Pkt. $5 \mathrm{c}$., Oz. IOc., $1 / 4$ lb. $25 \mathrm{c}$., lb. \$1.00.

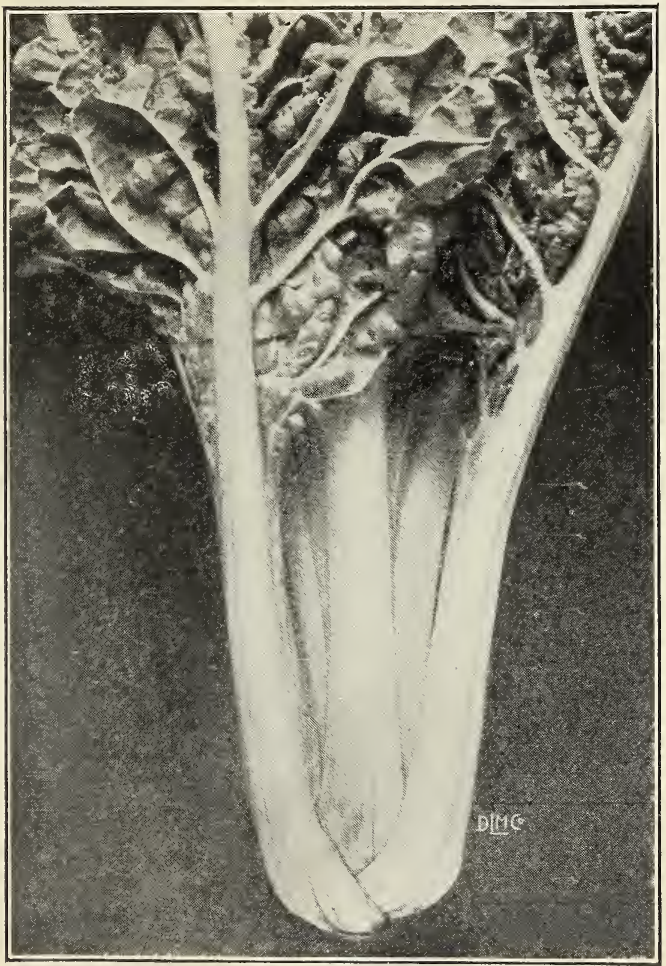

Lucullus Swiss Chard

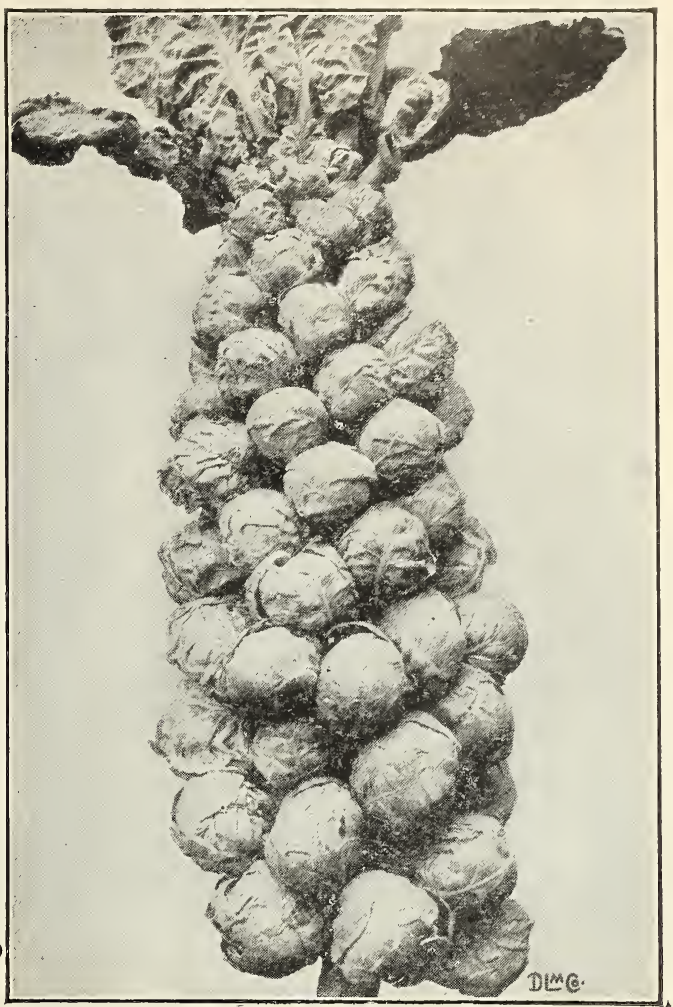

Brussels Sprouts

\section{Beet for Sugar}

Klein Wanzleben. One of the best for sugar making, and extensively planted for Sugar factories. Pkt. 5 c., Oz. IOc., $1 / 4$ lb. 25 c., lb. and over $\$$ I.oo.

\section{BRUSSELS SPROUTS}

The plants are very hardy, and grow from 2 to 3 feet high, bearing a large mass of leaves at the top. The sides of the main stem are covered with small Cabbage heads, which are broken off and cooked the same as Cabbage.

Improved Half Dwarf. The standard variety. Pkt. 5c., oz. 20 c., $1 / 4$ lb. 75 c., lb. $\$ 3.00$.

\section{SWISS CHARD}

The Chard Beet is grown for the tops, which are superior to common Beet for greens, and are also fine for feeding to chickens.

Swiss Chard, or Silver Beet. This variety has large, thick, plain, pale green leaves. Plit. 5c., oz. Ioc., $1 / 4$ lb. 25 c., lb. $\$$ I.00.

Green Curled Chard. Large stalk with green curled leaves. Pkt. 5c., Oz. Ioc., $1 / 4$ lb. $25 \mathrm{c}$., lb. $\$ 1.00$.

Lucullus. A variety of special merit, as two different dishes can be prepared from a single plant. The stalks are thick and broad, and are prepared and served in the same manner as Asparagus. The leaves are used for greens, and are considered by many as superior to Spinach. Pkt. 5c., Oz. IOc., $1 / 4$ lb. $25 \mathrm{c}$., lb. $\$$ I.0o.

We very strongly recommend growing Sugar Beets and Mangels for Stock. Special prices for large quantities. 


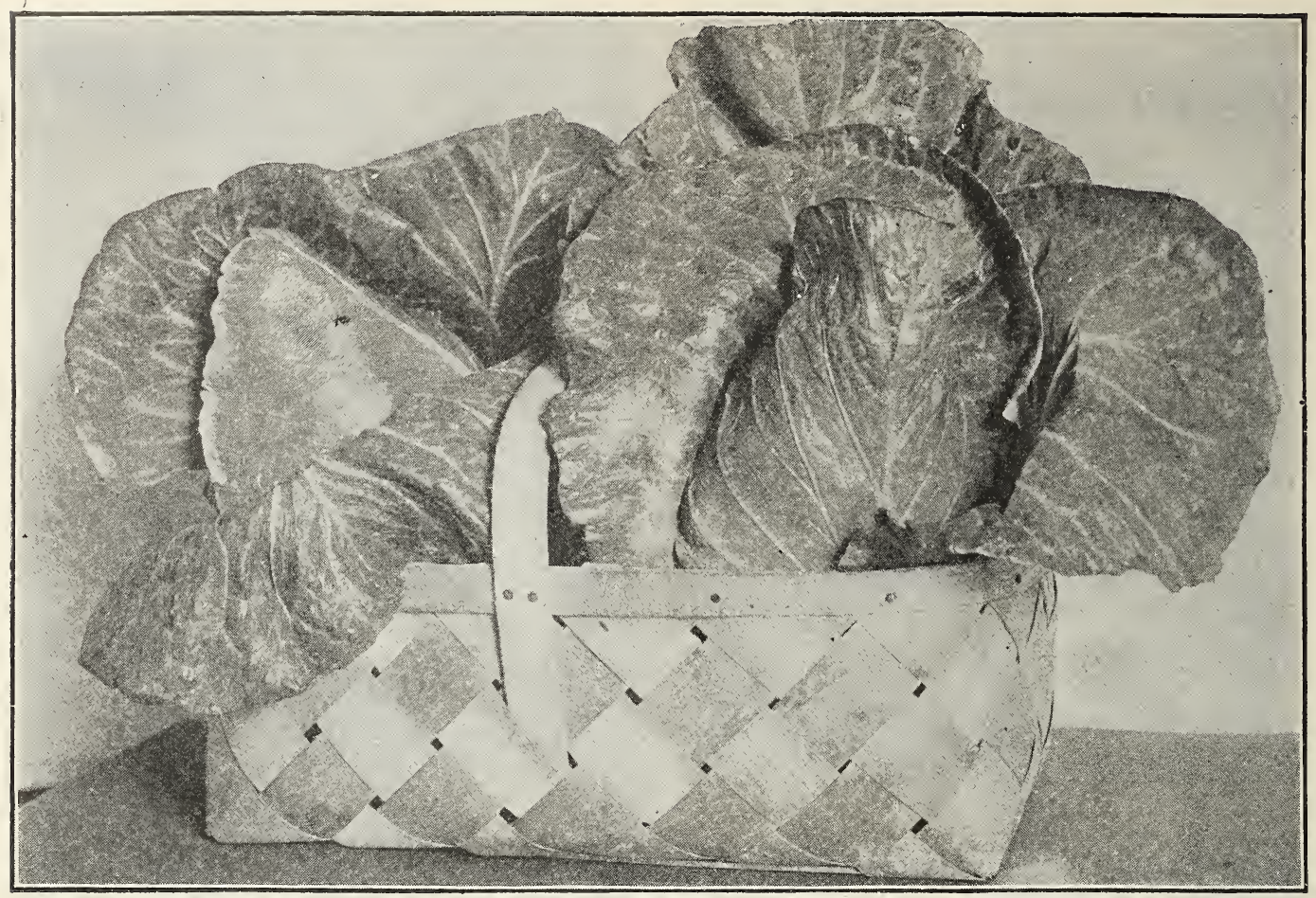

Early Jersey Wakefield Cabbage

\section{CABBAGE}

Culture.-To grow Cabbage successfully the ground must be highly manured and thoroughly worked. For very early plants, the seed is often sown last of September, and protected in coldframes through the Winter. But the more common way is to sow in hotbeds in February or March, and while plants are very small, prick them out into coldframes to be transplanted later, when danger of frost is past. For late crops sow in May. Set plants in rows 2 to $2 \frac{1}{2}$ feet apart, and 18 inches in the row.

One ounce of seed will produce about 2000 plants.

Copenhagen Market. New Early Danish Cabbage. Large, round, solid heads. As early as Jersey Wakefield, and being larger, yields more in a given space. Pkt. IOc., oz. 40c., $1 / 4$ lb. $\$$ I.30, lb. $\$ 5.00$.

Early Jersey Wakefield. One of the earliest and best of the pointed head varieties. Pkt. 5c., oz. $25 \mathrm{c}$. $1 / 4$ lb. 80 . 1b. $\$ 3.00$.

Early Winnigstadt. A very desirable pointed head sort. Pkt. 5c., oz. $25 \mathrm{c}$., $1 / 4$ lb. 8 oc., lb. \$3.00.

Early Spring. An extra early flat head variety. Pkt. 5c. Oz. 25 c., $1 / 4$ lb. 80 c., lb. $\$ 3.00$.

Enkhuizen Glory. A valuable early variety, producing, large solid heads of very compact growth, which permits close planting, thus increasing the yield of a given area. Pkt. IOc., oz. 40c., $1 / 4$ lb. \$I.30, lb. \$5.00.

Large Charleston Wakefield. Same type as Jersey Wakefield, but heads are considerably larger, and is a week later. Pkt. 5c., oz. 25c., $1 / 4$ lb. 80c., lb. $\$ 3.00$.

All-Head Early. One of the earliest of the flat-headed varieties. Is good for both Summer and Autumn. Pkt. 5c., oz. 25c., $1 / 4$ lb. 80 c., lb. $\$ 3.00$.

Succession. A second early, flat head variety, and for a medium early, main crop, or late use, has no superior. Pkt. 5c., oz. 25c., 1/4 lb. 80c., lb. \$3.00.

Hencierson's Early Summer. A desirable early large flat head variety. A good keeper and does well in Summer and Autumn. Pkt. 5c., Oz. 25c., $1 / 4 \mathrm{lb}$. 80c., 1b. $\$ 3.00$.

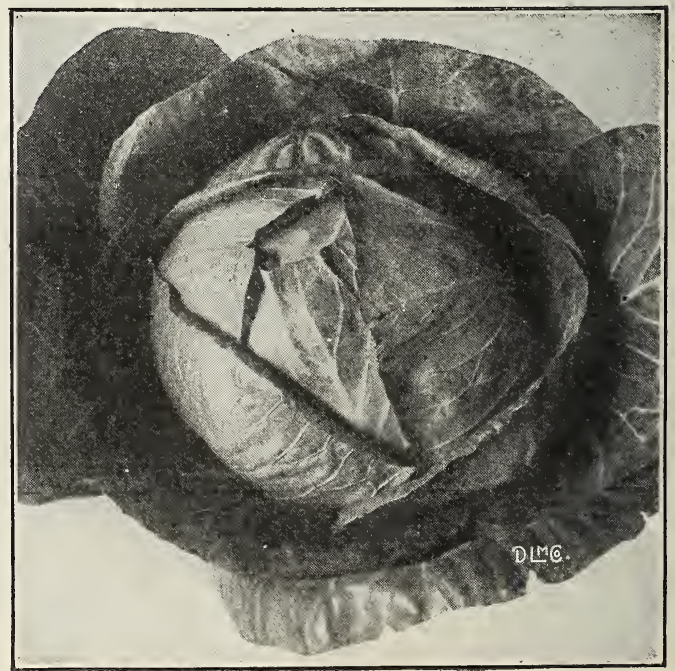

Copenhagen Market Cabbage 


\section{CABBAGE-Continued}

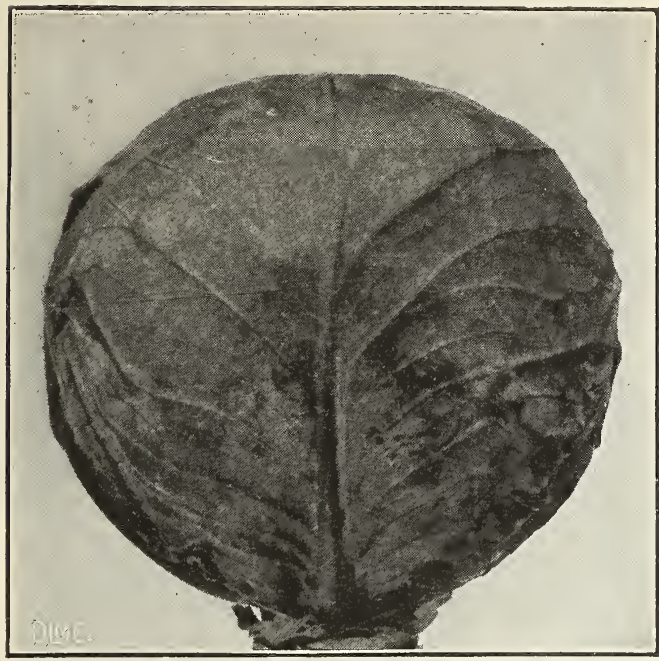

Danish Ball Head Cabbage

Danish Ball Head. The great Winter keeper. Heads very heavy, globe-shaped, and keeping qualities unsurpassed. Pkt. I oc., oz. $40 \mathrm{O} ., 1 / 4$ lb. $\$$ I.30, lb. $\$ 5.00$.

Danish Round-Head. Similar to Danish Ball-Head. but grows more compact. Heads are extremely hard and solid. One of the best keeping varieties. Pkt. IOc., oz. 40c., $1 / 4$ lb. $\$$ I.30, lb. $\$ 5.00$.

Fottler's Improved Brunswick. A very low-growing, flat-head variety; large and solid, and a desirable intermediate or late sort. Pkt. $5 \mathrm{c} ., 0 z .25 \mathrm{c} ., 1 / 4 \mathrm{lb}$. $80 \mathrm{c} ., \mathrm{lb} . \$ 3.00$.

Surehead. A large, late, flat-headed sort; hard and firm. Pkt. 5c.. Oz. 25c., $1 / 4$ lb. 80 c., 1b. $\$ 3.00$.

Premium Late Flat Dutch. A very popular standard variety. Its keeping qualities are unsurpassed heads large, tender and fine flavored. Pkt. $5 \mathrm{c} ., \mathrm{oz}$ 25 c., $1 / 4$ lb. 80c., I lb. $\$ 3.00$.

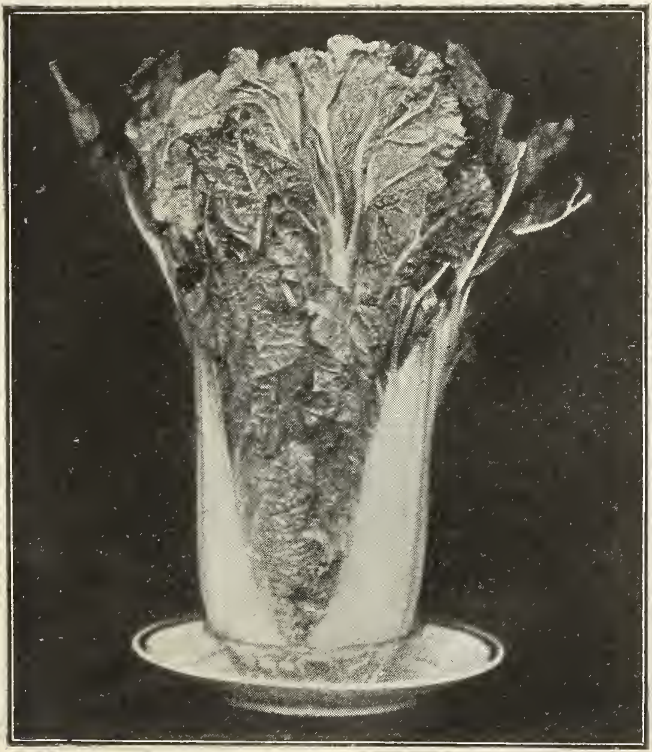

Chinese, or Celery Cabbage Paoting
Warren's Stone Mason. A very solid and hard, late, flat head. Pkt. 5c., oz. $25 \mathrm{c}$., $1 / 4$ lb. $80 \mathrm{c}$., 1b. $\$ 3.00$.

Perfection Drumhead Savoy. Large, solid heads; sweet and tender; leaves curled and crumpled. Pkt. 5c., oz. 25 c., $1 / 4$ lb. 80 c., lb. $\$ 3.00$.

Mammoth Red Rock. Excellent for pickling. Head round and hard, and dark red color. Pkt. Ioc., oz. $35 \mathrm{c} ., 1 / 4 \mathrm{lb}$. $\$$ I. $25, \mathrm{lb} . \$ 4.00$.

All Seasons. One of the finest of the second early sorts. The heads are hard and solid, and flattened on top. It is called All Seasons because it is as good for Autumn and Winter as for early Summer Pkt. 5c., oz. 25c., 1/4 lb. 8oc., lb. $\$ 3.00$.

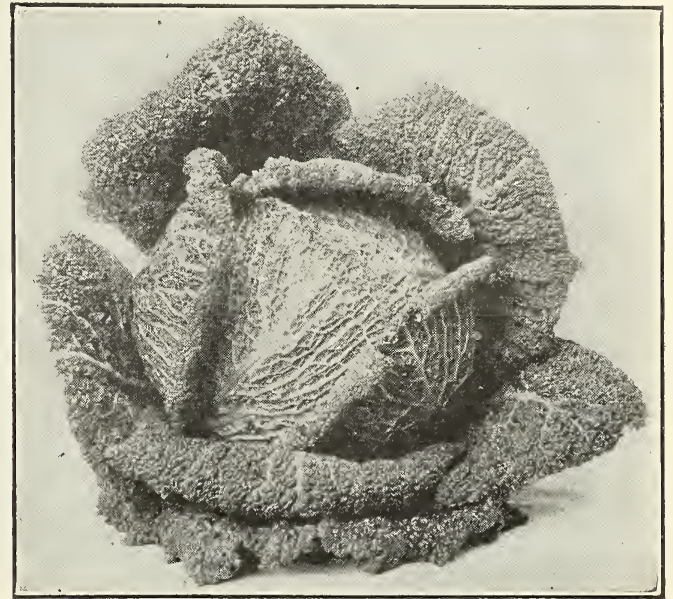

Perfection Drumhead Savoy Cabbage

\section{Chinese, or Celery Cabbage}

(Pe-Tsai)

This exceptionally fine vegetable is of the Cabbage family from China, and possesses striking characteristics which place it in a class by itself. Its fine quality, and attractive appearance, makes it a good seller.

Grows like Cos-Lettuce and when its outer leaves are stripped off shows a picture of Lettuce and Celery combined. Shredded it makes the finest slaw, and stripped of its mid-ribs which-are eatem as Celery, it makes a fine salad, or it may be cooked like Asparagus. It possesses a very mild and pleasant flavor.

Sow the seed like regular Cabbage. If for early planting sow in hotbeds in February or March; if for later planting, sow early in July. It will mature I2 to 5 weeks from time of sowing seed, and will not stand frost.

Paoting. Big, compact, tender and crisp, and one of the best for the early Summer months, but does well all the season. It is vigorous, and free from insects. Pkt. roc., oz. 40c., 1/4 lb. \$I.30, lb. \$5.00.

Peking. Very large and compact, tender and crisp, and is considered one of the best for late Fall and Winter. It is a good keeper, and very attractive appearance. Pkt. I0c., oz. 40c., 1/4 lb. $\$$ I.30, 1b. $\$ 5.00$ 


\section{CARROT}

Culture.-Like all root crops, a rich, deeply. cultivated soil that has been well manured for some previous crop, is most suitable for Carrot. Newly manured ground has a tendency to produce forked roots. For early crops sow as early as ground can be worked, and for later crops sow up to the first of June. Sow in rows I 4 inches apart, and cover not over $1 / 2$ inch, and thin to 3 inches in the row.

An ounce will sow too feet of drill (3 to 4 lbs. to an acre.)

Chantenay. A very desirable and popular variety, and makes a fine bunching sort; stump-rooted; 5 to 6 inches long. Pkt. 5c., oz. I oc., 1/4 1b. 25c., lb. \$I.0o.

Danvers Half-Long Stump-Root. The best variety for general purposes, and the most largely used, both for stock feeding and table use. Pkt. 5c., oz. IOc., $1 / 4$ lb. 25c., lb. \$I.0o.

Early Scarlet Horn. A good, short variety for table use. Pkt. 5c., oz. Ioc., 1/4 lb. $25 \mathrm{c}$., lb. \$I.0o.

Rubicon. This is a new and distinct American strain, finely shaped, and of a deep orange color. It is early, half-long, stump-ending, and excellent for growing under glass, or outside at any season of the year. Pkt. 5c., oz. I Oc., $1 / 4$ lb. $25 \mathrm{c}$., lb. $\$$ I.oo.

Oxheart, or Guerande. One of the best croppers among the short Carrots, and is very desirable for heavy soils. Stump-rooted and about 4 inches long. Pkt. 5c., Oz. IOc., 1/4 lb. 25c., 1b. $\$$ I.00.

St. Valery, or Intermediate. Scarlet, half-long variety; broad at the shoulder and tapering to a point. Good general cropper. Pkt. 5c., oz. IOc., $1 / 4$ lb. 25 c., 1b. \$I.0o.

Improved Long Orange. The standard long variety for garden or field crops. A very heavy yielder. Pkt. 5c., Oz. IOc., $1 / 4$ lb. 25 c., lb. \$I.0o.

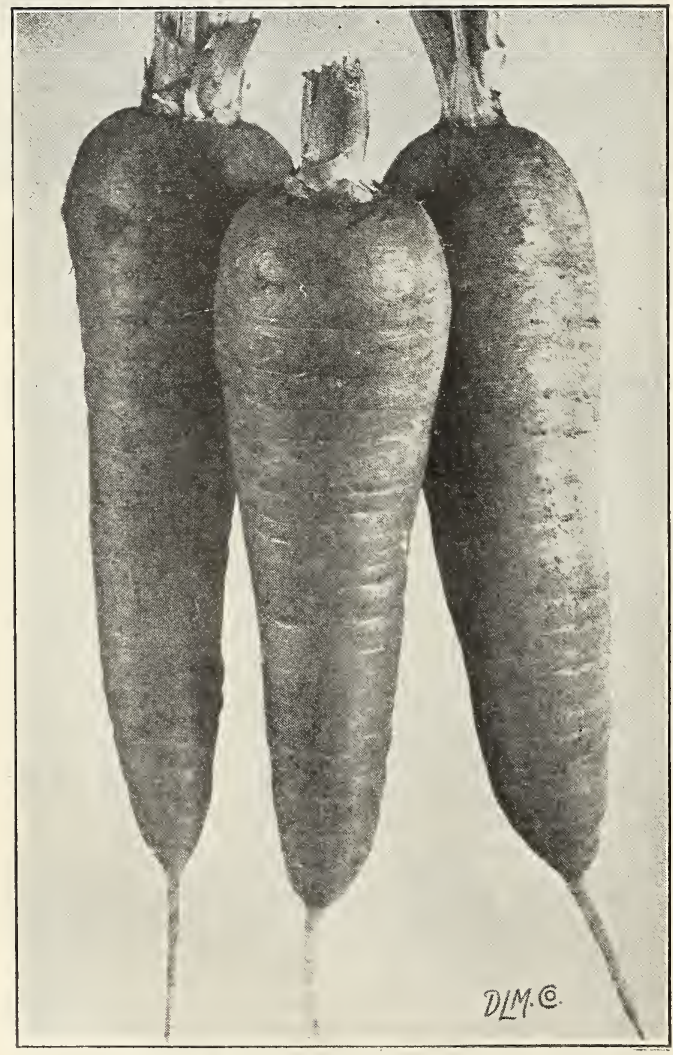

Danvers Half-Long Stump-Rooted Carrot

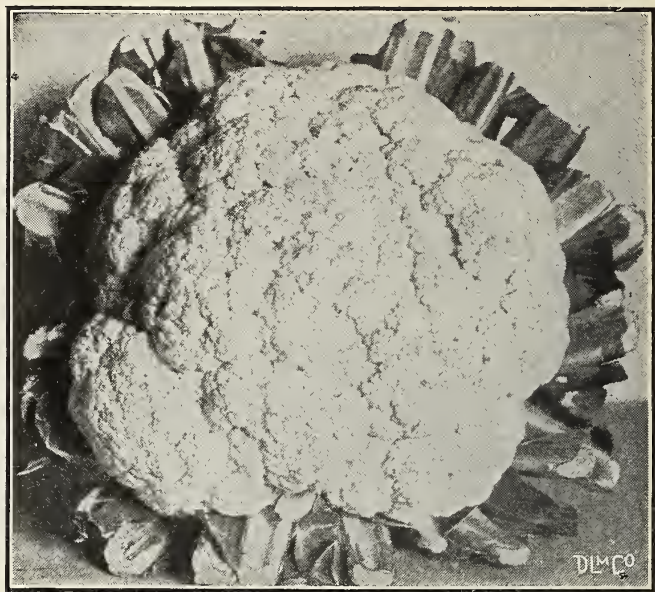

Early Snowball Cauliflower

\section{CAULIFLOWER}

Culture.-The culture of Cauliflower is much the same as that of Cabbage. The soil should be made rich, and be thoroughly cultivated. Sow seed in hotbed early in March, and when sufficiently large, transplant in coldframes, and gradually harden by exposure. As early as weather will permit, set in the open ground, in rows 3 feet apart, and 2 feet in the row. For late Fall crops, sow at same time and treat in same manner as for late Cabbage. Cauliflower will not head in hot, dry weather; therefore, planting should be regulated so they will head either in early Summer or Autumn. Keep well watered when they begin to head. If the leaves are drawn up and tied loosely over the head, it will hasten blanching.

One ounce will produce about 2000 plants

Early Snowball. The best and most popular early dwarf variety grown, producing large, white, solid heads, and a sure header. Pkt. I 5 c., Oz. $\$ 2.25,1 / 4 \mathrm{lb}$. $\$ 9.00$.

Early Dwarf Erfurt. An early variety, forming good, solid, white heads. Pkt. I5 c., oz. \$I.75, 1/4 lb. \$6.50.

Autumn Giant. A valuable late variety; heads are large, white and solid, and remain a long time fit for use. Pkt. IOc., Oz. 50c., $1 / 4$ lb. $\$$ I. 75 .

Extra Early Paris. The most dwarf and earliest heading of all. Heads are solid, but rather smaller than the Erfurt type. Pkt. Ioc., oz. 6oc., $1 / 4$ lb. $\$ 2.00$.

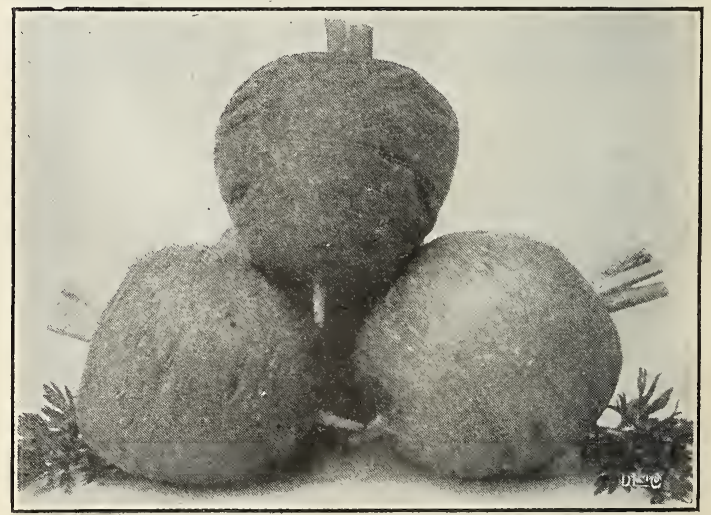

Ox Heart, or Guerande 


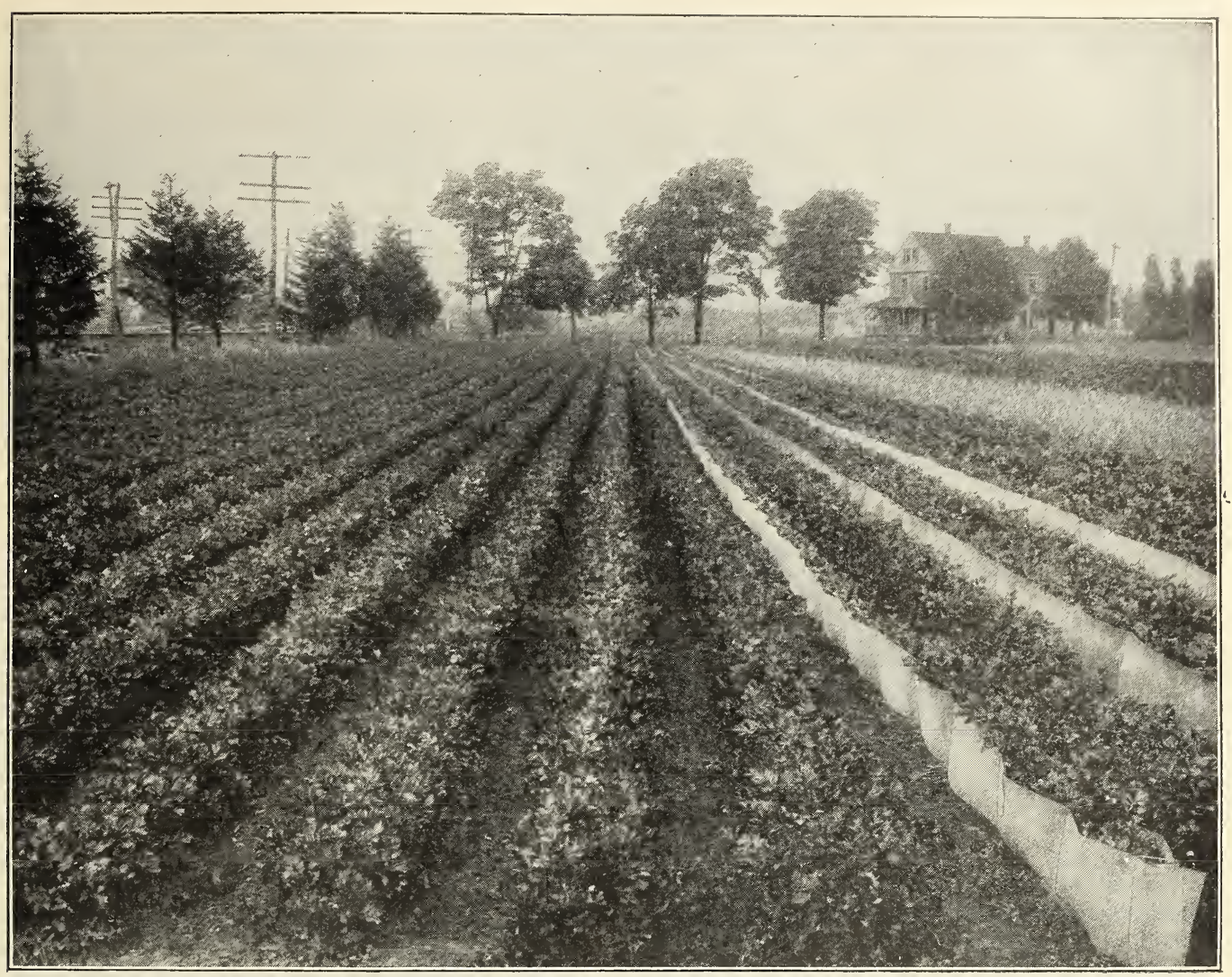

Another view of Mr. Anders Christensen's Gardens-Bleaching Paris Golden Celery for early market

\section{CELERY}

Culture.-Sow the seed in the open ground as early as ground can be worked. The seed is slow to germinate and should be firmed into the soil rather than covered, and the soil where it is planted should be kept moist. If seed is sown in rows where it is intended to remain, the plants should be thinned out when 3 or 4 inches high, to 5 or 6 inches apart, and plants taken up may be transplanted. When transplanting clip off the tops and the ends of the roots to make the plants stocky. Rows should be 4 or 5 feet apart, and plants 5 or 6 inches apart in the row. After planting is completed cultivate frequently. About the middle of August begin to draw the earth up to the plants to blanch or whiten them. Continue hilling or banking them at intervals until cold weather, when they should be taken up and put in a pit or cellar for Winter use. To get very early plants, seed should be started in boxes or hotbeds, and if grown too large before time to set them out in the open, clip off the tops to make them grow stocky.

\section{An ounce of seed will produce 3000 plants.}

Paris Golden, French Grown. The most popular market variety, especially for early crop. It is golden yellow, both stem and leaves, and unlike any other variety, and unless the seed is French grown will not produce the best results. (Our seed is imported direct from the grower.) Pkt. IOc., oz. 6oc., $1 / 4$ lb. $\$ 2.25$, lb. $\$ 9.00$.

Golden Self-Blanching, American Grown. The most popular American variety in use, both as an early and main crop. The plant is naturally golden yellow, but needs to be blanched to make it brittle and fit for table use. Pkt. 5c., oz. 20c., 1/4 lb. 75c., lb. $\$ 3.00$.

Golden Hearted. A very popular Winter variety. Pkt. 5c., oz. I5c., $1 / 4$ lb. 40c., lb. \$I.25.

Giant White Solid. Large, solid, pure white stalks of fine appearance and flavor when properly blanched. A good Winter variety. Pkt. 5c., oz. I5 c., $1 / 4 \mathrm{lb}$. 40c., lb. $\$ 1.25$.
Boston Market. Solid green stalks, blanching white. Pkt. 5c., oz. I5 c., 1/4 lb. 40c., lb. \$1.25.

Celeriac, or Turnip-Rooted. Produces Turnip-like roots which keep well for Winter use. It is highly esteemed either cooked for flavoring soup, or sliced and used as a salad. Pkt. 5c., oz. I5C., 1/4 lb. 50c., lb. $\$$ I.75.

Columbia. A fine second early sort, of stocky growth with broad, heavy stalks; crisp, nutty flavor, easily blanched. Pkt. 5c., oz. I 5c., $1 / 4$ lb. 40c., lb. \$1.25.

Giant Pascal. A large, long-keeping Winter variety; crisp and fine flavor. Pkt. $5 \mathrm{c}$., oz. I $5 \mathrm{C} ., 1 / 4 \mathrm{lb}$. 40c., 1b. \$1.25.

Winter Queen. A fine Winter variety; grows large, and is of fine flavor. Pkt. 5c., oz. I5 ., 1/4 lb. 40c., lb. $\$$ I.25.

White Plume. A very desirable, early variety, that can be blanched for use early in the Fall; tender and fine flavor. Pkt. 5c., Oz. I5 ., 1/4 lb. 40c., ib. $\$ 1.25$. 


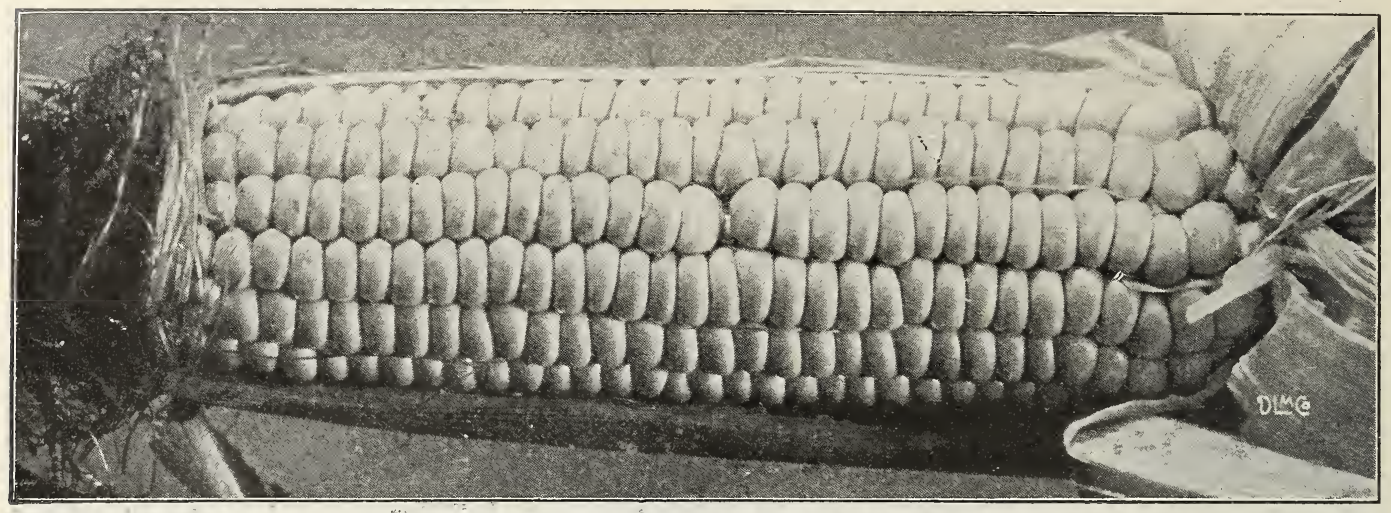

Hart's Improved Extra Early Dawn Corn $\vec{i}$

\section{SWEET CORN}

Much of the Sweet Corn Seed that is offered is produced in the West, where it can be grown much cheaper than it can in the East. But the West, with its level country, high winds, and vast areas of Field Corn, which mixes with the Sweet Corn, destroys that luscious sweetness so much prized in our Connecticut-grown seed. Our Sweet Corn seed is all grown here at home, where we make a specialty of growing the choicest strains. Our seed has the reputation of producing the nicest and sweetest Corn to be found. Our friends will be sure of getting something nice if they buy their Sweet Corn from us. Sweet Corn can be raised on any good, ordinary soil, but it should be deeply and thoroughly worked before planting, and cultivated frequently.

8 to Io ats. required for an acre, if planted in hills.

1 qt. weighs about 2 lbs.

Hart's Improyed Extra Early Dawn. Our improved strain of this splendid early Sweet Corn, is of better quality, and earlier than any other variety grown, and is the best money maker of them all. It is ready for market so early it always commands fancy prices, and a large piece can be cleaned up at high prices before any other variety is ready. It is deliciously sweet and fine flavored, and for so early a variety produces 'a large crop. Pkt. IOc., $1 / 2 \mathrm{lb}$. I 5c., I $1 \mathrm{~b}$. and over $25 \mathrm{c} .1 \mathrm{~b}$.

Golden Cream. A new yellow sort, having the same delicious qualities that make Golden Bantam so popular, and follows it in earliness; ears are rather larger, and the kernels have a tendency to be irregular instead of being in rows. Pkt. IOc., 1/2 lb. I5c., I $1 \mathrm{~b}$. and over $25 \mathrm{c}$. $1 \mathrm{~b}$.
Dreer's Aristocrat. A most desirable Sweet Corn, somewhat resembles Red Cory, which it follows closely in earliness, but the ears are larger, and the Corn is of delicious flavor, and very productive. Pkt. IOc., $1 / 2$ lb. I5c., I lb. and over $25 \mathrm{c}$. $1 \mathrm{~b}$.

Mammoth White Cory. One of the best of the extra early white varieties for either the market, or the home garden. The ears are quite large, being 7 inches long, and stalks grow about 4 feet high, each generally bearing two good ears, of fine shape, and delicious flavor. Pkt. IOc., $1 / 2$ lb. I5c., I lb. and over $25 \mathrm{c}$. $1 \mathrm{~b}$.

Pocahontas. This is a splendid extra early variety. The ears are larger and thicker than White Cory, and are always well filled out, and very sweet and delicious. Pkt. IOc., $1 / 2$ lb. I5c., I $1 \mathrm{~b}$. and over $25 \mathrm{c} .1 \mathrm{~b}$.

Howling Mob. A large eared, second early sort, very productive, white, and of excellent quality. Pkt. IOc., $1 / 2$ lb. I5 c., I lb. and over, $25 \mathrm{c}$. $1 \mathrm{~b}$.

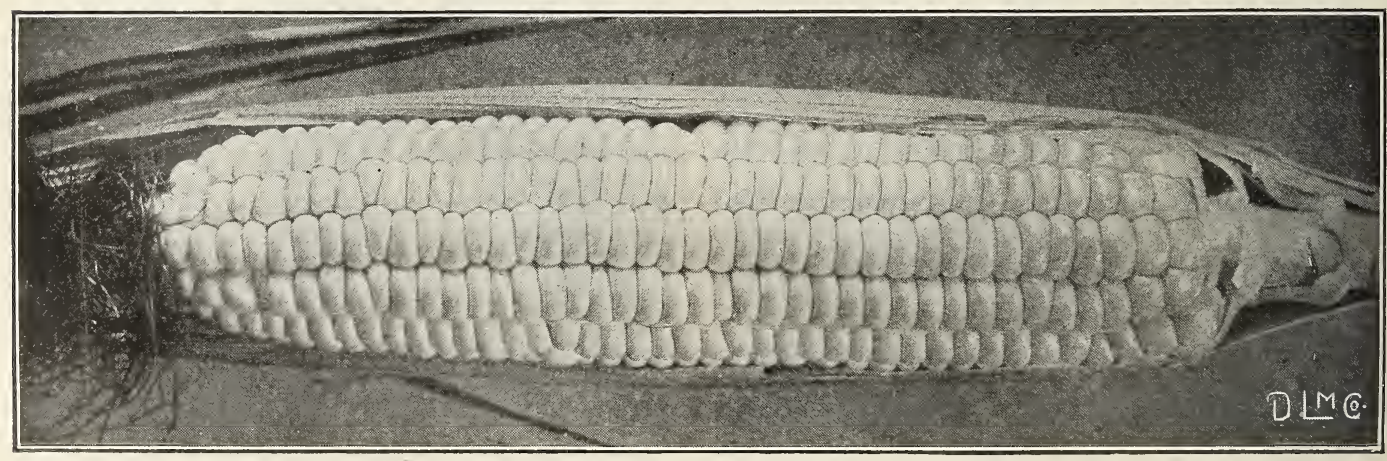

Golden Bantam Corn 


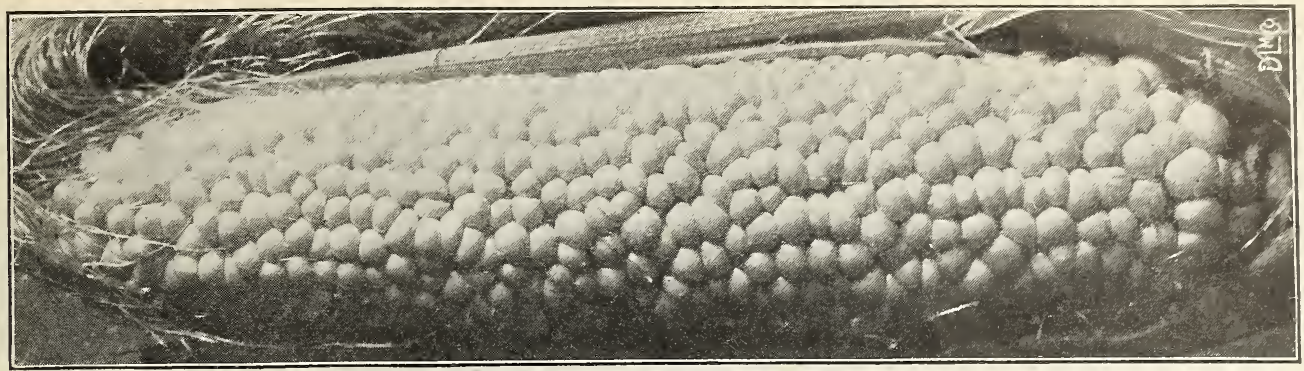

CORN-Continued

De Lue's Golden Giant. This delicious new variety should have a place in every garden. It is claimed by Dr. De Lue who first introduced it to be the earliest, sweetest, and most delicious Corn grown. We tried it out in our trial grounds, and although it did not prove to be as early as our Improved Extra Early Dawn, for yield and delicious sweetness, it is all the originator claimed for it. The stalks are dwarf, but produce a heavy crop; the ears are quite large, filled with deep creamy yellow kernels, and when served on the table, are very attractive, sweet and juicy, and of most delicious flavor. We offer the very limited quantity we grew from the sample we tried out. Every kernel is well cured, and of strong germination. Pkt. 25c.

Peep O' Day. Very early, tender and sweet. Pkt. I Oc., $1 / 2 \mathrm{lb}$. I $5 \mathrm{c}$., I lb. and over, $25 \mathrm{c} .1 \mathrm{~b}$.

Early Red Cory. Very early; good cropper; delicious flavor. Pkt. I oc., $1 / 2 \mathrm{lb}$. I $5 \mathrm{c}$., I lb. and over, $25 \mathrm{c} .1 \mathrm{~b}$.

Early Maine. Extra early; fine quality. Pkt. IOc., $1 / 2$ lb. I $5 \mathrm{c}$., I lb. and over, $25 \mathrm{c}, 1 \mathrm{~b}$.

White Cory. Very similar to Red Cory, except it has white cob and kernel. Pkt. IOc., $1 / 2$ lb. I5c., I lb. and over $25 \mathrm{c} .1 \mathrm{~b}$.

Golden Bantam. Golden yellow in color. This is a general favorite wherever used; is early, very tender, and the sweetest and most delicious Corn grown. Pkt. IOc., $1 / 2$ lb. I $5 \mathrm{c}$., I lb. and over $25 \mathrm{c}$. $1 \mathrm{~b}$.

Golden Rod. Very similar to Golden Bantam. andfollowing that popular variety in earliness, but is a much larger ear. Golden yellow in color. Pkt. I Oc., 1/2 lb. I5c., I lb. and over $25 \mathrm{c}$. $1 \mathrm{~b}$.

Early Minnesota. A standard early variety. Pkt. IOc., 1/2 1b. I5c., I lb. and over, $25 \mathrm{c}$. lb.

Early Crosby. One of the best sorts for all purposes. Pkt. I Oc., 1/2 lb. I 5c.,I l lb.andover, 25 c.lb.

Metropolitan. Second early; large ears. Pkt. IOc., $1 / 2 \mathrm{lb}$. I $5 \mathrm{c}$., I $1 \mathrm{~b}$. and over, $25 \mathrm{c}$. $1 \mathrm{~b}$.

Kendal's Early Giant. Medium early, large; good quality. Pkt. IOc., $1 / 2 \mathrm{lb}$. I5c., I lb. and over, $25 \mathrm{c} . \mathrm{lb}$

Early Large Champion. Produces the earliest large ears, and is the favorite market gardener's variety. Pkt. I0c., $1 / 2$ lb. I5c., I $1 \mathrm{~b}$. and over, $25 \mathrm{c}$. $1 \mathrm{~b}$

Perry's Hybrid. Medium early, and good size. Pkt. IOc., $1 / 2$ lb. I5c., I lb. and over, $25 \mathrm{c}$. $1 \mathrm{~b}$.

Black Mexican. Medium early; very sweet. While in its green state the kernels are white, but turn black as they ripen. Pkt. IOc., $1 / 2$ lb. 2oc., I lb. and over, $30 \mathrm{c}$. 1b.

Squantum, or Potter's Excelsior. Very sweet; a large, second-early variety. Pkt. Ioc., $1 / 21 \mathrm{~b}$. I $5 \mathrm{C}$., I lb. and over $25 \mathrm{c}$. $1 \mathrm{~b}$.

Moore's Early Concord. Thick, large ears and medium early. Pkt. IOc., $1 / 2 \mathrm{lb}$. I5c., I $1 \mathrm{~b}$. and over, 25c. $1 \mathrm{~b}$.

Early Evergreen. Very similar to Stowell's Evergreen, but is a week to ten days earlier. Pkt. IOc., 1/2 lb. I $5 \mathrm{c}$., I lb. and over, 25c. lb.

White Evergreen. This is a high-bred, white type of Stowell's Evergreen; very sweet and delicious, and, on account of its paper whiteness, is very attractive when served on the table. Ears large, with very deep kernels. Pkt. IOc., $1 / 2 \mathrm{lb}$. I5c., I lb. and over, $25 \mathrm{c} .1 \mathrm{~b}$.
Zig-Zag Evergreen. This fine strain possesses the sweet, delicious flavor of the Stowell's Evergreen, but is earlier and the grains run zig-zag, instead of in straight rows. Pkt. IOc., $1 / 2 \mathrm{lb}$. I5c., I $1 \mathrm{~b}$. and over $25 \mathrm{c}$. $1 \mathrm{~b}$.

Stowell's Evergreen. The standard variety for the home garden, market and canning. The kernels are long, tender and sweet. Pkt. I Oc., 1/2 lb. I5c., I lb. and over $25 \mathrm{c}$. $1 \mathrm{~b}$.

Country Gentleman. The best late sort of all for the home table. Cob is small, and crowded with long, irregular kernels, tender and sweet. Pkt. Ioc., $1 / 2$ lb. I 5 c., I lb. and over $25 \mathrm{c} .1 \mathrm{~b}$.

Long Island Beauty. Most desirable late sort; quality extra good. Pkt. Ioc., 1/2 lb. I5c., I lb. and over $25 \mathrm{c} .1 \mathrm{~b}$.

Late Mammoth. Very tall, late sort, with mammoth ears of the best quality; sweet and tender. Pkt. IOc., 1/2 lb. I5c., I lb. and over $25 \mathrm{c}$. $1 \mathrm{~b}$.

Narrow Grained Evergreen. A splendid high quality Evergreen. Large ears, slim cob, containing I8 to 20 rows very deep narrow grains. One of the best canning sorts. Pkt. IOc., 1/2 lb. I5c., I lb. and over $25 \mathrm{c} .1 \mathrm{~b}$.

New England Sugar. A very desirable early variety. Ears about 6 to 8 inches long, kernels broad, very sweet and tender. Pkt. Ioc., $1 / 2$ lb. I5c., I lb. and over $25 \mathrm{c} .1 \mathrm{~b}$.

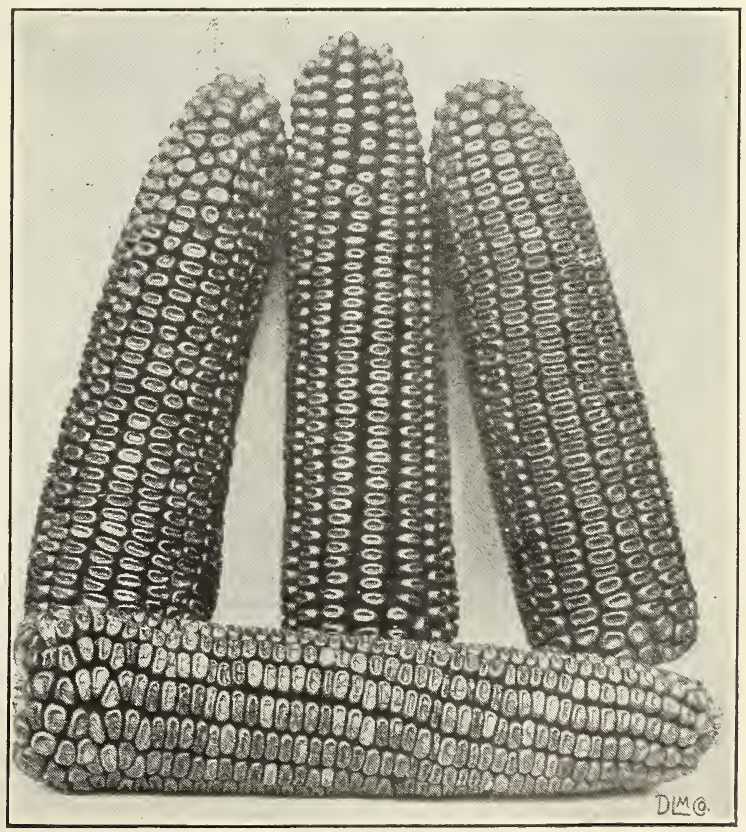

Improved Leaming Corn 


\section{Field and Ensilage Corn}

If a bag or more is wanted, write us for special prices

Extra Early Adams. The earliest Corn of all, and first to make ears; stalks dwarf and stocky; kernels white. I lb. and over Ioc. $1 \mathrm{~b}$.

Early Large Adams. Although not a Sweet Corn, can often be used as such on account of its fine white kernels, which are quite sweet and tender. Is very hardy, and can be planted earlier than Sweet Corn. I $1 \mathrm{~b}$. and over Ioc. $1 \mathrm{~b}$.

Improved Leaming. A great yielder; the kernels are long and a deep golden yellow. The best Yellow Dent Corn on the market. 8c. lb., 56 lbs., and over $7 \mathrm{c} .1 \mathrm{~b}$.

Eureka Ensilage. A large, leafy sort. One of the best for silos. 9c. 1b., 56 lbs. and over $8 \mathrm{c}$. $1 \mathrm{~b}$.

90 Day Yellow Field. An early yellow Flint Corn, matures in about 90 days. Ears, and stalks, smaller than yellow Canada. Lb. 9c., 56 lbs. and over 7c. lb.

Yellow Canada Field. The standard yellow Flint variety, grows a good sized stalk, good sized ears, 8 rows, and kernels solid and compact. Matures in from IIO to I 20 days. Lb. 9c., 56 lbs. and over 7c. $1 \mathrm{~b}$.

Longfellow Flint. A popular and profitable variety, very long, slim ears, a big yielder, makes a good growth of stalks, matures in IIO to I 20 days. Lb. 9c., $56 \mathrm{lbs}$. and over 7c. lb.

Early Mastodon. One of the best ensilage sorts, very large and leafy, resembles Leaming, but is earlier. Lb. $8 \mathrm{c} ., 56 \cdot 1 \mathrm{bs}$, and over $7 \mathrm{c}$. $1 \mathrm{~b}$.

Golden Orange Flint Seed Corn. This Corn will mature under good conditions in from 80 to 90 days. It grows a good leafy stalk but is not recommended for ensilage as the stalks do not attain a height ordinarily over 7 to 9 feet. It matures on thin hilly lands and poor soils, where other Corns will make only nubbins. Lb. 9c., $56 \mathrm{lbs}$. and over $8 \mathrm{c}$. $1 \mathrm{~b}$.

Giant White Cap Ensilage, or Husking Seed Corn. This Corn requires about IIo days for maturity in an ordinary season. The stalks attain a height of about I2 feet in good land and proper tillage. Yields depend upon care, fertility of soil and the season. Ordinarily about Ioo to I 50 bushels ears per acre. This is one of the best corns for ensilage as the ears develop quickly and the stalks are leafy and heavy. This Corn requires a richer soil than the Flint and therefore is not recommended for poor, hilly lands. Lb. 9c., 56 lbs. and over 8c. Ib.

Pop Corn, White Rice. The most popular variety. Pkt. 5c., 1/2 1b. I5c., 1b. and over $25 \mathrm{c}$. 1b.

\section{CRESS, or PEPPERGRASS}

A popular salad which should be sown early in the Spring in drills, at short intervals for succession, as it soon runs to seed.

Extra Curled. The best variety; used for garnishing. Pkt. 5c., oz. IOc., $1 / 4$ lb. 20 c., 1b. $50 \mathrm{c}$.

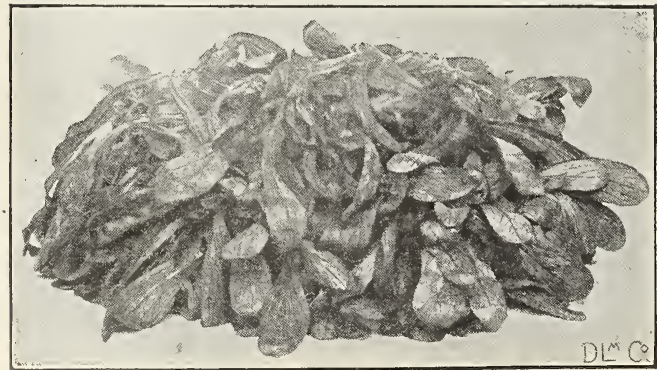

Corn Salad

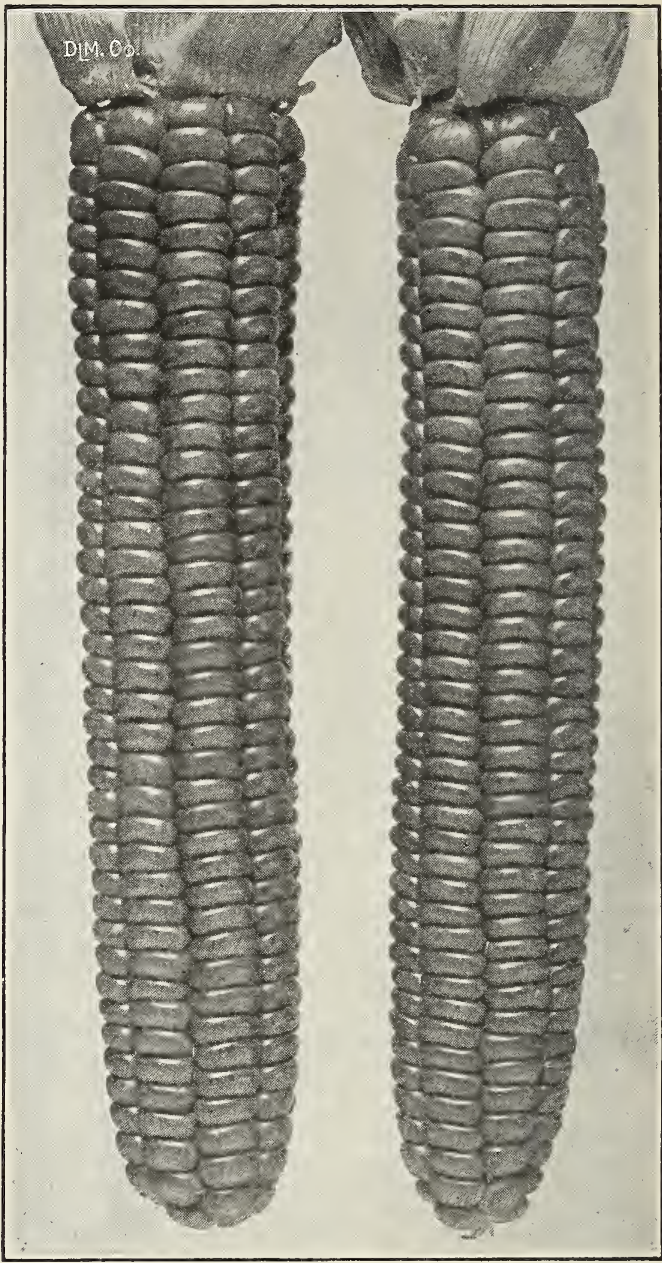

Longfellow, Yellow Flint]

\section{CORN SALAD}

Culture.-This excellent salad may be had the year round. For Summer use, plant in early Spring. For Winter and early Spring use, sow in August and September, and protect with a covering of straw on approach of Winter. Sow thickly in shallow drills I 2 to I 4 inches apart, and press the soil down firmly on the seed.

One ounce will sow Ioo feet of drill.

Large Seeded. The most popular vairety. Pkt. 5c., oz. I 5 c., $1 / 4 \mathrm{lb}$. $50 \mathrm{c}$.

\section{DANDELION}

Culture.-This is one of the earliest, as well as the best and most healthful Spring greens, or salads. Sow from May to last of June, in drills I4 inches apart, and thin out to 5 or 6 inches in the row. Cultivate frequently, and the following Spring they will be fit for use.

One ounce will sow I 50 feet of drill.

Improved Broad Leaf. An improved thick-leaved variety. Crop failed.

French Cultivated. Popular for greens. Pkt. Ioc., cz. $50 c$. 


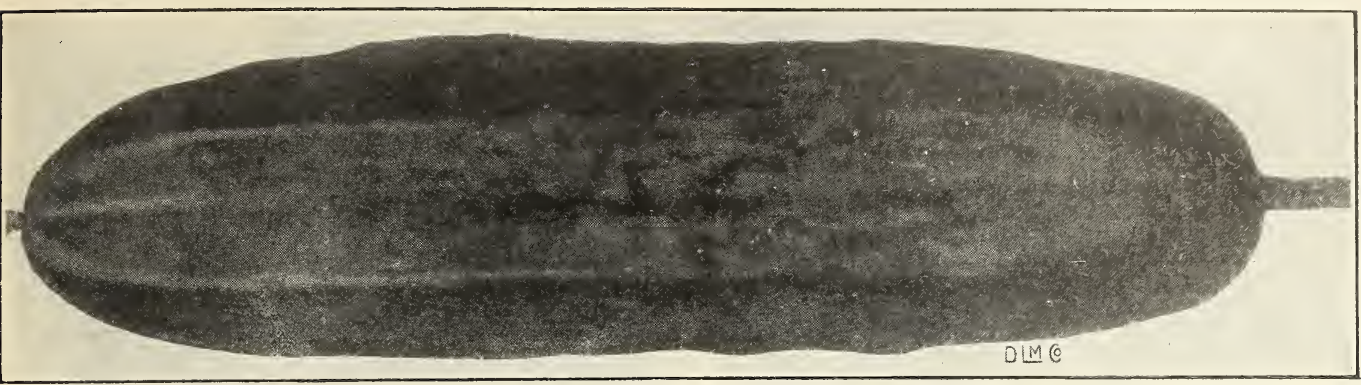

Early Arlington White Spine Cucumber

\section{CUCUMBER}

Culture.-Cucumbers succeed best in a rich, loamy soil. To get early vines, start in hotbed, about middle of April. Seed can be sown in pieces of sod, grass side down, and when weather will permit can be placed in the prepared hills, 4 feet apart each way. For a general crop, plant in the open ground in May. When danger of bugs is past, thin out to 4 vines in a hill. For pickles, plant middle of June to middle of July. Sprinkle vines with plaster, or spray them to protect from bugs.

\section{About 3 lbs. of seed required for an acre.}

Henderson's Perfected. A very dark colored type of White Spine; fruits about 8 inches long, thick and square ending. Pkt. $5 \mathrm{c} .$, oz. I2c., $1 / 4 \mathrm{lb}$. $35 \mathrm{c} ., 1 \mathrm{~b}$. $\$ 1.25$.

Early Fortune. One of the best types of White Spine. Early and very productive, fruits 9 inches long, slightly tapering, color dark green, and does not fade when shipped a long distance. Pkt. 5 c., oz. I $2 \mathrm{c}$., $1 / 4$ lb. 35c., 1b. \$I.25.

Hill's Forcing. A type of White Spine, and one of the best for forcing. Pkt. 5c., oz. I 2c., $1 / 4 \mathrm{lb} .35 \mathrm{c}$, 1b. \$1.25.

Early Russian. A small extra early variety. Pkt. 5c., Oz. I 2c., $1 / 4$ lb. 35c., lb. \$I.25.

Early Cluster. Medium size; vines bear in clusters. Pkt. 5c., Oz. I 2 c., $1 / 4$ lb. 35c., lb. \$I.25.

Boston Pickling. A favorite pickling sort. Pkt. 5c., Oz. I 2c., $1 / 4$ lb. 35 c., lb. \$I.25.

Davis' Perfect. The best and most profitable Cucumber for the market gardener, or the home garden. They are early, very long, dark green. Can be produced out of doors, and sell in the market for hothouse grown, and always bring a good price. Pkt. $5 \mathrm{c} ., \mathrm{oz}$. I5c., $1 / 4$ lb. 40 c., lb. $\$ 1.50$.

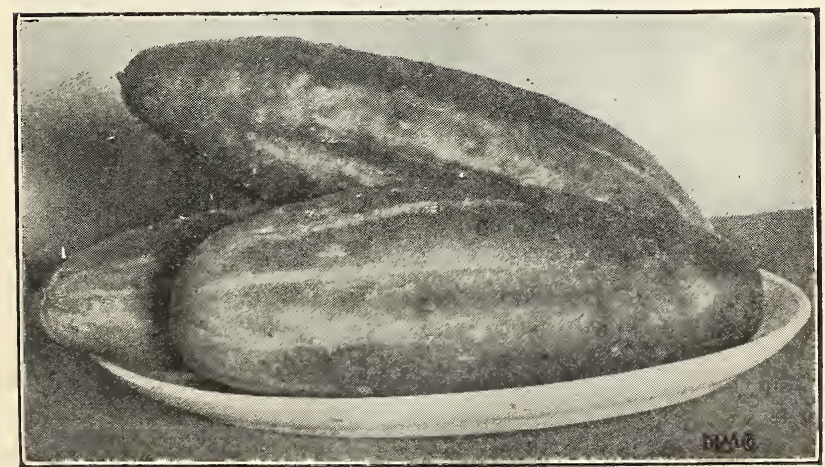

Cool and Crisp Cucumber
Early Arlington White Spine. One of the best sorts for forcing; the fruit is long, dark green, uniform in size, and crisp, tender flesh of excellent flavor. Pkt. 5c., Oz. I 2c., $1 / 4$ lb. 35c., lb. \$1.25.

New Century White Spine. A new fine strain, 8 to Io inches in length, rich dark green, smooth and regular. The skin is quite thin and tender, flesh white and crisp. The seed space is firm and solid, making an excellent slicing variety. Pkt. $5 \mathrm{c} ., \mathrm{oz}$ I 2 c., $1 / 4$ lb. 35 c., lb. $\$$ I.25.

Fordhook Famous White Spine. One of the largest and most attractive Cucumbers grown. It retains its deep green color longer than any other variety. The flesh is very thick and mild flavor. Vines are of strong, vigorous growth and bear continuously throughout the season. Pkt. $5 \mathrm{c}$., oz. I2c., 1/4 lb. $35 \mathrm{c}$., 1b. $\$$ I.25.

Improved White Spine. Excellent for slicing or pickles. Pkt. 5c., Oz. I 2c., $1 / 4$ lb. 35 c., 1b. $\$ \mathrm{I} .25$.

Green Prolific. Uniform size; fine for pickles. Pkt. 5c., OZ. I 2c., $1 / 4$ lb. 35c., lb. \$I.25.

Klondike. An extra early, fine strain of White Spine. Pkt. 5c., oz. I 2c., 1/4 lb. 35c., lb. \$I.25.

Improved Long Green. Extra long; fine for slicing or pickles. Pkt. 5c., oz. I5c., $1 / 4$ lb. $40 \mathrm{co}$, lb. \$I.5O.

Everbearing. Early and productive. Pkt. 5c., oz. I 2 c., $1 / 4$ lb. 35c., lb. $\$$ I.25.

Cool and Crisp. Medium length; tender and crisp. Pkt. 5c., oz. I2c., $1 / 4$ lb. 35 c., lb. $\$ \mathrm{I} .25$.

Jersey Pickling. An excellent sort for both table use and pickling. Vines vigorous and productive. Fruit straight, handsome, small at each end, crisp and tender, and make excellent pickles. Pkt. 5c., OZ. I2c., $1 / 4$ lb. 35c., 1b. \$I.25.

Japanese Climbing. The strong vines throw out numerous tendrils and can be trained upon a trellis, or chicken wire, which ensures earlier ripening and better fruits. It endures Summer heat and drought exceedingly well. The Cucumbers are very long, dark green and flesh is crisp and mild flavored. Pkt. 5c., Oz. I2c., $1 / 4$ lb. 35c., lb. \$I.25. 


\section{CHICORY}

Culture.-Sow the seed in May, transplant or thin out to 6 inches apart, and keep the soil well cultivated. The plants form roots which by Oct. Ist, will have a thickness of 2 to 3 inches, and stalks of leaves that grow like Cos or Romaine Lettuce. About the middle of October, by which time they should be fully grown, tie the cleaves closely together, and blanch like Celery, either by placing boards against them, or by banking up with soil. Two or three weeks are sufficient to whiten the hearts for use. They may be taken up roots and all, and stored in a cool cellar, or trenched like Celery; in this way the hearts will whiten and they can be kept all Winter to be used as wanted.

One ounce will sow roo feet of row.

Witloof (French Endive). This is the choicest of all the Winter salads, and is delicious when served with French dressing, and eaten like Cos Lettuce. It grows in a solid oblong head, and blanches ivory white. When lifting, cut whole head with part of the roots to hold the leaves together. Pkt. 5c., oz. $20 \mathrm{c} ., 1 / 4 \mathrm{lb}$. $75 \mathrm{c}$.

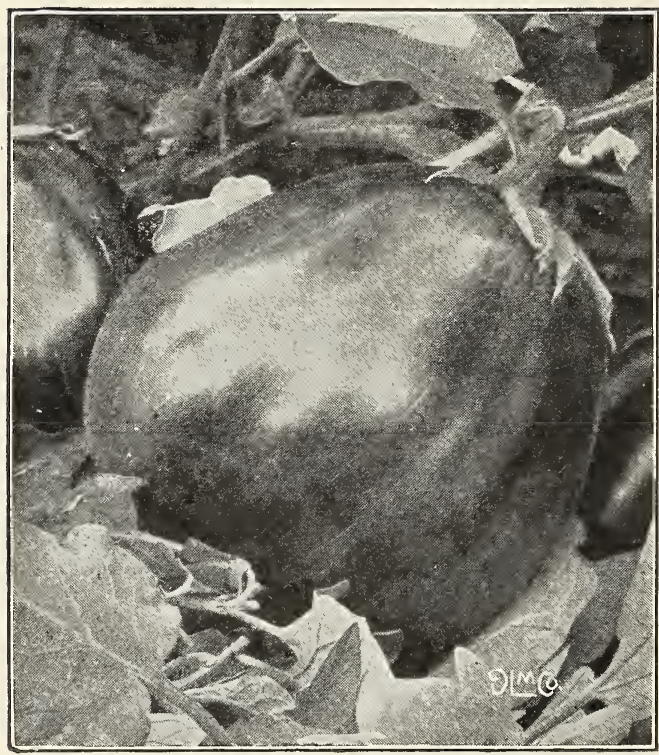

New York Improved Purple Egg Plant

\section{EGG PLANT}

Culture.-This seed germinates slowly and should be started in the hotbed in March or April. When 3 inches high transplant into coldframes, 4 inches apart, or set them into small pots and protect from the cold. After all danger from cold nights is past, gradually harden by exposure and transplant in the open ground, 2 feet apart. Shade, when first transplanted, and protect from the potato bug, which is one of the worst obstacles encountered in Egg Plant culture. Draw earth up to stem when about I foot high.

One ounce will produce about Iooo plants.

New York Improved Purple. One of the best for market and private use. Pkt. 5c., oz. 40c., $1 / 4 \mathrm{lb}$. $\$$ I.50, lb. \$6.0o.

Black Beauty. An early prolific variety; fruit round; skin black. Pkt. 5c., oz, 40c., 1/4 lb. \$1.50, 1b. \$6.00.

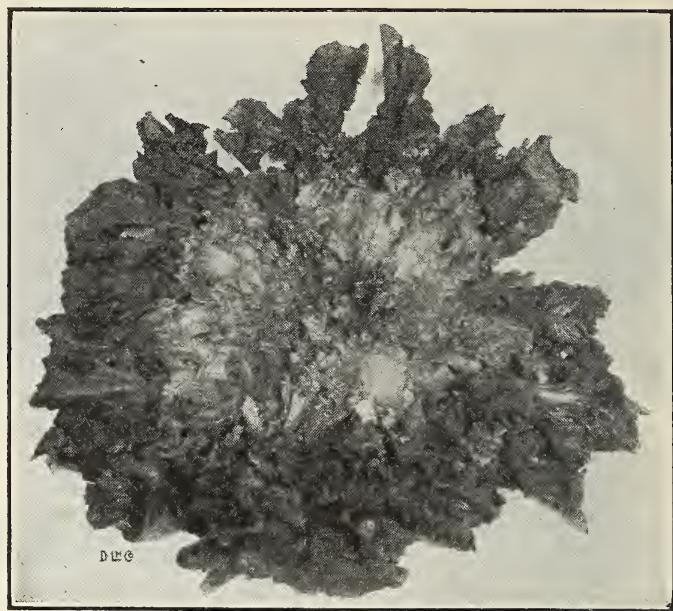

Broad-Leaf Batavian Endive

\section{ENDIVE}

Culture.-One of the best and most wholesome salads for Fall and Winter use. Sow in April for early use, and in June and July for Fall and Winter use. When leaves are about 8 inches long, tie them together with a string near the top to blanch.

One ounce will sow I50 feet of drill.

Moss Curled. Grows more compact than the other sorts, and the leaves are finer curled, and blanches a creamy white. Pkt. 5c., Oz. Ioc., $1 / 4$ lb. 25c., lb. 9oc.

Green Curled. Finely curled leaves, tender and crisp. Pkt. 5c., Oz. IOc., $1 / 4$ lb. $25 \mathrm{c}$., lb. $90 \mathrm{c}$.

White Curled." Very tender and easy to blanch. Pkt. 5c., oz. IOc., $1 / 4$ lb. $25 \mathrm{c}$., lb. 9oc.

Broad-Leaf Batavian (Escarolle). Leaves are wide, thick and straight; very tender and crisp: Pkt. 5c. oz. IOc., $1 / 4$ lb. $25 \mathrm{c}$., lb. $90 \mathrm{c}$.

\section{OUR CREED}

We believe in small farms and gardens, well manured, and thoroughly cultivated.

We believe in big crops, leaving the land better, and the farmer richer.

We believe every farmer should own a good farm, have a good wife, provide her with conveniences and pleasant surroundings, have good buiidings, good fences, good stock, a good orchard-and children enough to gather the fruit.

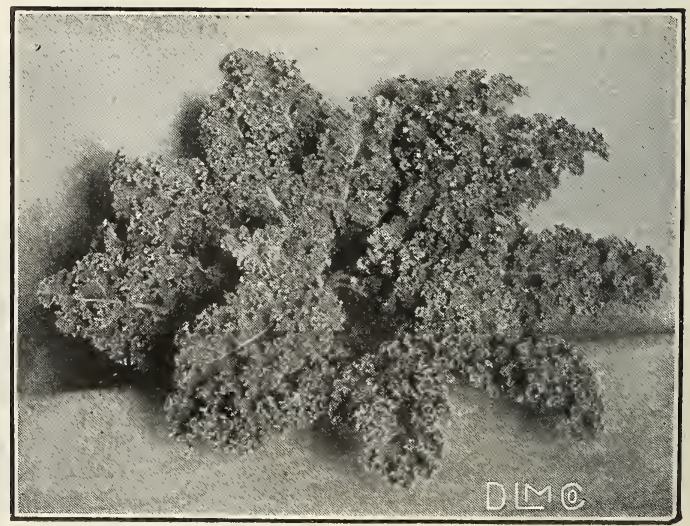

Dwarf Siberian Kale 


\section{GOURDS}

Culture same as Squashes. The vines make a rapid growth and are much used for covering old fences, trellises, stumps, etc. The foliage is ornamental, with curiously shaped fruit of extraordinary markings. They are a tender annual and grow Io to 20 feet high.

Mixed Varieties. Pkt. 5c., oz. IOc., 1/4 1b. 25c., lb. $\$$ I.oo.

\section{KALE, or BORECOLE}

\section{(German Greens)}

A species of Cabbage forming a mass of leaves, some varieties being very beautiful and curled. The leaves are cooked as greens. Sow in April for early use, and in August and September for Winter and early Spring use. Sow in drills, I 4 inches apart, and thin to 4 inches in the row. Protect with a light covering of straw or litter during the Winter.

One ounce will sow I5o feet of drill

Green Curled Scotch. Most popular sort for general use. Pkt. 5c., oz. I5c., 1/4 lb. 60c., 1b. \$2.00.

Dwarf Siberian. The best for Fall sowing. Pkt. $5 \mathrm{c}$, Oz. I5c., $1 / 4$ lb. 6oc., lb. $\$ 2.00$.

Conomicut, R. I.; Oct. 28, 1919. "I have taken six ribbons at Grange Fairs on Vegetables grown from your seeds."

H. O. K.

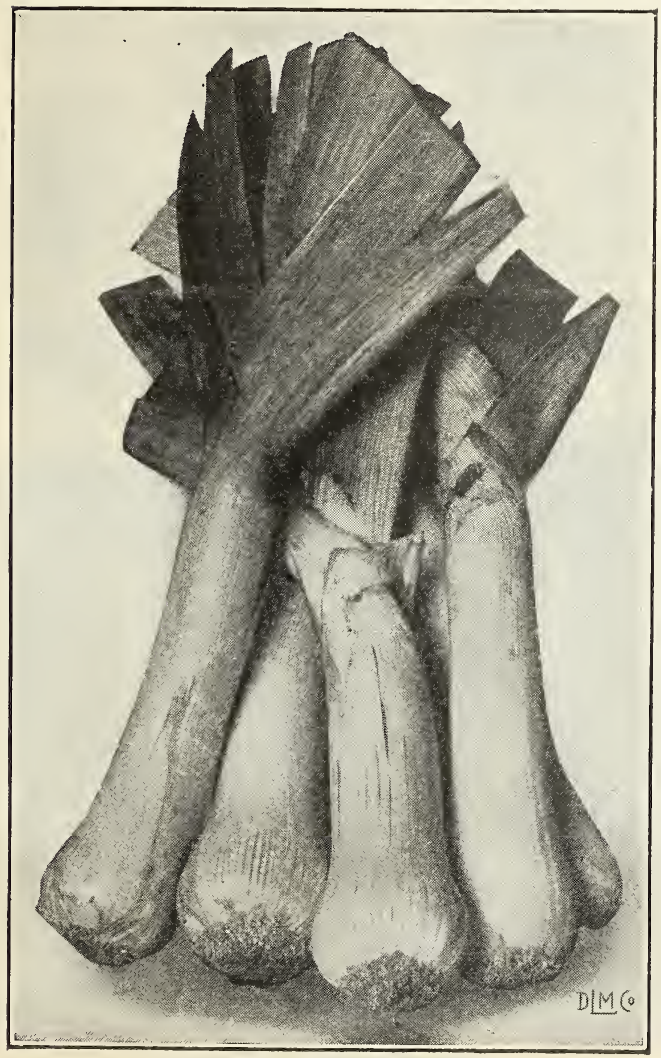

American Flag Leek

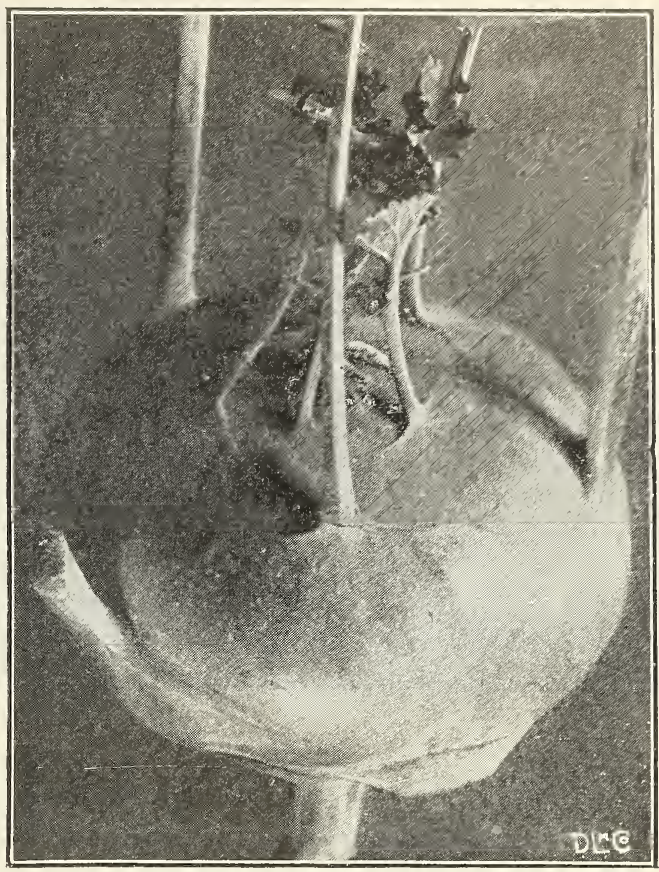

Early White Vienna Koh1 Rabi

\section{KOHL RABI}

A plant forming a bulb above the ground and bearing short leaves. The bulb is the edible part, and when cooked combines the virtues of the Turnip and Cabbage, but excels both in nutritive, hardy and productive qualities.

Culture.-Sow in early Spring for Summer use, and in July for Fall use. Plants should be thinned out to 8 inches in the row.

One ounce will sow I 50 feet of drill.

Early White Vienna. The most desirable for general use. Pkt. 5c., oz. I 5c., $1 / 4$ lb. 50c., lb. $\$ 2.00$.

Early Purple. An early variety with purple bulb. Pkt. 5c., Oz, I5c., $1 / 4$ lb. 50c., 1b. $\$ 2.00$.

\section{LEEK}

A species of Onion which does not form a bulb, but is used for its mild and delicious root, stem and neck.

Culture.-Sow early in Spring, in drills I4 inches apart and thin out to about 4 inches. When well grown, hill up with earth to get a long, white stem.

One ounce will sow Ioo feet of drill.

American Flag. Most popular variety; forms large stems of good flavor. Pkt. 5c., oz. 20c., 1/4 lb. 70c., 1b. $\$ 2.75$.

Giant Musselburgh. The largest variety; mild and good flavor. Pkt. 5c., Oz. 20c., 1/4 lb. 70c., lb. $\$ 2.75$.

South Coventry, Conn., July 23, 1919.

"All of your seed came up fine. I must tell you of the fun I had last year with those Mammoth Pumpkins I grew from your seed. I placed a huge one in the window of one of our Willimantic stores and cut it into a number of parts and had considerable "chewing" to do, to convince parts and had considerable the ing to do, to convince gave it around to different ones and they all liked it for pies." Yours very truly,

H, E, H 


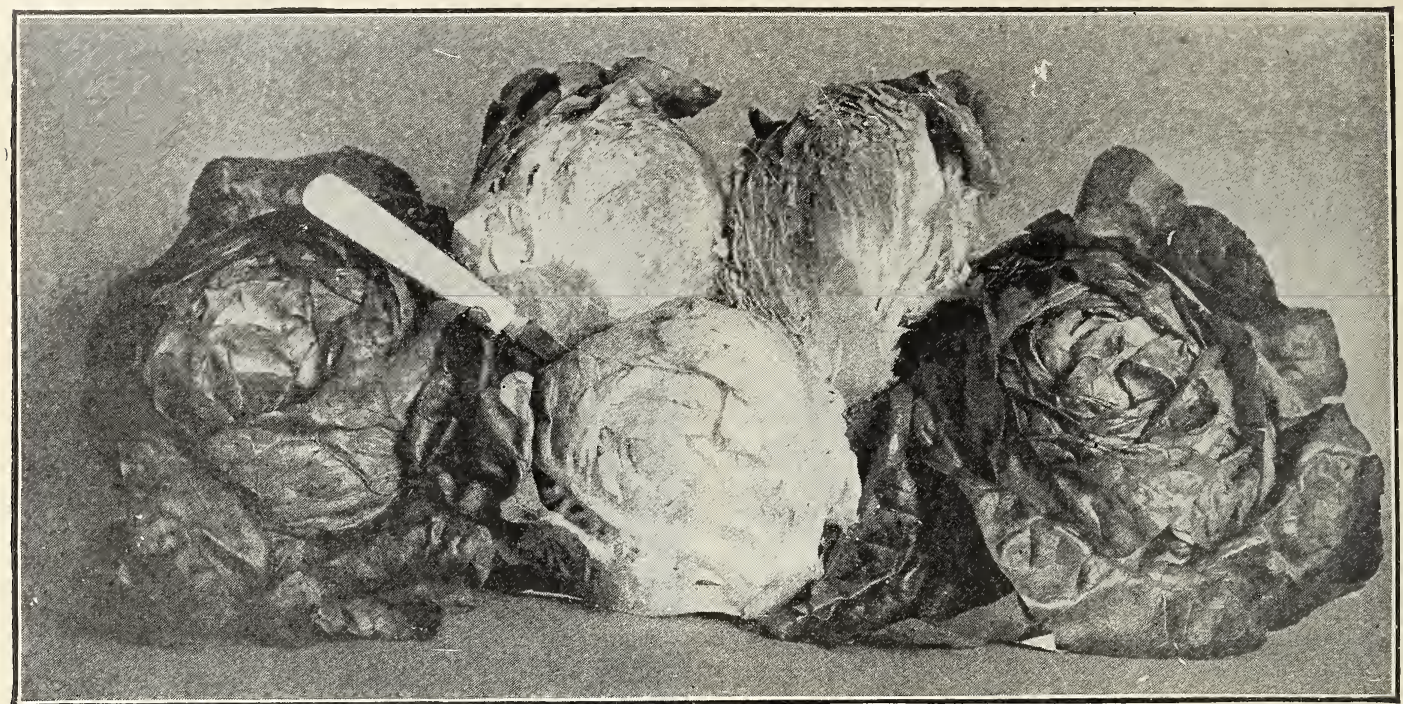

Big Boston Lettuce

\section{LETTUCE}

Culture.-No vegetable is more universally used than Lettuce, and to be thoroughly appreciated it must be brought to the table fresh and unwilted; quality depends largely upon rapid and vigorous growth. Have the soil well enriched, and keep it moist. Give it plenty of water, and you will have delicious, tender Lettuce. Sow in hotbed in March, and transplant, for very early plants. For general use, sow in the open ground, as early as ground can be worked, in drills I4 inches apart; thin out as they grow. To get good heads, plants should be Io inches apart in the row. For a succession sow every two or three weeks during the season.

One ounce will sow I 50 feet of drill.

Boston Curled. A curled heading sort, crisp, small and medium early. Pkt. 5c., oz. I 2c., 1/4 Ib. 35c., lb. $\$ 1.25$.

Detroit Forcing. Excellent for growing under glass, it stands a high temperature, and can be crowded to maturity, it is also well adapted for outdoor growing. Pkt. 5c., oz. I 2c., $1 / 4$ lb. 35c., lb. \$I.25.

Unrivaled. Similar to Big Boston in form and habit of growth, but it is a lighter shade of green, and without the brownish tinge at the borders. Pkt. 5c., Oz. I 2c., 1/4 lb. 35c., lb. \$I.25.
Denver Market. A crisp, oval heading sort; leaves short, crumpled, and frilled on the edges, color light green. Pkt. 5c., oz. I $2 \mathrm{c} ., 1 / 4 \mathrm{lb}$. $35 \mathrm{c}$., lb. $\$ \mathrm{I} .25$.

Hanson Improved. A reliable sure heading sort, heads large and late; leaves large and broad, crumpled and frilled at the edges. A fine variety for midsummer planting outside, as it stands the hot season better than most sorts. Pkt. 5c., oz. I2c., $1 / 4 \mathrm{lb}$. $35 \mathrm{c} ., 1 \mathrm{~b} . \$ \mathrm{I} .25$.

Mammoth Butter Head. Heads very large, and fairly firm; leaves are light green and much crumpled. Pkt. 5c., oz. I 2c., 1/4 lb. 35c., lb. \$I.25.

Simpson's Early Curled. One of the earliesi and best loose curled heads. Pkt. 5c., Oz. I 2c., $1 / 4$ lb. 35c., lb. \$I.25.

Simpson's Black Seed. Loose, curled, light green leaves. Pkt. 5c., Oz. I2c., $1 / 4$ lb. 35c., lb. \$I.25.

Grand Rapids. A good forcing variety; very curly and attractive. Pkt. $5 \mathrm{c}$. oz. I 2 c., $1 / 4$ lb. 35 c., lb. $\$$ I. 25

Prize Head. Very tender, reddish-brown leaves, curled and attractive. Pkt. $5 \mathrm{c}$., oz. I 2c., $1 / 4$ lb. 35 c., lb. $\$$ I.25.

May King. A very choice early head Lettuce. One of the best for coldframe, or outdoor culture. Heads are good size, early, solid and tender. Wherever grown it is sure to become very popular. Pkt. 5c., Oz. I 2c., 1/4 lb. 35c., 1b. \$I.25.

Big Boston Head. A popular market variety; forms large solid heads. Pkt. 5c., Oz. I 2c., $1 / 4$ lb. 35c., lb. \$I.25.

Boston Market. Popular forcing sort heads crisp and solid. Pkt. 5c., oz. I2c., $1 / 4$ lb. 35 c., lb. \$I.25.

Tennis Ball, Black Seed. Desirable for forcing in Winter, and withstands the Summer heat well. Forms solid, crisp heads. Pkt. 5c., Oz. I2C., $1 / 4 \mathrm{lb}$. 35 c., lb. $\$$ I.25. 


\section{LETTUCE-Continued}

Wonderful, or New York Head. A large, crisp tight-heading variety; leaves are dark green and curled at the edges. Pkt. 5c., Oz. I5c., $1 / 4$ lb. $40 \mathrm{c}$., lb. \$I.50.

Hartford Bronze Head. Forms large compact heads of a beautiful bronzed red color shading to dark green toward the roots. A distinct variety and has no equal. Pkt. 5 c., oz. I2c., $1 / 4$ lb. 35 c., lb. \$I.25.

Iceberg. Heads compact and solid, with curled, light green leaves, tinged with red at the edges. Pkt. 5c., oz. I2c., $1 / 4 \mathrm{lb}$. 35c., lb. \$I.25.

Deacon Head. Forms large, buttery heads, very tender and crisp. Pkt. 5c., oz. I2c., $1 / 4$ lb. 35c., lb. $\$$ I.25.

Brown Dutch. Forms large, solid heads, leaves smooth and bronzed with red Pkt. 5c., Oz. I2c., $1 / 4$ lb. 35c., lb. $\$$ I.25.

White Paris Cos, or Romaine. Best of the Cos varieties; leaves should be tied up for a few days to facilitate blanching. Pkt. 5 c., oz. I2c., $1 / 4$ lb. 35 c., lb. \$I.25.

Wayahead. A very early, sure heading variety. The inner head blanches a rich buttery yellow; of superior quality. Pkt. 5c., OZ, I 2 c., $1 / 4$ lb. 35c., lb. \$I.25.

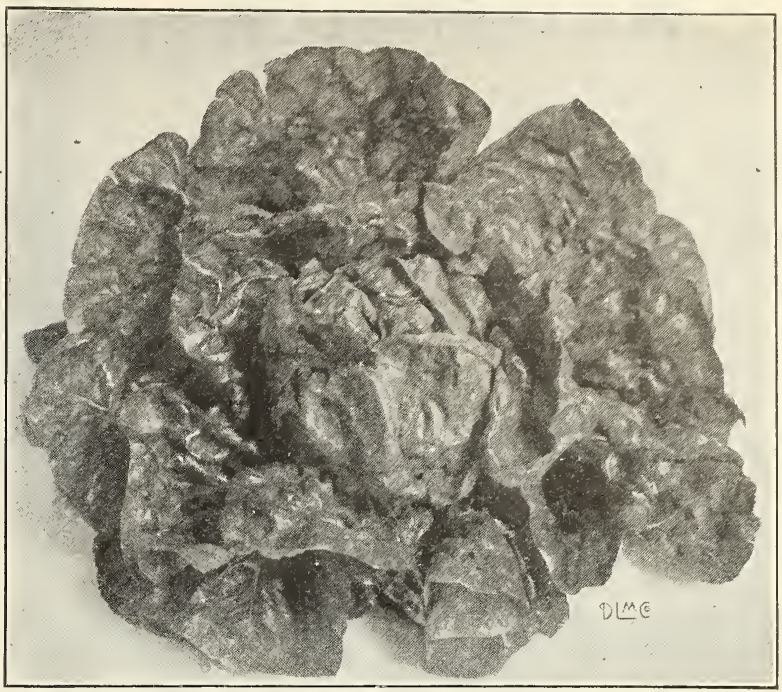

Wonderful, or New York Head Lettuce

\section{MUSKMELON}

Culture.-A warm, rich, sandy loam is best adapted for Melon culture. The middle of May is early enough for planting in the open ground, but the crop can be forced by starting in hotbed on sods and transplanting same as Cucumbers. Plant in hills 5 to 6 feet apart each way. When danger from bugs is over, thin to 3 or 4 plants in a hill. When the main shoot is a few feet long, pinch off the ends to force the laterals on which the fruit is borne.

One ounce for 80 hills; 3 lbs. for an acre.

Bayview. Very large, early and productive; fruit long and well netted, flesh green and fine quality. Pkt. 5c., Oz. IOc., 1/4 lb. 25 c., lb. $90 \mathrm{c}$.

Large Late Hackensack. Fruit large, round, flattened at the ends; deeply ribbed, and heavily netted; flesh green, thick and fine quality. Pkt. $5 \mathrm{c}$., oz. IOc., $1 / 4$ lb. 25c., lb. $90 \mathrm{c}$.

Grand Rapids Market. A large, extra early sort, oblong in shape, green, turning to yellow when ripe. The flesh is orange color almost to the rind, skin finely netted. Pkt. 5c., oz. Ioc., $1 / 4$ lb. $25 \mathrm{c}$., lb. 9oc.

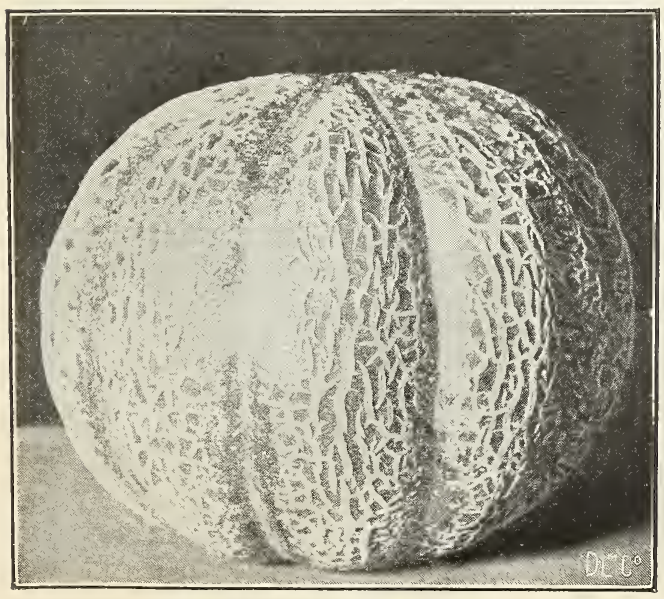

Emerald Gem Muskmelon
Green Citron. Early; medium sized; flesh deep green' fine flavor. Pkt. 5c., oz. Ioc., $1 / 4$ lb. $25 \mathrm{c}$., lb. $90 \mathrm{c}$.

Extra Early Hackensack. Excellent for market or private garden. Heavily ribbed and netted; flesh thick and light green. Pkt. 5c., oz. Ioc., 1/4 1b. $25 \mathrm{c}$., lb. $90 \mathrm{c}$.

Emerald Gem. A salmon-pink variety of delicious flavor, skin generally smooth; deep emerald green color, and ripening to the rind; very sweet. $\mathrm{Pkt} .5 \mathrm{c}$., Oz. IOc., $1 / 4$ lb. 25 c., lb. $90 \mathrm{c}$.

Jenny Lind. Very early and prolific; small and netted; flesh green and sweet. Pkt. 5c., oz. Ioc., $1 / 4$ lb. 25 c., lb. $90 \mathrm{c}$.

Rocky Ford, or Netted Gem. One of the earliest and best Melons. Uniform in size and shape, being oval and finely netted; flesh deep green, luscious and sweet. Pkt. 5c., oz. 10c., 1/4 lb. 25c., 1b. $90 \mathrm{c}$.

Miller's Cream, or Osage. A large-sized, salmonfleshed variety. Pkt. 5c., oz. Ioc., $1 / 4$ lb. $25 \mathrm{c}$., $1 \mathrm{~b} .90 \mathrm{c}$.

Acme, or Baltimore. Flesh is thick, green and very sweet. Pkt. 5c., Oz. IOc., 1/4 lb. 25 c., lb. $90 \mathrm{c}$.

Long Island Beauty. An early, large, green-fleshed variety, of good quality. Pkt. 5c., oz. Ioc., $1 / 4 \mathrm{lb}$. $25 \mathrm{c} ., 1 \mathrm{~b} .9 \mathrm{oc}$.

Burrell's Gem. A medium-sized, oval variety, deep netted, having salmon or red flesh, has an entirely distinct and delicious flavor. Pkt. 5c., oz. Ioc., $1 / 4$ lb. 25 c., lb. $90 c$. 


\section{WATERMELON}

Culture.-Same as for Muskmelons, except they should be planted 8 feet apart.

One ounce will plant 25 hills; 4 lbs. to the acre.

Harris Early. Medium size, extra early, oblong, striped and mottled; flesh sweet and solid. Pkt. 5c., Oz. IOc., $1 / 4$ lb. $25 \mathrm{c}$., lb. $90 \mathrm{c}$.

Hungarian Honey. A superb early variety, globeshaped, color dark green mottled with darker shade; flesh brilliant red, ripening clear to the rind, and of delicious quality. Pkt. 5c., Oz. IOc., $1 / 4$ lb. $25 \mathrm{c}$., 1b. $90 \mathrm{c}$.

Striped Gypsy. Fruits large and long, striped and mottled; flesh deep scarlet, sweet and delicious. Pkt. 5c., oz. IOc., 1/4 lb. 25 c., 1b. 9oc.

Cuban Queen. A good keeper and fine shipper, very large, slightly oblong, flesh solid and very sweet. Pkt. 5c., oz. Ioc., $1 / 4$ lb. 25 c., 1b. 9oc.

Kentucky Wonder. A distinct red-seeded variety, oblong in shape, rind dark green with lighter stripes, flesh rich and sugary. Pkt. 5c., oz. IOc., 1/4 lb. 25c., 1b. $90 \mathrm{c}$.

Sweetheart. Medium early, slightly oblong, thick rind, flesh sweet and delicious. Pkt. 5c., oz. Ioc., 1/4 1b. $25 \mathrm{c} ., 1 \mathrm{~b} .90 \mathrm{c}$.

Alabama Sweet. Large, oblong form; firm, dark green, slightly striped rind. Flesh bright red, and good flavor. Seeds are white. Pkt. 5c., oz. IOc., $1 / 4$ 1b. $25 \mathrm{c}$., 1b. $90 \mathrm{c}$

Dixie. Very popular; large, striped and oblong shape; flesh red and sweet. Pkt. 5c., oz. IOc., 1/4 lb. 25c., 1b. $90 \mathrm{c}$.

Cole's Early. Medium size, oblong, striped and mottled; flesh red, solid and sweet. Pkt. 5c., oz. IOc., $1 / 4$ 1b. 25 c., 1b. $90 \mathrm{c}$.

Ice Cream (White Seed). Oblong, with dark mottled skin; flesh pink and sweet. Pkt. 5c., oz. IOc., 1/4 lb. 25 c., 1b. $90 \mathrm{c}$.

Mountain Sweet. Large, oval-shaped; skin green; flesh red, solid and sweet. Pkt. 5c., oz. Ioc., 1/4 lb. $25 \mathrm{c} ., 1 \mathrm{~b} .90 \mathrm{c}$.

Phinney's Early. Oblong-shaped; very early; thin rind; delicious flavor. Pkt. 5c., Oz. IOc., 1/4 lb. $25 \mathrm{c}$., 1b. $90 \mathrm{c}$.

Early Fordhook. Very early and fine quality; nearly round; mottled green. Pkt. $5 \mathrm{c}$., oz. IOc., $1 / 4$ lb. $25 \mathrm{c}$., 1b. $90 \mathrm{c}$.

Kleckley Sweets. Long; dark green skin; bright red flesh of luscious sweetness. Pkt. 5c., oz. IOc., 1/4 lb. $25 \mathrm{c} ., 1 \mathrm{~b} .90 \mathrm{c}$.

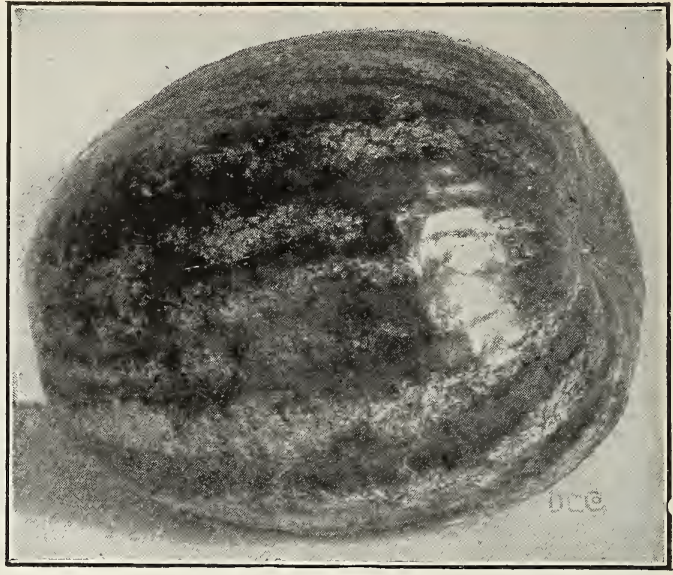

Cole's Early Watermelon

Tom Watson. Large, oblong, dark green skin, with thick netting. Flesh bright red, delicious flavor. Pkt. 5c., Oz. IOc., 1/4 lb. 25c., 1b. 90c.

Florida Favorite. Large, oblong and green mottled; flavor is excellent. Pkt. 5c., oz. IOc., $1 / 4 \mathrm{lb}$. $25 \mathrm{c}$., 1b. $90 \mathrm{c}$.

Halbert's Honey. A large, oblong variety, especially sweet and of delicious flavor. Pkt. 5c., oz. IOc., $1 / 4$ 1b. $25 \mathrm{c}$., 1b. $90 \mathrm{c}$.

Citron. Used exclusively for preserves and pickling. Pkt. 5c., Oz. IOc., 1/4 lb. 25c., 1b. $90 \mathrm{c}$.

\section{MUSTARD}

The leaves of Mustard make excellent greens, of sharp, pungent flavor, and are cooked the same as Spinach, or Beet Greens. Sow the seed in early Spring, and at intervals during the Summer.

$$
\text { One ounce will sow } 50 \text { feet of drill. }
$$

White English. Oz. 5c., $1 / 4$ 1b. I5c., 1b. 35c.

Chinese Curled. Pkt. 5c., oz. IOc., 1/4 1b. 25c., 1b. $70 \mathrm{c}$.

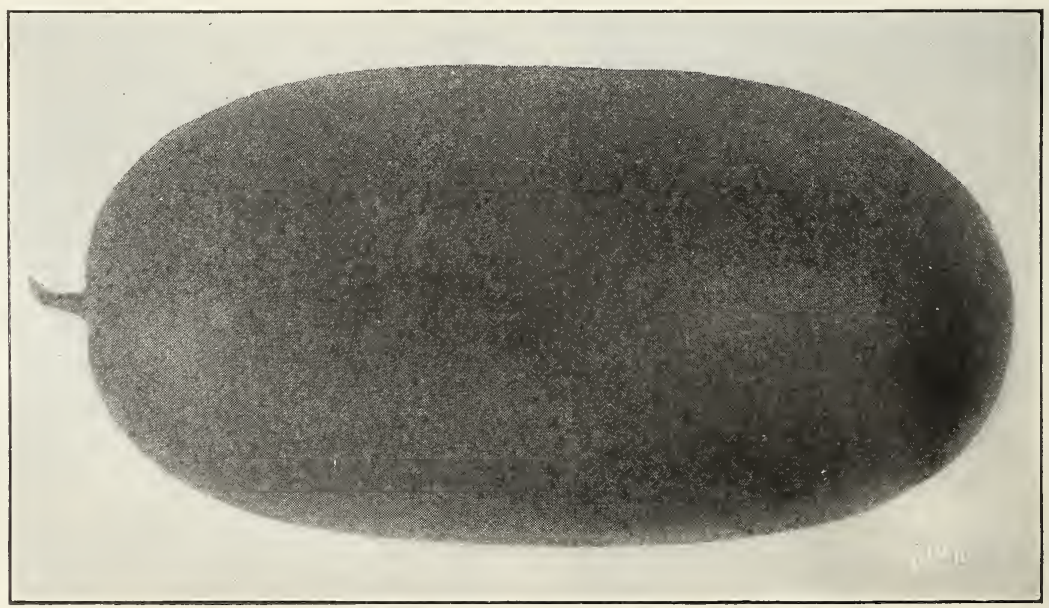

Tom Watson Watermelon 


\section{ONION}

Culture.-The most important thing in growing Onions is to have good seed-seed that will come up and produce the variety you want. Being growers and farmers ourselves we fully appreciate the importance of this item, and our customers may have perfect confidence that the seed we send them will be right in every particular. The soil for Onions should be a rich loam, thoroughly enriched with well rotted manure, and the soil well pulverized before sowing the seed. Sow the seed as early in the Spring as ground can be worked, in drills I4 inches apart, covering one-quarter to one-half inch. Begin cultivating as soon as rows can be plainly seen, and keep them clean, for if Onions once get choked by weeds they never produce so good, or full a crop. A top dressing of wood ashes applied after second weeding and cultivated in, is beneficial.

\section{One ounce will sow roo feet of drill; $5 \mathrm{lbs}$. to the acre.}

Southport Red Globe. A large, globe-shaped, bright deep red variety; a late sort and excellent keeper. Pkt. 5c., oz. 20c., $1 / 4$ lb. 7 oc., 1b. $\$ 2.50$.

Extra Early Red Flat. A very early, flat variety, with dark, purplish-red skin; forms a solid, hard bulb. A good keeper. Pkt. 5c., oz. 20c., 1/4 lb. $70 \mathrm{c}$., lb. $\$ 2.50$.

Wethersfield Large Red. The best known and most widely used red variety. It is a thick, flattishshaped Onion with firm flesh; a good keeper and heavy yielder. Pkt. $5 \mathrm{c}$., oz. 20c., $1 / 4$ lb. 7oc. lb. $\$ 2.50$.

Southport Yellow Globe. A fine orange-yellow, globe-shaped variety. Is a heavy cropper and forms a good keeping, hard bulb. Pkt. $5 \mathrm{c}$, , oz. $20 c$., $1 / 4$ lb. $70 \mathrm{co}$., lb. $\$ 2.50$

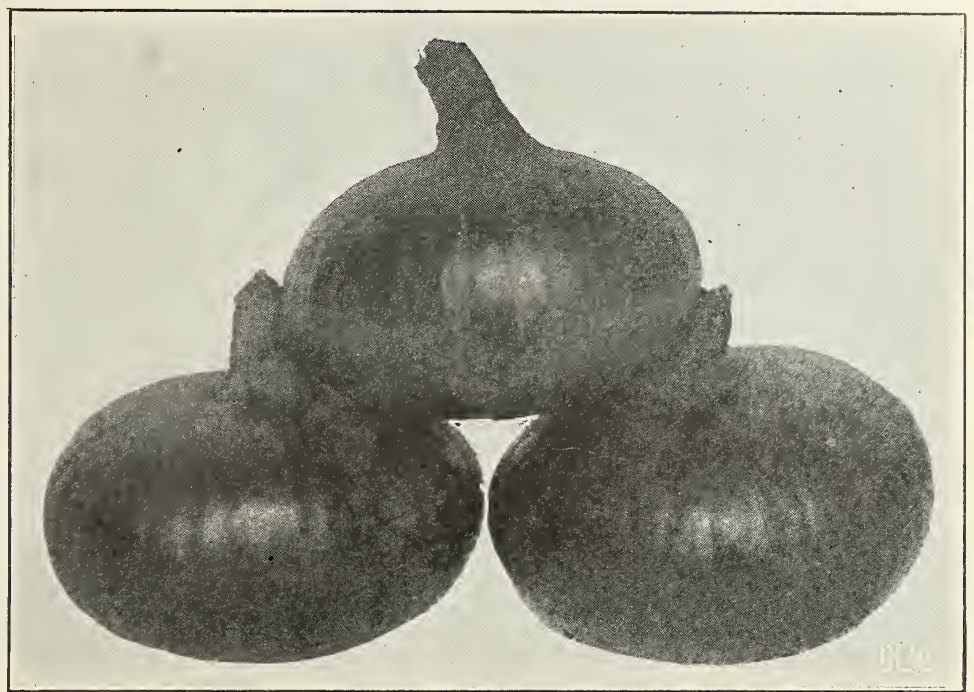

Red Wethersfield Onion

Danvers Yellow Flat. A bright orange-yellow flat Onion; yields large crops, and is a good keeper. Is a good variety to transplant to get early Onions. Pkt. 5c., Oz. 20 c., $1 / 4$ lb. $70 c$., 1b. $\$ 2.50$.

Yellow Globe Danvers. A popular yellow, round Onion for market and shipping. Is almost ball-shaped but a trifle flattened at both ends. It is a heavy cropper, and a firm, hard-fleshed variety. Pkt. $5 \mathrm{c}$., oz. 2Oc., $1 / 4$ lb. 7oc., lb. $\$ 2.50$.

Australian Brown. A half-globe-shaped, brown colored, very productive and noted for its good keeping qualities. Pkt. 5c., oz. I 5c., $1 / 4$ lb. 50c., lb. $\$ 2.00$.

Ohio Yellow Globe. One of the best of the Yellow Globe varieties. The flesh is firm and fine grained; the bulbs are uniform in size and shape and all fine keepers. Pkt. 5c., Oz. 20c., 1/4 lb. 7 Oc., lb. $\$ 2.50$.

Prizetaker. A very large, globe-shaped variety, with yellow skin and white flesh of mild flavor. A heavy cropper and a good keeping Onion. Pkt. 5C., Oz. 20c., $1 / 4 \mathrm{lb}$. $70 \mathrm{co}, 1 \mathrm{~b} . \$ 2.50$.

Southport White Globe. A pure white, globe-shaped variety. Its pearl-white flesh is fine grained and mild. Pkt. 5c., oz. 25 c., $1 / 4$ lb. 85 c., lb. $\$ 3.20$.

White Portugal, or Silver Skin. A white, flat Onion, very hard and firm and an excellent keeper. Is used largely for pickles. Pkt. 5c., oz. $25 \mathrm{c} ., 1 / 4$ lb. $80 \mathrm{c}$, 1b. $\$ 3.00$.

If large quantities of Onion Seed are wanted write for special price. 


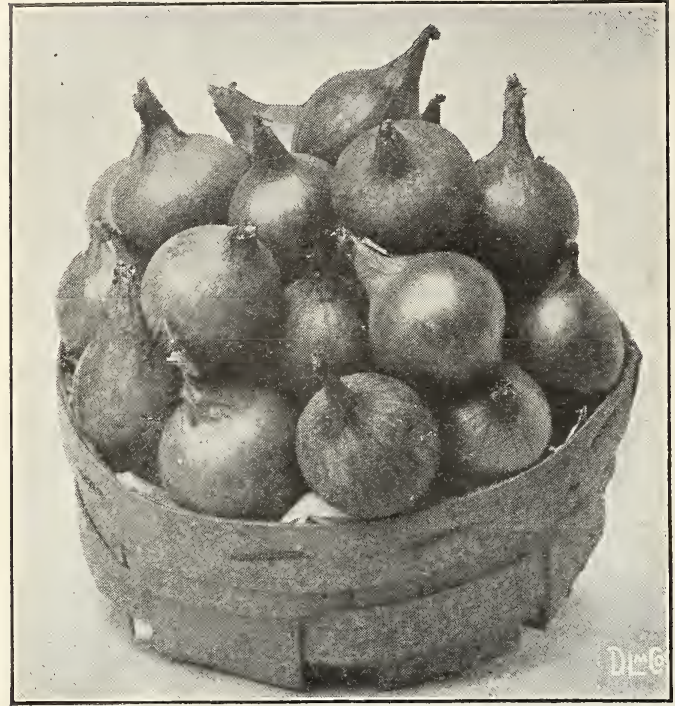

Onion Sets

\section{ONION SETS}

Culture.-These are the very small-sized Onions that have been grown from seed and wintered over. Set them out in the open ground as early in the Spring as ground can be worked, in drills I 4 inches avart, and 4 inches in the row. Keep well cultivated, and they will produce large Onions ready for market much earlier than can be raised from seed, and always command much higher prices. They are ready for use as soon as bulbs are of fair size. They may be used green and for bunching. Weight per bus. 32 lbs.

8 to Io bus. (according to size) required for an acre. Add 5c. per lb. for postage, if sent by mail. (Good sound sets are scarce).

Red Sets. 20c. per lb. up to Io lbs.; Io lbs. and over I8c. per $1 \mathrm{~b}$.

Yellow Sets. 20c. per lb. up to Io lbs.; Io lbs. and over, I8c. per lb.

White Sets. 25c. per lb. up to Io lbs.; Io lbs. and over, 2oc. per lb.

Egyptian, or Top Onion. These set out in August or September live in the ground all Winter, and make green bunching Onions for very early Spring use. 2Oc. per lb. up to Io lbs.; Io lbs. and over, I $5 \mathrm{c}$. per $\mathrm{lb}$.

\section{OKRA, or GUMBO}

Culture.-The young seed pods are excellent used in soups, stews, catsups, etc. After danger from frost is past, plant in rows about 3 feet apart, cover about I inch deep, pressing soil down firmly. Thin to about I foot apart in the row. The pods are in best condition to use when from I to 3 inches long.

White Velvet. Of tall growth; pods white, smooth and tender. Pkt. 5c., oz. IOc., $1 / 4$ lb. 20c., lb. 6oc.

Improved Long Green. Pods are long, smooth, green in color, and very tender. Pkt. 5c., oz. Ioc., $1 / 4$ oz. $20 \mathrm{c}$., 1b. 6oc.

Improved Dwarf Green. Grows very stocky and productive. Pods medium length, quite thick and very tender. Pkt. $5 \mathrm{c}$., Oz. IOc., $1 / 4$ lb. 20c., lb. 6oc.

\section{PARSLEY}

Used for garnishing meats, and for flavoring.

Culture.-The seed is very slow to germinate; usually from two to three weeks will elapse after sowing, before the plants make an appearance. To hasten it, soak the seed a few hours in tepid water, and when it swells, sow thickly in shallow drills, about I4 inches apart; cover lightly, and firm the soil on the seed, thin out to 2 or 3 inches in the row. For Winter use, protect in coldframes or a light cellar.

Hamburg Parsley is cultivated for its roots and should be treated in same manner as Carrots. One ounce will sow I50 feet of drill.

Champion Moss Curled. The best variety for market and home use; is beautifully crimpled and curled. Pkt. 5c., Oz. I2c., $1 / 4$ lb. 35 c., 1b. $\$ 1.25$.

Plain-leaved. Is stronger in flavor than the curled, and is used for flavoring soups, etc. Pkt. 5 c., oz. I2c., $1 / 4$ lb. 35c., lb. \$I.25.

Hamburg, or Turnip-Rooted. The root, which resembles a small Parsnip, is the edible portion and is used for flavoring soups, etc. Pkt. 5c., oz. I2c., $1 / 4$ lb. 35c., lb. $\$ 1.25$.

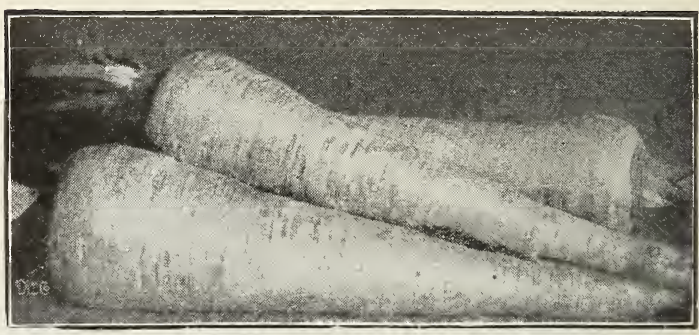

Champion Hollow Crown Parsnip

\section{PARSNIP}

Culture.-As this is so slow to germinate, plant only new seed and sow very liberally. Parsnips do best in a deep, rich, sandy loam, but will make good roots on any soil that is deep and mellow and moderately rich. Sow early in Spring in rows 14 to 16 inches apart, cover not over half an inch and press the earth firmly on the seed. Thin out to 4 inches in the rows. Parsnips are improved by frost, therefore part of the crop should be left out in the ground over Winter.

An ounce for 150 feet of drill; 4 to 5 lbs. for an acre.

Champion Hollow Crown. An improved strain of Hollow Crown. This has been selected for its handsome form, whiteness of skin and flesh, good size and freedom from tendency to side roots and for its superior quality. Pkt. 5c., oz. I0c., $1 / 1 / 1$ lb. 30c., lb. \$1.00.

Champion M sss Curled Parsley 


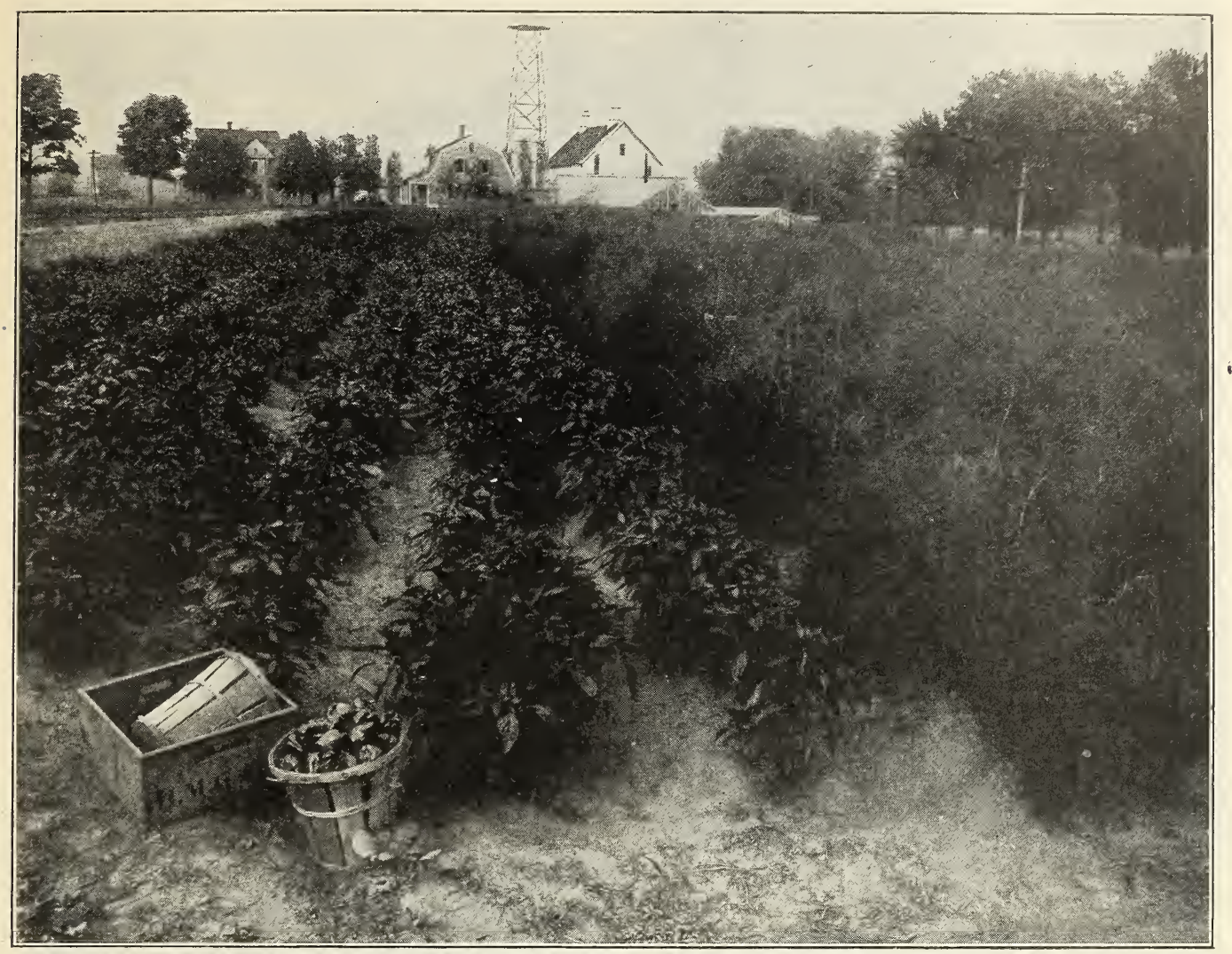

Another partial view of Mr. Anders Christensen's Vegetable Garden Marketing a field of Pimento Peppers

\section{PEPPER}

Culture.-Sow seed in the hotbed in April, or in a warm, sheltered spot out of doors in May. When weather becomes settled and warm, transplant into rows 2 feet apart and 18 inches in the row. Cultivate often and draw up the earth a little to support the stems. (Seed very scarce.)

One ounce will produce about 2000 plants.

Sweet Italian. An exceedingly mild sort that matures very early and is very prolific. They resemble Ruby King in shape but are slightly larger; flesh thick, sweet and mild flavored. Pkt. 5c., oz. 40c., 1/4 lb. $\$ 1.45,1 b . \$ 5.60$.

Neapolitan Large Early. The most productive of all large Peppers and decidedly the earliest. No other large Pepper develops so quickly. They are borne upright, skin and flesh are bright red; they are thick meated and sweet and "mild as an apple." Pkt. 5c., oz. 4 OC., $1 / 4$ lb. $\$$ I. $45,1 \mathrm{~b}$. $\$ 5.60$.

Pimento. A very thick-fleshed, heart-shaped, smooth, mild, crimson sort, extensively grown by canners for pimentoes and pickles and very desirable for salads. It is a good sort for market gardeners and should be planted in every garden where a delicious sweetflavored Pepper is wanted both for salads and for stuffing. Pkt. 5c., oz. 4Oc., 1/4 lb. \$I.45, lb. \$5.6o.

Ruby Giant. A cross between Chinese Giant and Ruby King; has the good qualities of both and makes a fine market gardener's variety. Pkt. 5c., oz. 40c., $1 / 4$ lb. $\$$ r. 45, lb. $\$ 5.60$.

Chinese Giant. The appearance of this Pepper is most striking and attractive and it sells on sight. It is of monstrous size and flesh is thick and meaty and extremely mild; color brilliant scarlet. Pkt. 5c., oz. 5 oc., $1 / 4$ lb. $\$$ I.75.
Long Red Cayenne. A strong, pungent variety, having long pointed fruit, which is bright red when ripe. Pkt. 5c., oz. 4 OOc., $1 / 4$ lb. $\$ 1.45,1 b . \$ 5.60$.

Large Bull Nose, or Bell. A popular variety for stuffing, fruit large, round and blocky. The color is deep green when young, but when ripe is a glossy red. Pkt. 5c., oz. 4 oc., $1 / 4$ lb. \$1.45, lb. \$5.6o.

Ruby King. This variety grows to a large size. When ripe it is a handsome ruby red color. Its flesh is thick and mild. Very desirable for stuffing. Pkt. 5c., oz. 4Oc., $1 / 4$ lb. $\$$ I. 45 , lb. $\$ 5.6$ o.

Sweet Mountain. Resembles Bull Nose in size, shape and color, but is hotter in flavor, although pleasant to the taste. Is much esteemed for pickling and stuffing. Pkt. 5c., oz. 40c., 1/4 lb. \$I.45, lb. \$5.6o.

Anaheim Chili. This is one of the hottest Peppers grown. In size is about 2 inches across the top, tapering to a point and about 6 inches long; bright red when ripe. Pkt. 5c., oz. 4 oc., $1 / 4$ lb. $\$$ I. 45,1 b. $\$ 5.60$.

Sweet Upright. Plants of medium height and bear the Peppers upright, instead of drooping. They are medium size, just right for stuffing and frying. The Peppers are sweet and mild and even the seeds may be eaten raw. Pkt. 5c., oz. 50c., 1/4 lb. \$I.75. 


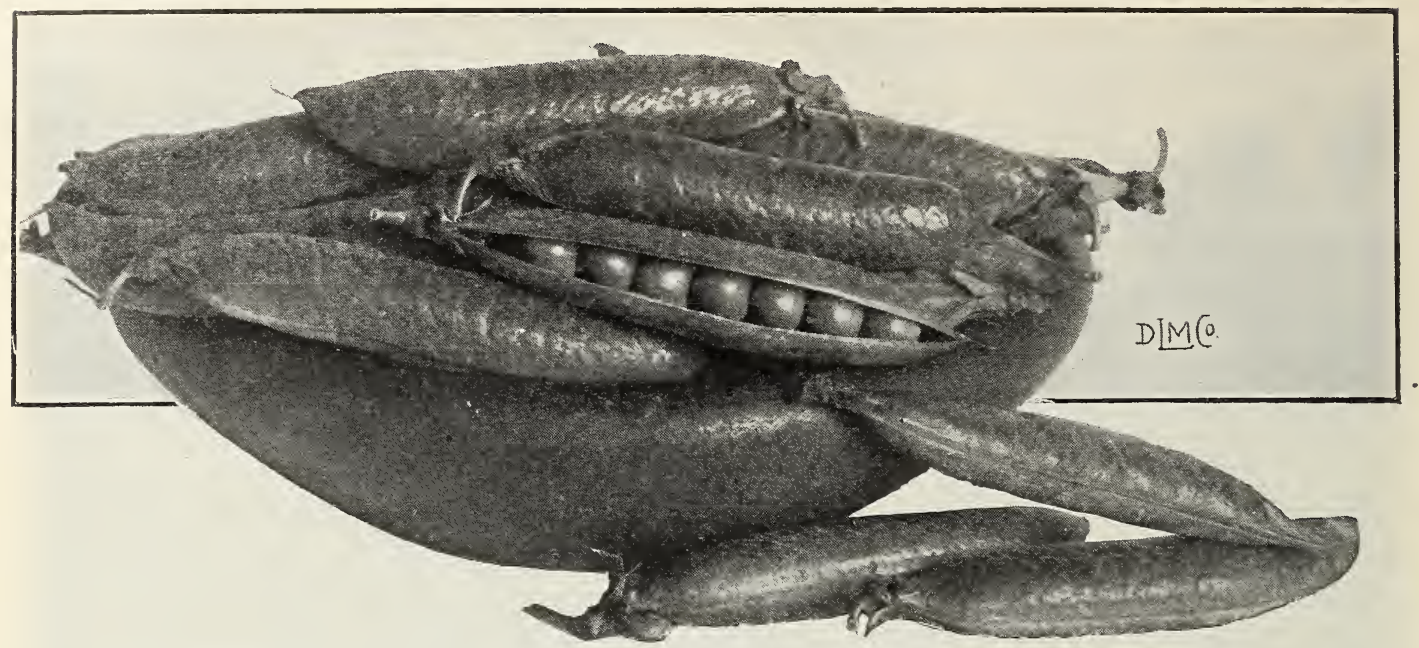

The Pea crop this past season was one of the shortest ever known. Most of the Peas are grown on irrigated lands in the far West, but unfortunately the reservoirs did not fill as usual and it was impossible to irrigate, and Pea vines dried up in the field with pods only half filled or not filled at all. Many fields were entire failures. Our supply is very short. We advise ordering early.

\section{PEAS}

Culture.-For First Early crop sow the Extra Early Smooth Peas and plant as early as land can be worked. Select a rich, light, sandy soil, and cover lightly, and they will mature quicker and can be cleaned up in two pickings. Wrinkled Peas should be planted thicker, as they are not as hardy as the smooth sorts, but are sweeter and better flavored, and do best in a deep, rich loam. Avoid using coarse, rank manure, as it drives the plants to

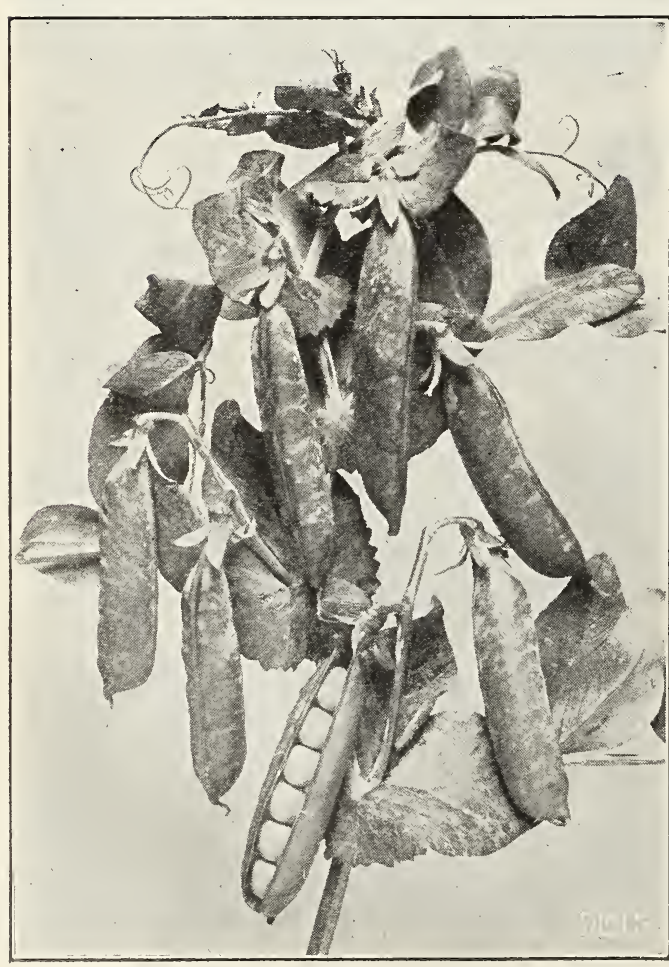

Nott's Excelsior Pea vines without pods. For market crops, sow in rows, $21 / 2$ to 4 feet apart, according to the variety. In the private home garden, where they will be cultivated by hand, the tall sorts may be planted in double rows, 6 or 8 inches apart, sticking brush firmly in the ground between the rows, or they may be planted in single rows 3 feet apart and chicken wire used for the vines to run on. The dwarf sorts may be planted $I \frac{1}{2}$ to 2 feet apart. Cover from 2 to 4 inches, according to the character of the soil and time of planting. Lightest on heavy soil and early planting, and deepest on light soil and late planting. Deep planting has a tendency to prevent mildew and prolongs the bearing season, yet on cold, heavy soil the seed is liable to rot if planted deep. If drills are made 5 inches deep and the seed is covered only I or 2 inches, the earth can be gradually drawn into the trench as the vines grow. In this way a good stand can be had at a good depth. A succession of the same varieties may be had by sowing every two weeks. One quart will plant about roo feet of drill; 2 to 3 bushels for an acre.

One quart will weigh about 2 lbs.

Dwarf Defiance. A splendid large-podded variety of the Stratagem type. Vines strong and heavy with dark green foliage and pods. A very productive main crop sort of high quality. Vines 2 feet high. $1 / 2 \mathrm{lb}$. 28c., I lb. and over 5oc. $1 \mathrm{~b}$.

Peter Pan. One of the very finest of the early large podded, dwarf Peas. Vine and foliage very heavy and dark green. Pods large and well filled with large dark green Peas of superb quality. Vines about ${ }_{5}$ inches high. $1 / 2 \mathrm{lb} .30 \mathrm{c}$., I lb. and over $55 \mathrm{c}$. $1 \mathrm{~b}$.

Quite Content. A new type of the well-known Alderman. Vine and foliage heavy, of a deep green color, pods numerous, deep green, long and broad and containing nine to ten peas of the best quality. Vines $4 \frac{1}{2}$ feet high. $1 / 2 \mathrm{lb}$. $30 \mathrm{c}$., I lb. and over $55 \mathrm{c}$. lb. 


\section{PEAS-Continued}

Extra Early East Hartford. This Pea is a favorite with the market gardeners around Hartford. It is a very early, smooth Pea, with vines growing $21 / 2$ feet high. $1 / 2 \mathrm{lb}$. I $8 \mathrm{c}$., I lb. and over 3oc. $\mathrm{lb}$.

Alaska. Extensively used by canners and market gardeners for first early: It ripens very uniformly; seed is smooth and blue. Vines 2 feet high. $1 / 2 \mathrm{lb}$. .I8c., I lb. and over 3oc. lb.

First and Best. One of the first earlies. Very productive, and uniform in ripening; seed round and smooth. Vines $2 \frac{1}{2}$ feet high. $1 / 2 \mathrm{lb}$. I $8 \mathrm{c}$., I lb. and over 30c. $1 \mathrm{~b}$.

Market Surprise. An extra early, smooth variety of very choice quality. Pods are good size. Vines $2 \frac{1}{2}$ feet high. $1 / 2 \mathrm{lb}$. I $8 \mathrm{c}$., I lb. and over $30 \mathrm{c}$. $\mathrm{lb}$.

American Wonder. An extra early dwarf wrinkled Pea. Vines I foot high. $1 / 2 \mathrm{lb}$. $30 \mathrm{c}$., I lb. and over 50c. $1 \mathrm{~b}$.

Premium Gem. An extra early dwarf wrinkled Pea. An limprovement on the Little Gem. Vines I8 inches high. $1 / 2 \mathrm{lb}$. $30 \mathrm{oc}$., I lb. and over $50 \mathrm{oc}$ lb.

Nott's Excelsior. One of the earliest and best of the dwarf wrinkled varieties and the most used. Vines I 5 inches high. $1 / 2 \mathrm{lb}$. $30 \mathrm{co}$, I lb. and over $5 \mathrm{oc}$. $\mathrm{lb}$.

Little Marvel. A fine new variety of dwarf wrinkled Peas. Vines average 15 inches in height, and are heavily set with large pods, frequently borne in pairs. They are fully as early as Wonder, or Nott's Excelsior, while pods are larger and vines produce a heavier crop. Crop failed.

White Canada Field. For fodder and plowing under. Lb. Ioc., Io lbs. and over $7 \mathrm{c}$. $1 \mathrm{~b}$.

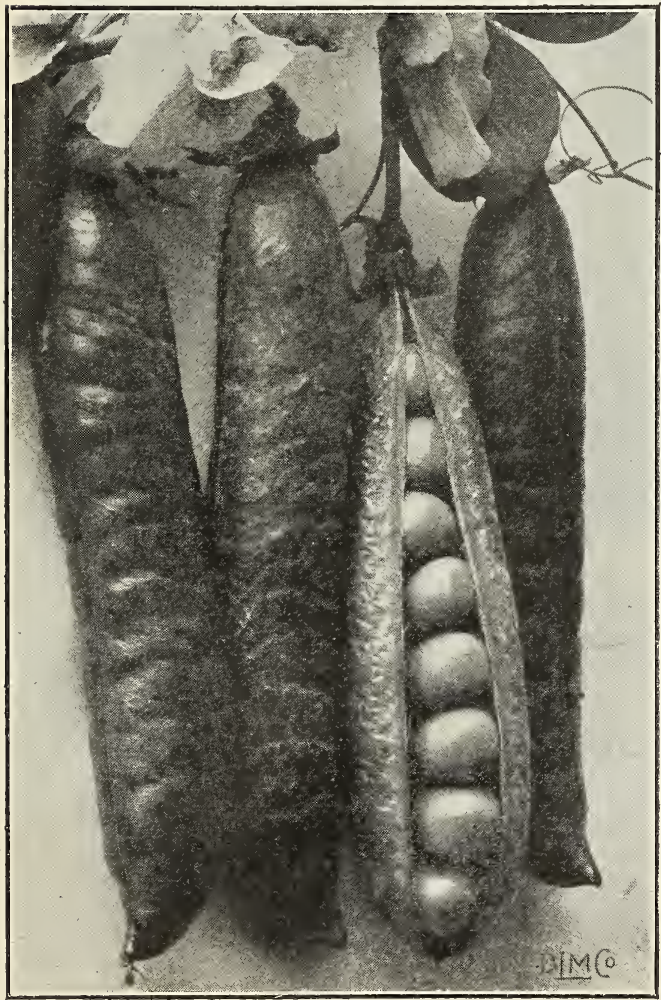

Gradus, or Prosperity Pea

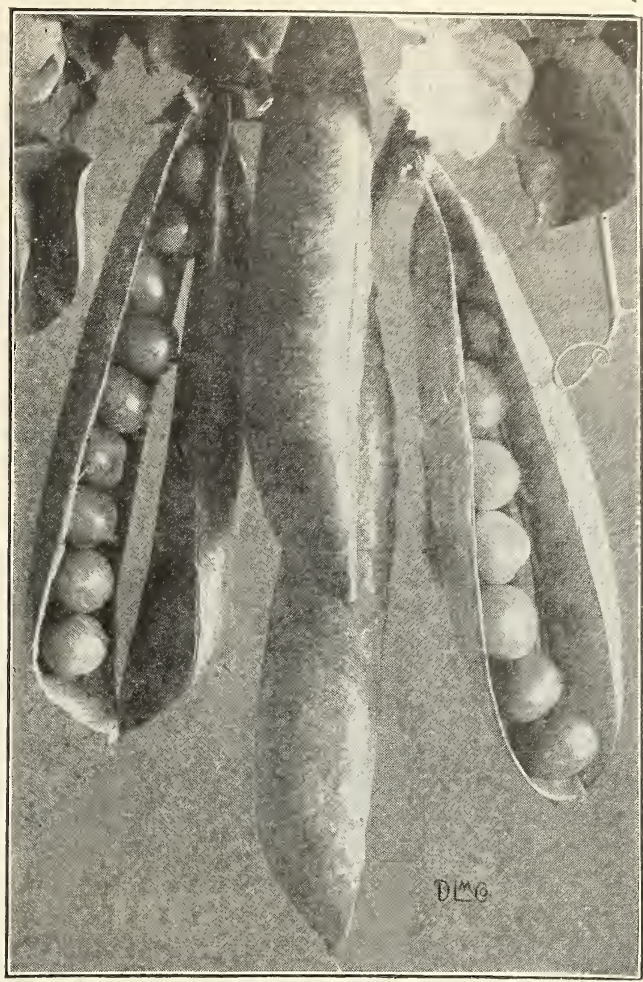

Telephone Pea

Sutton's Excelsior. A new early, dwar, wrinkled Pea, similar in growth to Nott's Excelsior; a few days later, but the pods are much larger, and well filled with delicious, large Peas. Vines i 8 to 20 inches high. $1 / 2 \mathrm{lb} .30 \mathrm{c}$., I lb. and over 50c. $\mathrm{lb}$.

Early Morn. This new variety is claimed by the grower who introduced it to be an improvement on the Gradus, which it closely resembles in every respect. A desirable variety; wrinkled. Vines 3 feet high. $1 / 2 \mathrm{lb}$. $30 \mathrm{c}$., I lb. and over $55 \mathrm{c}$. $1 \mathrm{~b}$.

Laxtonian. One of the largest podded of the early dwarf Peas. Dark green pods similar to Gradus in shape, and nearly as large in size, and mature a little earlier. Vines vigorous and productive, averaging I5 to I 8 inches high. $1 / 2 \mathrm{lb}$. 30c., I $1 \mathrm{~b}$. and over $55 \mathrm{c} .1 \mathrm{~b}$.

McLean's Advancer. A favorite second early; wrinkled. Fine quality. Vines 30 inches high. $1 / 2$ lb. $25 \mathrm{c}$., I lb. and over $45 \mathrm{c}$. $\mathrm{lb}$.

Thomas Laxton. Very similar to Gradus in growth, earliness and foliage. A wrinkled Pea, more hardy and surer cropper than Gradus; pods fully as large, but are blunt at the ends; well filled with large Peas of finest quality. Vines 3 feet high. 1/2 lb. 30c., I $\mathrm{lb}$. and over $55 \mathrm{c} .1 \mathrm{~b}$.

Gradus, or Prosperity. One of the best of the early, large-podded, wrinkled Peas; only a few days later than Nott's Excelsior, with pods nearly as large as Telephone, filled with large, handsome Peas, tender and sweet. Vines 3 feet high. 1/2 lb. 30c., I lb. and over $55 \mathrm{c} .1 \mathrm{~b}$.

Everbearing. A large, medium early, wrinkled Pea; very prolific and fine quality. Vines $2 \frac{1}{2}$ feet high. $1 / 2 \mathrm{lb} .25 \mathrm{c}$., I lb. and over $45 \mathrm{c}$. $1 \mathrm{~b}$.

Yorkshire Hero. A hardy and prolific, medium early wrinkled Pea. Vines $21 / 2$ feet high. $1 / 2 \mathrm{lb} .25 \mathrm{c}$., I lb. and over $45 \mathrm{c} . \mathrm{lb}$.

Stratagem. An excellent wrinkled Pea with medium early, large pods. Vines 20 inches high. $1 / 2 \mathrm{lb}, 25 \mathrm{c}$, I $\mathrm{lb}$. and over $45 \mathrm{c} . \mathrm{lb}$. 


\section{PEAS-Continued}

Horsford's Market Garden. A second early wrinkled Pea. A favorite canning variety; tender and sweet. Vines 30 inches high. $1 / 2$ lb. $25 \mathrm{c}$., I $1 \mathrm{~b}$. and over 45c. $1 \mathrm{~b}$.

Carter's Daisy, or Dwarf Telephone. A medium early, dwarf, wrinkled Pea, with large pods; very prolific, tender and sweet. Vines 20 inches high. $1 / 2$ lb. $28 \mathrm{c}$., I lb. and over 5oc. $1 \mathrm{~b}$.

Dwarf Champion. A dwarf variety of the favorite, Champion of England, retaining its delicious qualities. A wrinkled Pea, with vines $2 \frac{1}{2}$ feet high. $1 / 2$ lb. $25 \mathrm{c}$., I lb. and over $45 \mathrm{c}$. $1 \mathrm{~b}$.

Potlatch. A superior medium, early, dwarf, wrinkled Pea. Pods are large and well filled with large, luscious Peas; a great bearer. Vines 2 feet high. $1 / 2$ lb. $25 \mathrm{c}$., I lb. and over $45 \mathrm{c}$. $1 \mathrm{~b}$.

Telephone. The leading wrinkled Pea with market gardeners. Follows Gradus in earliness. A great cropper; bears very large, well-filled pods of the best quality. Vines 4 feet high. $1 / 2$ lb. 3oc., I lb. and over $55 \mathrm{c} .1 \mathrm{~b}$.
The Admiral. This variety is remarkable for its ability to remain a long time in an edible condition. The vines are about 4 feet high and produce a large quantity of good-sized pods. The peas are of excellent quality. $1 / 2$ lb. $30 \mathrm{c}$., I $1 \mathrm{~b}$. and over $55 \mathrm{c} .1 \mathrm{~b}$.

Alderman. A very large-podded, wrinkled Pea of the Telephone type. An immense bearer; fine quality; medium early. Vines 4 feet high. $1 / 2$ lb. 30c., I lb. and over $55 \mathrm{c}$. $\mathrm{lb}$.

Boston Unrivaled. An improved strain of Telephone. Seed wrinkled. Vines grow $41 / 2$ feet high, filled with large pods and continue in bearing a long time. $1 / 2$ lb. 3Oc., I lb. and over $55 \mathrm{c}$. $1 \mathrm{~b}$.

Champion of England. One of the richest and best flavored Peas grown. A late or main crop variety wrinkled. Vines 5 feet high. $1 / 2$ lb. 30c., I lb. and over $55 \mathrm{c}$. $1 \mathrm{~b}$.

World's Record. A very productive, large podded variety, similar in many ways to Gradus, is slightly earlier, peas tender and sweet. Vines $21 / 2$ feet. $1 / 2$ lb. $30 \mathrm{c}$., I lb. and over $55 \mathrm{c}$. $1 \mathrm{~b}$.

\section{POTATOES}

Culture.-The Potato will thrive in almost any soil or climate. Old sod plowed the previous Fall will produce the most abundant and certain crop. On no other crop are the results from the use of phosphates more manifest than on the Potato. Organic manure promotes rot and other diseases, while commercial fertilizers prevent them, and will grow smooth, fine tubers. Plant as early in Spring as ground can be thoroughly worked, in rows $2 \frac{1}{2}$ feet apart, and 15 to I 8 inches apart in the row. Cut one or two eyes from the surface to the center of the tuber, and plant in each hill; cover 3 or 4 inches. Cultivate frequently from the time the young plants appear until they blossom. Seed should be renewed every year or two.

From 8 to Io bushels required to plant an acre.

\section{Potatoes are sent at purchaser's expense}

If more than one sack is wanted, write for special prices.

Our prices for Potatoes will always be found as low as the market will permit; but, on account of fluctuations in values, which we cannot anticipate at the time our catalogue is issued, prices are subject to change.

Early Six Weeks. Extra early. Cook well before it is fully grown. $\mathrm{Pk}$. $\$ \mathrm{I} . \mathrm{I} 5$, bus. $\$ 3.25$, sack of I65 lbs. $\$ 7.50$.

Early Spaulding Rose. An Improved Early Rose. A large early Potato, heavy yeilder; fine quality. Pk. $\$$ I.I 5 , bus. $\$ 3.25$, Sack of I65 lbs. $\$ 7.50$.

Early Rose. A large Potato maturing early. The popular market sort. Pk. $\$$ I.I5, bus. $\$ 3.25$, sack of I65 lbs. $\$ 7.50$.

New Queen. A good general cropper; nothing better for quality; skin and flesh white. Pk. \$I.I5, bus. $\$ 3.25$, sack of I6 5 lbs. $\$ 7.50$.

Green Mountain. A leader in the market. One of the best yielders, keepers and sellers ever introduced. A fine Potato for home use, as the quality is unsurpassed. Pk. $\$$ I.I 5 , bus. $\$ 3.25$, sack of I6 5 lbs. $\$ 7.50$.

Irish Cobbler. Very early; big yielder; fine quality. Pk. $\$$ I.I 5 , bus. $\$ 3.25$, sack of I65 lbs. $\$ 7.50$.

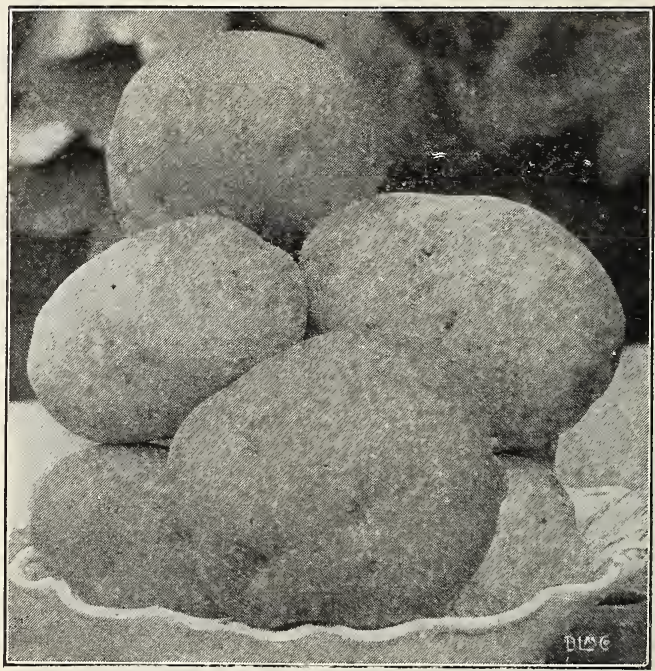

Green Mountain Potatoes

Gold Coin. One of the hardiest, most vigorous in growth, most productive and the best in table quality of all Potatoes; it has proved to be absolutely unequaled for main crop. Pk. \$I.I5, bus. $\$ 3.25$, sack of I65 lbs. $\$ 7.50$.

Beauty of Hebron. One of the most valuable sorts for general use. An excellent keeper. The tubers are large and their flesh is tender. $\mathrm{Pk}$. \$I.I5, bus. $\$ 3.25$, sack of I65 lbs. $\$ 7.50$.

Early Harvest. Extra early. Cooks white and floury; a good cropper. Pk. $\$$ I.I 5 , bus. $\$ 3.25$, sack of 165 lbs. $\$ 7.50$.

Our seed Potatoes are grown in the state of Maine. They are nice stock and entirely free from disease." Seed Potatoes are very scarce and prices are advancing. We advise ordering early, before the supply of choice seed becomes exhausted. 


\section{PUMPKIN}

Culture.-Pumpkins are easily grown in any section. If planted with Corn, drop 2 or 3 seeds in every third or fourth Corn hill at the time of first hoeing. If planted in fields by themselves, drop 5 or 6 seeds in hills 8 or Io feet apart each way. Cover about half an inch and thin out to 3 plants after vines are well started.

One ounce will plant I 5 to 20 hills, 3 lbs. to an acre.

Connecticut Field. A large, yellow field variety; very productive and used mostly for feeding stock. Oz. IOc., $1 / 4$ lb. 25 c., lb. $90 \mathrm{c}$.

Small Sugar. This is the Pumpkin from which the celebrated Yankee Pumpkin pie is made. A small, round, very prolific variety; skin and flesh deep orange yellow. Very fine grained and sweet. Oz. Ioc., $1 / 4$ lb. 25 c., lb. $90 \mathrm{c}$.

Large Cheese, or Kentucky Field. Large, flat and round like a cheese; color of skin deep orange; flesh somewhat lighter. Oz. IOc., 1/4 1b. $25 \mathrm{c} ., 1 \mathrm{~b} .90 \mathrm{c}$.

Striped Cushaw. Resembles in shape the Winter Crookneck Squash. Skin striped, with mottled green bands of creamy white. Rich yellow meat, tender and fine flavored. Pkt. 5c., oz. I5c., $1 / 4 \mathrm{lb}$. $40 c$., lb. $\$ 1.25$.

King of the Mammoths. This is a giant among Pumpkins; sometimes reaching 2 feet or more in diameter, and weighing from Ioo to $250 \mathrm{lbs}$. Salmonorange skin, very thick, bright yellow flesh, fine grained and tender and of excellent quality for pies. Pkt. 5c., oz. I5c., $1 / 4$ lb. 40c., lb. \$I.25.

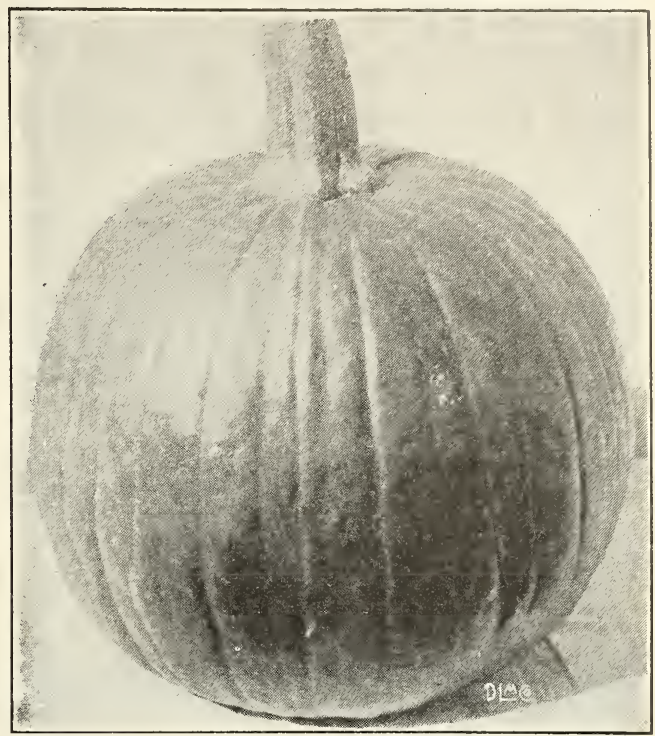

Small Sugar Pumpkin

\section{RADISH}

Culture.--Radishes to be mild, crisp and tender must make a steady, rapid growth; therefore a rich, light, sandy soil is best adapted for their culture. Where possible, give them plenty of water, which forces them along. If it is too dry they are apt to be strong, wormy and pithy. For early use sow in hotbeds on gentle heat, in rows 6 inches apart, and thin enough to prevent crowding. They should be large enough to use in 4 or 5 weeks from time of planting. Plant in the open ground soon as land can be worked, in rows Io to I 2 inches apart. For succession, sow every week or ten days as long as wanted. The Winter varieties should be sown in July or August, taken up before severe frost and stored in a cool cellar, packed in sand for Winter use.

One ounce will sow roo feet of drill.

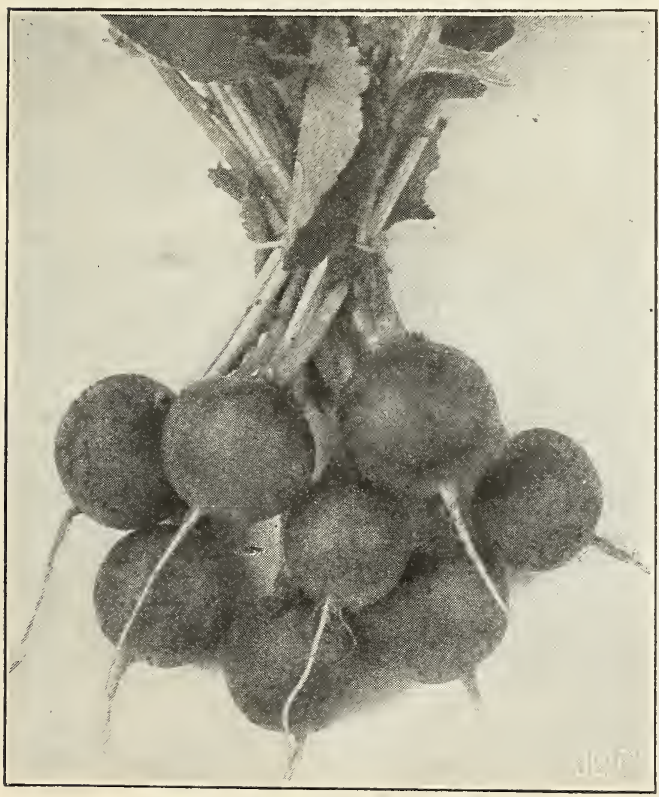

Early Scarlet Globe Radishes
Rosy Gem. For forcing under glass, or open culture; round, deep scarlet on top, blending into white at the bottom. Pkt. 5c., Oz. IOc., 1/4 lb. 35c., 1b. \$I.25.

Scarlet Olive-Shaped. Very early bright scarlet, flesh white and crisp. Excellent for forcing or outdoor culture. Pkt. 5c., oz. IOc., $1 / 4$ lb. 35c., lb. $\$ 1.25$.

California Mammoth. A large white Winter Radish. Roots Io to I2 inches long, and 3 to 4 inches in diameter at the shoulder, tapering regularly to the tip; flesh crisp, firm and decidedly pungent. Pkt. 5c., Oz. IOc., $1 / 4$ lb. 35c., lb. \$1.25.

Early Scarlet Globe. A bright scarlet color. Very popular for forcing. Pkt. 5c., Oz. IOc., 1/4 lb. 35c., lb. \$1.25.

French Breakfast. Excellent for market or forcing. Color bright rose, with white bottom. Pkt. 5c., Oz. IOc., $1 / 4$ lb. 35c., 1b. \$I.25.

Early Scarlet Turnip. A popular Turnip-shaped variety for forcing or outdoor culture. Color deep red. Pkt. 5c. oz. IOc., $1 / 4$ lb. 35c., lb. $\$ 1.25$.

Long Scarlet. Popular long variety. Color red; flesh crisp and firm. Pkt. 5c., oz. IOc., $1 / 4$ lb. 35c. lb. $\$$ I. 25 .

Early Crimson Giant. A very rapid-growing globeshaped Radish, of beautiful crimson-carmine color, and of excellent quality. One of the best varieties for forcing, and desirable for general outdoor planting. Pkt. 5 c., Oz. IOc., $1 / 4$ lb. 35 c., lb. $\$ 1.25$. 


\section{RADISHES-Continued}

White Tipped Scarlet. One of the most popular and attractive globe-shaped Radishes. Color bright rose carmine, with bottom clear white. Pkt. 5c., Oz. IOc., $1 / 4$ lb. 35c., lb. \$1.25.

Early White Turnip. Both skin and flesh white; very mild, tender and crisp. Pkt. $5 \mathrm{c}$., oz. Ioc., $1 / 4 \mathrm{lb} .35 \mathrm{c}$., lb. \$I.25.

Icicle. A quick-growing, long, white variety; very crisp and mild flavor. Pkt. 5c., oz. Ioc., $1 / 4$ lb. 35c., 1b. \$I.25.

White Strasburg. A large, white variety for late Summer use. Thick at the shoulder and tapering to about 5 inches in length. Keeps solid a long time. Pkt. 5c., Oz. IOc., $1 / 4$ lb. 35c., lb. \$1.25.

Giant White Stuttgart. A crisp, late Summer Radish. Very large and top-shaped; both skin and flesh white. - Pkt. 5c., oz. IOc., $1 / 4$ 1b. 35 c.. 1b. $\$$ I.25.

China Rose Winter. A fine keeper for Winter use. Skin rose colored; flesh white and firm, and quite pungent. Pkt. 5c., oz. I5c., 1/4 lb. 40c., 1b. \$I.50.

Round Black Spanish. A Winter Radish. Skin black; flesh white, firm and highly flavored. An excellent sort for Winter. Roots keep a long time. Pkt. 5c., Oz. I 5c., 1/4 lb. 40c., lb. \$I.50.

Long Black Spanish. One of the latest and best keeping of the Winter Radishes. Roots are long, black and very pungent. Pkt. $5 \mathrm{c} .$, oz. I $5 \mathrm{c} ., 1 / 4 \mathrm{lb}$ $40 \mathrm{c}, 1 \mathrm{~b} . \$ \mathrm{I} .50$.

Half-Long Black Spanish. Half-long and grayish black in color; flesh white, firm and crisp. A good keeper for Winter use. Pkt. 5c., oz. I 5c., 1/4 lb. 40c., lb. \$I.50.

\section{RHUBARB}

Culture.-Sow the seed early in April in drills $1 / 2$ inch deep, and thin to 6 inches apart. Transplant to permanent beds the following Spring, or procure single roots by dividing the large roots, and set out 3 or 4 feet apart each way. Ground should be dug and manured well. Do not pull stalks until second year after transplanting roots.

One ounce will produce several hundred plants.

Victoria and Linnæus. Two good sorts. Pkt. 5 c., oz. I5c., $1 / 4$ lb. 50c., lb. $\$$ I. 75 .

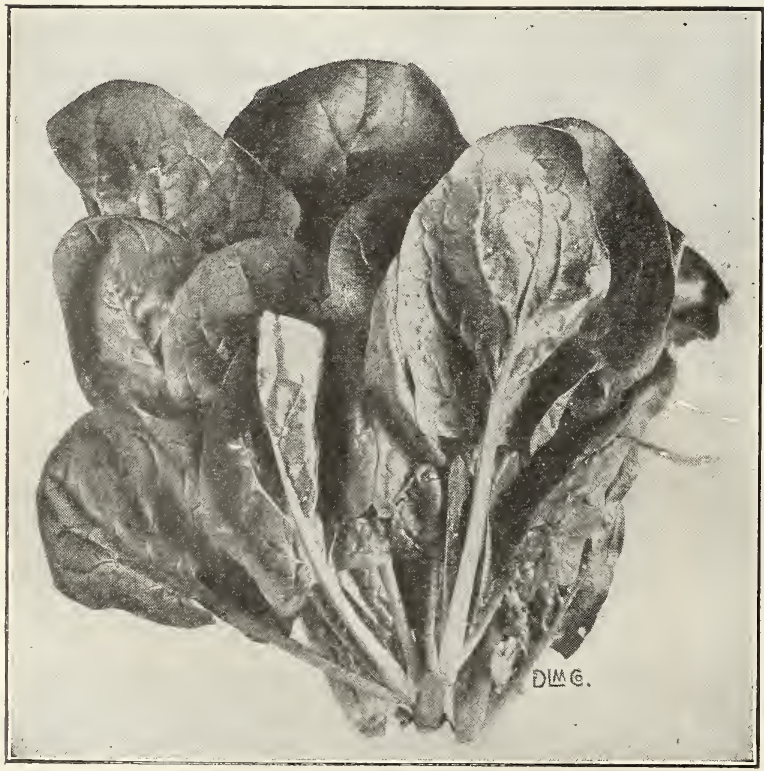

Victoria Spinach

\section{SALSIFY, or VEGETABLE OYSTER}

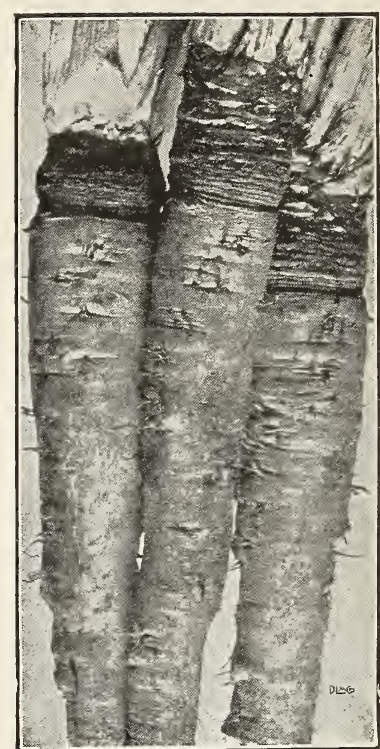

Mammoth Sandwich Island Salsify
Culture.-Plant and culture same as Parsnips. As it is perfectly hardy, it can remain in the ground during the Winter, but it should be dug in the Spring before it commences to sprout. Store a supply for Winter use in a cool cellar, like other root crops.

One ounce will sow I 00 feet of drill.

Mammoth Sandwich Island. This is an improved type of Salsify, superior in every way to the other sorts. The roots may be served boiled as a vegetable or sliced and fried, or they may be made into fritters. It is almost impossible to distinguish them from the oyster fritter. Pkt. 5c., oz. 20c., $1 / 4 \mathrm{lb}$. $60 \mathrm{c}$. lb. $\$ 2.25$.

\section{SPINACH}

The finest "greens" of any plant in cultivation.

Cu!ture.-For Spinach the ground cannot be too rich, yet it will thrive on almost any good soil. Make drills I4 inches apart, use a liberal amount of seed, cover about $1 / 2$ inch, pressing the earth firmly on the seed. For early Spring use, sow in August or September, and protect during the Winter with a light covering of litter, which should be removed as soon as plants begin to grow in the Spring. For Summer use sow as early in Spring as ground can be worked, and for a succession sow every two weeks.

One ounce will sow Ioo feet of drill; 8 to Io lbs. for an acre.

Early Giant Thick Leaf. Produces large, thick, dark green leaves, somewhat crumpled. Oz. 8c., $1 / 4$ lb. 20c., 1b. 75 c.

Large Viroflay. Large, dark green leaves, slightly crumpled. Suitable for either Spring or Fall sowing. Oz. 8c., 1/4 lb. 20c., 1b. $75 \mathrm{c}$.

Victoria. Broad, dark green leaves; remains in prime condition long after nearly all other varieties have run to seed. Oz. $8 \mathrm{c} ., 1 / 4 \mathrm{lb}, 20 \mathrm{c}$. lb. $75 \mathrm{c}$.

Giant Crumpled Leaf. Large, quick-growing sort; leaves crumpled and curled. Oz. 8c., $1 / 4$ lb. 20c., 1b. $75 \mathrm{c}$.

Bloomsdale, or Savoy. Leaves curled and wrinkled. Oz. 8c., 1/4 lb. $20 \mathrm{c}$, lb. $75 \mathrm{c}$.

Prickly, or Winter. For Fall sowing. A very hardy variety. Pkt. $5 \mathrm{c}$., oz. IOc., $1 / 4 \mathrm{lb} .25 \mathrm{c}$., lb. \$1.0o.

New Zealand. Is a distinct variety. Started early in the Spring, the plants will resist heat and dry weather and make a strong growth during the Summer. Pkt. 5c., oz. IOc., $1 / 4 \mathrm{lb}$. 35c., lb. \$1.25.

We can supply in any quantity. If large quantities are wanted, write for special prices. 


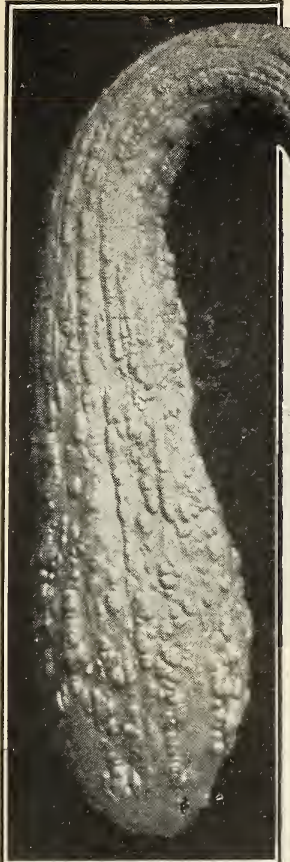

Giant Summer Crookneck Squash

\section{SQUASH}

Culture. - The Squash vine is very tender and so sensitive to cold that it cannot be planted with safety before the middle of May. The hills should be prepared in the same manner as those for Cucumber; the Summer varieties 3 to 4 feet apart each way and the later sorts 6 to 8 feet. Plant 6 or 7 seeds in each hill and cover half an inch; thin to 4 plants after they have obtained their rough leaves and danger from bugs is past.

Of the early varieties, one ounce will plant 40 hills and I2 hills of the late sorts; 4 lbs. early and $6 \mathrm{lbs}$. of the late for an acre.

Vegetable Marrow. An English variety for Summer and Fall use, grows about 9 inches long, oblong in form; shell pale yellow, flesh white. Pkt. 5c., oz. I5c., 1/4 $1 \mathrm{~b}$. 5oc., lb. \$I.50.

Marblehead. Resembles Hubbard in shape, but is earlier, and skin more smooth; shell is blue gray, flesh is orange yellow, sweet and dry. Pkt. 5c., oz. I5c., 1/4 lb. 50c., 1b. \$I.50.

White Bush Scallop. The old "Patty Pan"; white skin and flesh. Very early. Pkt. 5c., oz. IOc., 1/4 1b. 50c., lb. \$I.50.

Yellow Bush Scallop. Similar to White Scallop, but color is yellow. Pkt. 5c., oz. I5c., $1 / 4$ lb. 50c., 1b. \$I.50.

Giant Summer Crookneck. This strain is earlier even than the common small variety and equally tender and sweet, while the Squashes grow to an extra long size. Pkt. 5c., oz. I5c., 1/4 lb. 50c. lb. \$I.50.

Golden Hubbard. The heavily warted skin is of rich orange yellow turning to a deep salmon red when ripened. It is equally as productive and fine in quality as the original Hubbard. Pkt. 5c., oz. I 5c., $1 / 4$ lb. 5oc., lb. $\$$ I.6o.

Boston Marrow. A popular second early Squash for Autumn use; skin thin, reddish yellow; flesh dry, fine-grained and delicious. Pkt. 5c., oz. Ioc. $1 / 4$ lb. 30c., lb. \$I.0o.

\section{Common Summer} Crookneck. This is the small Crookneck, very early and tender. Rich 'golden yellow color; thickly warted. Pkt. 5c., oz. I 5 c., $1 / 4$ lb. 50c., lb. $\$ \mathrm{I} .5^{\circ}$.

Warted Hubbard. Similar in size and quality to the well-known Hubbard, but is more heavily warted. Pkt. 5c., oz. 20c., 1/4 lb. 6oc., lb. $\$ 2.00$.

True Hubbard. This old variety for years has stood the test of all rivals, and is the most popular Winter Squash grown. Hard green shell; flesh bright orange yellow, fine grained, very dry, sweet and of rich flavor. Keeps in perfect condition throughout the Winter Pkt. 5c., oz. 20c., 1/4 lb. 6oc., lb. \$2.00.

Fordhook. This is a very desirable running variety for both Summer and Winter. Oblong in form slightly ridged, smooth, thin, yellow skin; flesh very thick and light straw yellow. Can be used for cooking, while if allowed to ripen on the vines, they will keep well all Winter. Pkt. 5c., oz. I 5c., 1/4 lb. 5oc., lb. $\$ \mathrm{I} .50$.

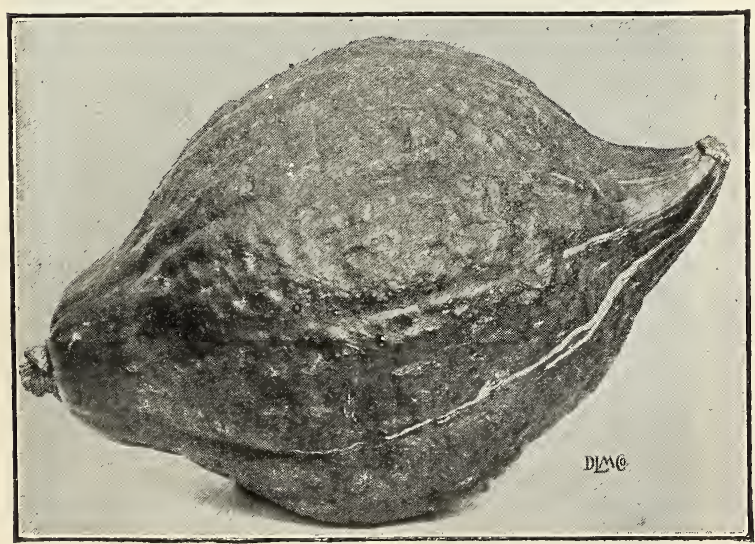

True Hubbard Squash

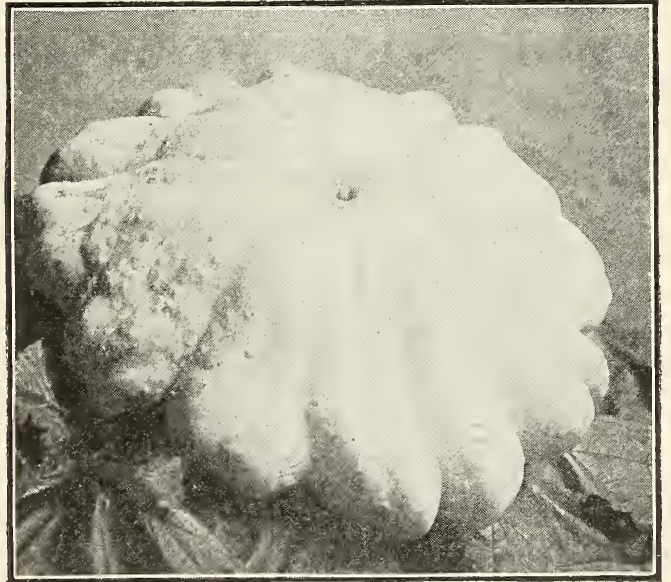

Squash, White Bush Scallop

Essex Hybrid. Valuable for Fall and Winter use. An excellent keeper, of good size; bright orange color; flesh thick, dry and delicious. Pkt. 5c., oz. I5c., $1 / 4$ lb. 50c., 1b. \$I.5O.

Mammoth Chili. Good for stock and exhibitions; often weighing 100 to 200 lbs. Pkt. 5c., oz. 20c., $1 / 4$ lb. 6oc., lb. $\$ 2.00$.

Delicious. A Fall and \$Winter Squash, being excellent at all seasons though it does not acquire its best quality until Winter, when it is very sweet and rich in flavor. Pkt. 5c., oz. 20c., $1 / 4$ lb. 6oc., 1b. $\$ 2.00$.

Winter Crookneck. Excellent for Winter; flesh sweet and of fine flavor. Pkt. 5c., oz. $20 \mathrm{c}$., $1 / 4$ lb. $60 \mathrm{c}$., lb. $\$ 2.00$.

Cocozelle Longe (Italian variety). A Summer variety of compact bush growth. Fruits large, oblong in shape, skin dark green, marbled and mottled with yellow and dark green stripes. Pkt. 5c., Oz. I 5c., 1/4 lb. 50c., lb. \$I.50. 


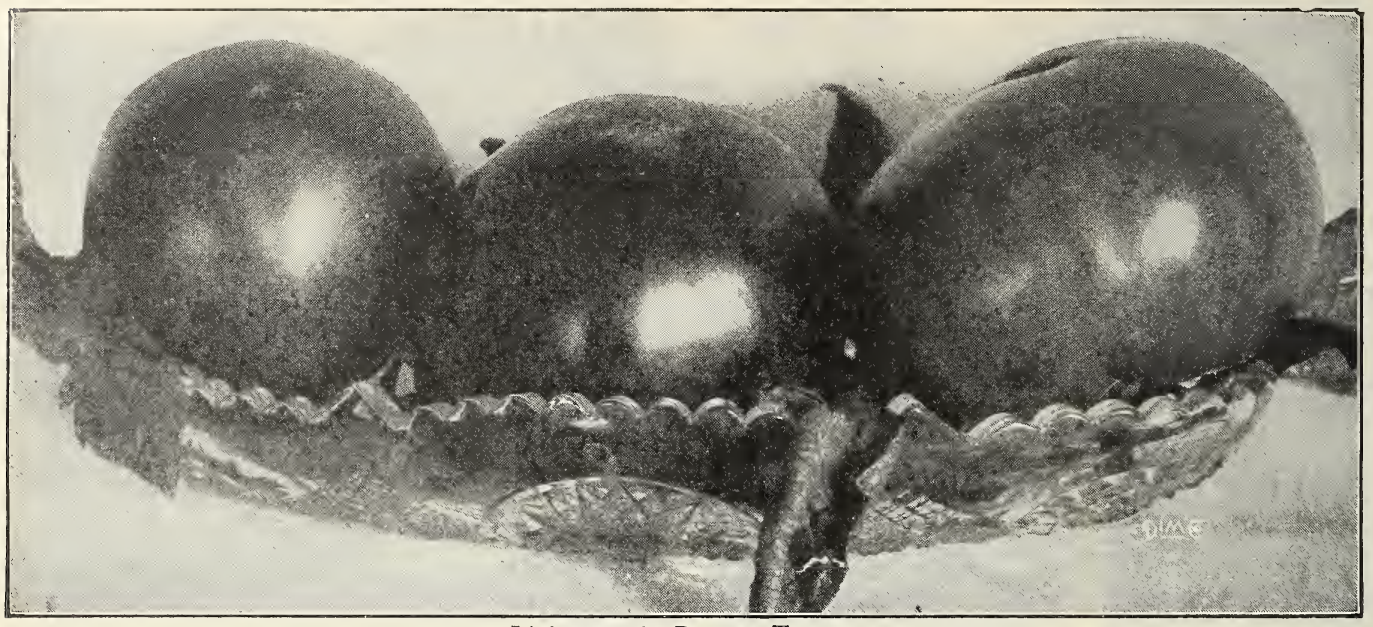

Livingston's Beauty Tomato

\section{TOMATO}

Culture.-Tomatoes do best on a light, warm, not over-rich soil. For early plants sow in March or April in the hotbed, in drills 3 inches apart, 4 or 5 seeds to the inch; cover lightly. Or they may be started in boxes in some sunny window in the house. Transplant when 2 inches high into other hotbeds, or into boxes, or single pots, and place in the frames. Avoid crowding the plants; 4 inches is as near as they should stand in the frames. Lift the sash on warm, sunny days, and 2 or 3 weeks before setting outside, gradually harden them by exposure to the night air. Set 4 feet apart each way in the open ground in May as soon as danger from frost is past. For later use sow in the open ground in May, and transplant when large enough to handle. By training the vines on trellises, or tying them up to stakes, the fruit will ripen better, be of superior quality, and increase their productiveness.

One ounce will produce about $\mathrm{r} 200$ plants.

Bonny Best. An early variety and enormously productive. Fruit produced in clusters in center of plant. Color scarlet red; flesh thick, and fine for slicing. Pkt. 5c., Oz. 20c., 1/4 1b. 75c., 1b. \$3.00.

John Baer. A splendid Tomato for both the market and home garden. Producing beautiful, large bright red, solid Tomatoes early in the season; flesh is thick and meaty, and will not burst open when dead ripe, and have a mild deliciously sweet flavor. Pkt. 5c., oz. 20 c., $1 / 4$ lb. 75 c., lb. $\$ 3.00$.

June Pink. A fine, early pink variety. Pkt. 5c., oz. 20c., $1 / 4$ lb. 75c., lb. $\$ 3.00$.

Chalk's Early Jewel. Medium early; large, smooth, and fine flavor. Pkt. 5c., Oz. 20c., $1 / 4$ lb. $75 \mathrm{c}$., $1 \mathrm{~b}$. $\$ 3.00$.

Earlibell. A new extra early; smooth, beautiful, glossy, scarlet Tomato; ripens uniformly all over; and bears continuously until frost. Pkt. 5 C., Oz. 20c. $1 / 4$ lb. 75 c., lb. $\$ 3.00$.

Sparks' Earliana. A popular extra early, large, red Tomato. Pkt. 5c., oz. 20c., $1 / 4$ lb. 75 c., 1b. $\$ 3.00$.

Early Acme. Standard family Tomato; early, solid, and smooth. Pkt. 5c., oz. 20c., $1 / 4$ lb. 75c., lb. $\$ 3.00$.

Stone. A favorite everywhere; large, solid and smooth; color red. Pkt. 5c., Oz. 20c., $1 / 4$ lb. 75 c., lb. $\$ 3.00$.

Dwarf Champion. Plants grow stiff and upright; early; purplish pink. Pkt. 5c., oz. 25c., 1/4 lb. 90c., lb. $\$ 3.50$.

Dwarf Stone. Plants similar to Dwarf Champion, but fruit is double the size; bright scarlet, solid and smooth. Pkt. 5c., oz. $25 \mathrm{c}$., $1 / 4$ lb. 9oc. 1b. $\$ 3.50$.

Livingston's Beauty. Large, solid, smooth, purplish pink. Pkt. 5c., Oz. 20c., $1 / 4$ lb. 75 c., lb. $\$ 3.00$.

Livingston's Perfection. Bright red, smooth and good size. Pkt. 5c., Oz. 20c., 1/4 lb. $75 \mathrm{c}$., 1b. $\$ 3.00$.

Golden Queen. Large, smooth and pure yellow. Pkt. 5c., Oz. 20c., 1/4 lb. 75c., lb. $\$ 3.00$.

Fordhook First. Solid; deep pink; quite early. Pkt. 5c., oz. $20 c$., $1 / 4$ lb. 75 c., lb $\$ 3$.0o.

Matchless. A good main crop; cardinal red: solid and smooth. Pkt. 5c., oz. 20c., $1 / 4$ lb. 75 c., 1b. $\$ 3.00$.
Ponderosa. Very large, coarse ribbed; deep purple. Pkt. 5c., oz. 25c., 1/4 lb. 9oc., lb. \$3.50.

Trophy. Very large, solid and smooth; bright red. Pkt. 5c., oz. 20c., $1 / 4$ lb. 75 c., lb. $\$ 3.00$.

Yellow Pear. Small, pear-shaped. Good for pickling. Pkt. 5c., oz. 20c., 1/4 lb. 75c., lb. $\$ 3.00$.

Yellow Plum. Small and round. Good for pickling. Pkt. 5c., oz. 20c., 1/4 lb. 75 c., lb. $\$ 3.00$.

Red Plum. Small, round, pickling sort. Pkt. 5c., oz. 20c., 1/4 lb. 75c., 1b. $\$ 3.00$.

Strawberry. Small yellow fruits produced in husks; excellent for preserves. Pkt. 5c., oz. 20c., $1 / 4 \mathrm{lb}$. 75c., lb. $\$ 3.00$.

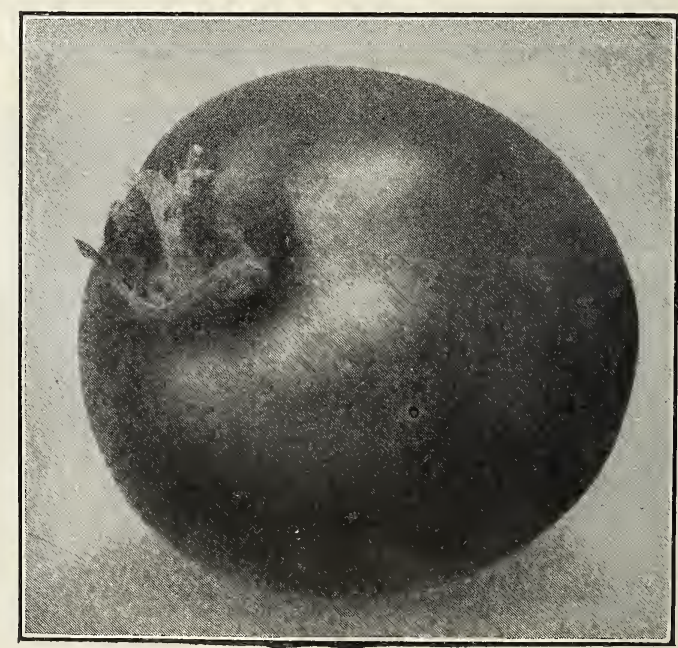

John Bear Tomato 


\section{TURNIP}

Culture.-For the main crop the old rule is good; "Sow Turnips the $25^{\text {th }}$ of July, wet or dry." Yet, fine crops of large, smooth Turnips are often grown from seed sown early in August. New land, plowed the previous Spring, thoroughly harrowed, and given a liberal dressing of some good commercial fertilizer, will produce the best crops. Sow broadcast and rake or brush in. For Summer use sow the early flat varieties, as early as the ground can be worked, in drills I4 inches apart; cover lightly and thin to 6 or 8 inches in the row. Avoid using fresh manure, as it produces rough scabby, worthless Turnips. (Turnip seed very scarce, especially Ruta Baga.)

One ounce will sow Io square rods; one lb. for an acre.

Extra Early Purple Top Milan. Earliest flat Tur. nip; fine table quality. Pkt. 5c., oz. IOc., $1 / 4 \mathrm{lb}$. $25 \mathrm{c}$., lb. $90 \mathrm{c}$.

Extra Early Snowball. Earliest round, white Turnip; fine table quality. Pkt. 5c., oz. IOc., $1 / 4$ lb. $25 \mathrm{c}$., lb. 90c.

White Egg. Handsome oval form; skin white. Pkt. 5c., Oz. IOc., $1 / 4$ lb. 25c., lb. $90 \mathrm{c}$.

Early White Flat Strap-Leaf. A popular early sort. Pkt. 5c., Oz. IOc., $1 / 4$ lb. 25c., 1b. $90 \mathrm{c}$.

Early Red, or Purple Top Strap-Leaf. The standard early. Pkt. 5c., oz. IOc., $1 / 4$ lb. 25c., 1b. $90 \mathrm{c}$.

Long White Cowhorn. Pure white, except at the top. Pkt. 5c., Oz. IOc., 1/4 lb. 25c., 1b. 9oc.

White Globe Strap-Leaf. Early; globe-shaped Pkt. 5c., oz. IOc., $1 / 4$ lb. 25c., 1b. $90 \mathrm{c}$.

Red, or Purple Top White Globe. Fine globeshaped table Turnip. Pkt. 5c., Oz. IOc., 1/4 lb. $25 \mathrm{c}$., lb. $90 \mathrm{c}$.

Yellow Globe. Fine for table or feeding; yellow flesh. Pkt. 5c., Oz. Ioc., $1 / 4$ lb. $25 \mathrm{c}$., lb. $90 \mathrm{c}$.

Yellow Aberdeen. Good for both table and feeding; yellow flesh. Pkt. 5c., oz. IOc., $1 / 4$ lb. 25c., 1b. $90 \mathrm{c}$.

Golden Ball. Very firm and tender; yellow flesh. Pkt. 5c., Oz. IOc., $1 / 4$ 1b. 25 c., 1b. $90 \mathrm{c}$.

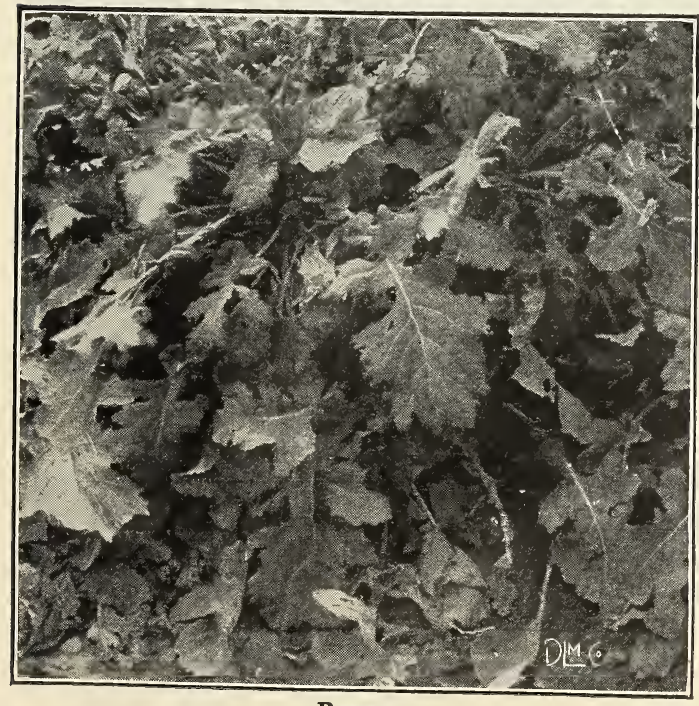

Rape

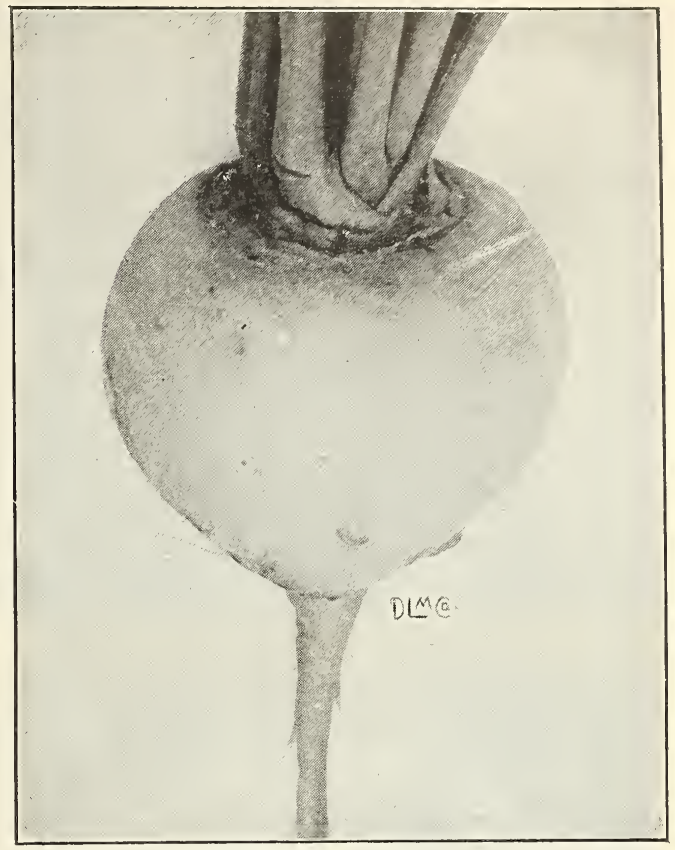

Yellow Globe Turnip

\section{RUTA BAGA, or SWEDE TURNIPS}

One ounce will sow I50 feet of drill; one lb. to the acre.

White Sweet German. Flesh white, fine grained sweet and tender. Pkt. 5c., oz. IOc., 1/4 lb. 30c., lb. $\$$ I.0o.

White French. Popular white-fleshed variety. Pkt. 5c., oz. IOc., $1 / 4$ lb. 30c., lb. $\$$ I.00.

White Rock. One of the best of the white Swedish sorts. Pkt. 5c., oz. IOc., 1/4 lb. 30c., lb. \$I.oo.

American Purple Top Yellow. An improved strain of yellow-fleshed Swede. Pkt. 5c., oz. Ioc., 1/4 lb 30c., lb. \$I.0o.

Long Island Yellow. A fine yellow-fleshed sort; sweet and tender. Plkt. 5c., oz. IOc., 1/4 lb. 30c., 1b. \$I.oo.

\section{TOBACCO}

Connecticut Seed Leaf. Pkt. 5c., oz. 25c., 1/4 1b. 8oc., lb. $\$ 3.00$.

Havana. Pkt. 5c., oz. 20c., 1/4 1b. 75 c., 1b. $\$ 2.50$.

\section{RAPE-Dwarf Essex}

Furnishes excellent pasturage for cattle, sheep and hogs in six weeks from sowing. Its fattening properties are estimated to be twice as great as those of Clover, and for green manuring or for exhausted soils, it has no equal. $1 / 4 \mathrm{lb}$. IOc., I lb. $25 \mathrm{c}$., Io lbs. and over $20 \mathrm{c}$. per $1 \mathrm{~b}$. 


\section{HERBS}

\section{For Culinary and Medicinal Use. (Seed Scarce)}

The garden is not complete without a few Herbs for culinary or medicinal purposes. A small space will give all the Herbs needed in any family.

Culture.-The culture is very simple. The best way is to make a little seed-bed in early Spring, and set the plants out as soon as large enough. The Herbs should be harvested on a dry day, just before they come into full bloom, and dried quickly. They may be hung in a dry, cool loft ogr garret until they are needed for use.

\section{All pkts., 5c. each.}

Anise. For cordials and flavoring. Oz. 25c.

Balm. For culinary purposes. Oz. 25c.

Basil, Sweet. For flavoring. Oz. 25c.

Basilicone (Italian Herb). For culinary purposes. Oz. 25c.

Caraway Seed. For flavoring. Oz. 25c.

Chervil. Used like Parsley. Oz. 25c.

Coriander. Useful for flavoring. Oz. 25c.

Dill. Used in pickles, soups and sauces. Oz. I5c., $1 / 4$ lb. $40 \mathrm{Oc}$.
Fennel, Sweet. The leaves boiled used in sauces. Oz. $25 \mathrm{c}$.

Horehound. For tonic and cough remedies. Oz. 25c.

Lavender. Perfume for oil and water. Oz. 25c.

Sweet Marjoram. For seasoning. Oz. 25c., 1b. \$2.0o.

Summer Savory. Seasoning and flavoring. $\mathrm{O} z .40 \mathrm{c}$

Sage. Leaves are used in dressings and in sauces. Oz. 50c.

Thyme. For seasoning. Oz. 50c.

Wormwood. For medicinal purposes; also beneficial for poultry, planted in poultry yards. Oz. 25c.

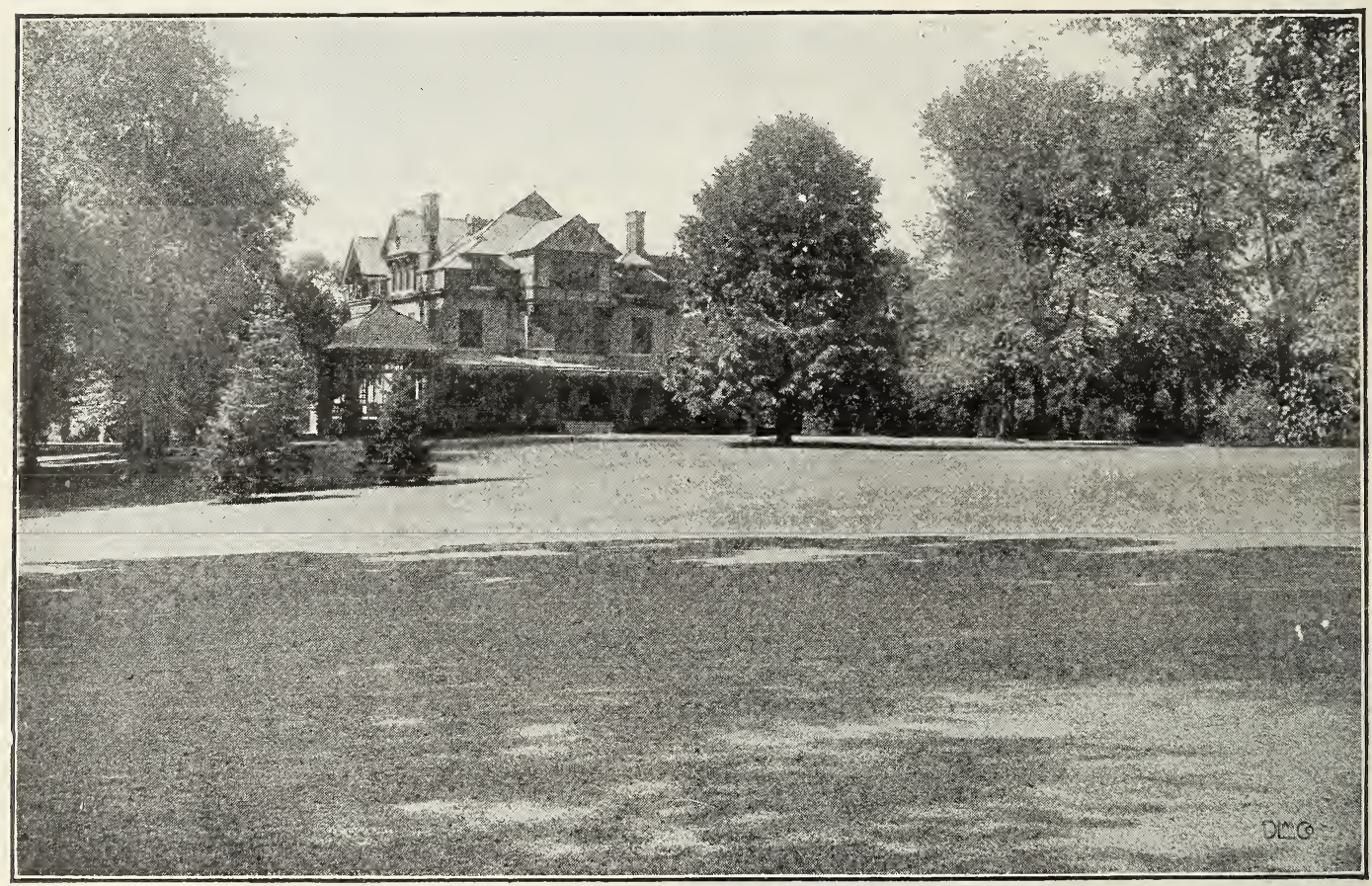

\section{LAWN GRASS SEED}

\section{Beautify your Home with a well kept Lawn}

Culture.-April and May are two good months to lay down a lawn and sow the seed. August and September are also good months, and give the grass time to make a good growth before Winter sets in. Seed does not start well during the hot, dry Midsummer months. After sowing, the ground should be rolled in order to press the seed firmly in the soil, and should be rolled over every Spring as soon as frost is out of the ground. All lawns are benefited by frequent mowing, but do not cut too close in hot, dry weather, or too late in the Fall.

One pound will sow 400 square feet of new ground.

(20 lbs. the bus.)

Hart's Best Mixture.

Central Park Mixture

Shady Place Mixture
Up to 5 llss. per lb. .\$0.25

.35
Up to $10 \mathrm{lbs}$. and over, per $1 \mathrm{~b}$. $\$ 0.20$

.I 8 .30 


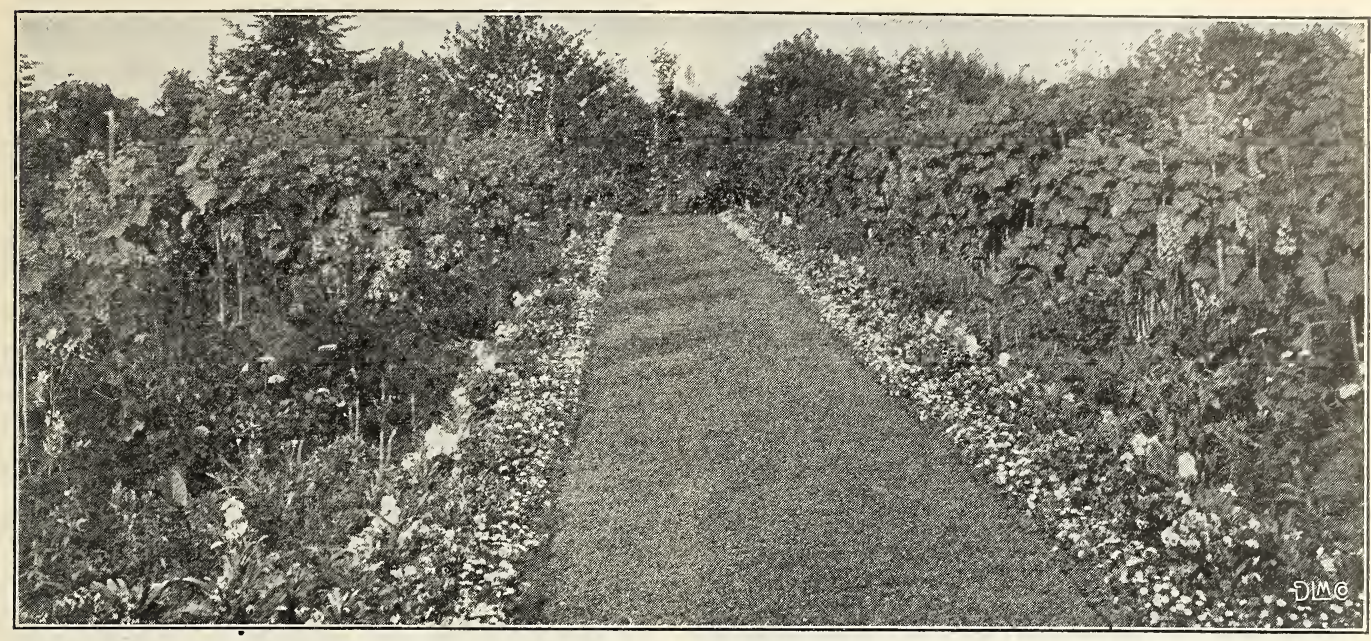

\section{FLOWER SEEDS}

Sowing the Seed. Nine-tenths of the failures in flower culture come from improper treatmert of the seeds and young plants. Do not plant any of the seeds when the ground is wet. Make the surface as fine and smooth as possible. Cover each sort of seed in proportion to its size. The finest seeds should be merely sprinkled on the surface of the ground, and barely covered with finely sifted, light, mellow soil. Press the soil down firmly over the seed; a short piece of board is good for this. For large seeds the depth should be regulated according to the size of the seed. Procure a bit of lath (it would be better if planed smooth), say 2 feet long, press the edge down into the soil evenly, so as to make a groove as deep as the seed is to be planted; scatter the seed along this, allowing 4 or 5 of the larger, to 15 or 20 of the smaller seeds to the space one plant is to occupy when grown; cover the seed by pressing the earth together over it, then turn your lath sideways, and press the soil down firmly and evenly. Shade the rows until after seed is up. It prevents the soil from crusting, and saves the young tender chits from being burned up by the hot sun as they start to come through the ground.

Annuals bloom from seed and die the first year.

Biennials grow from seed the first year, and bloom and die the next, though some varieties bloom the first season when sown early.

Perennials last for several years, blooming annually after the first season, though some varieties will bloom the first season if sown early.

The seeds we offer are all very choice and the best strains.

ACROLINIUM (Everlasting): A pretty half-hardy annual producing white and rose colored double Daisy-like flowers. Pkt. 5c.

AGERATUM, Mixed. Feathery flowers; suitable for pots in Winter or bedding in Summer. Annual. Pkt. 5c., Oz. 25c.

ALYSSUM, Sweet, Little Gem. A favorite annual bearing clusters of white flowers. Plt. $5 \mathrm{C} ., 0 z .25 \mathrm{c}$.

ANTIRRHINUM, or SNAPDRAGON. Showy flowers, blooming the first year from seed.

Tall Mixed. Pkt. 5c., oz. 5oc.

ASTERS. The most popular garden annuals.

Choice Mixed Sorts. Pkt. 5C., oz. $75 \mathrm{c}$.

Choice Named Colors.

White. Plit. Ioc., oz. \$I.oo.

Crimson. Pkt. Ioc., oz. \$1.00.

Pink. Pkt. Ioc., oz. \$I.oo.

Lavender. Pkt. roc., oz. $\$ 1.00$.

Purple. Pkt. Ioc., oz. $\$ 1.00_{\text {, }}$
BALSAM (Lady's Slipper). A favorite garden annual. Camelia-flowered. Choicest Mixed. Pkt. 5c., oz. 5oc.

BALLOON VINE (Love in a Puff). A rapid growing annual climber; flowers white. Pkt. 5c.

CALLIOPSIS. A showy annual, producing large flowers throughout the Summer.

Finest Mixed. Pkt. 5c.

CENTAUREA, or Bachelor's Button (Cornflower). Fine for bedding, vases, etc. Annual.

Choice Mixed. Pkt. 5c., oz. $75 \mathrm{c}$.

CANTERBURY BELL. Biennial.

Single Mixed. Beautiful bell-shaped flower. Pkt. $5 \mathrm{C}$, oz. $75 \mathrm{c}$.

CHRYSANTHEMUM. Single annual. They are Daisy-like in shape, extremely showy, and are mucli used for cut-flower purposes. These annuals are not the Winter-flowering sorts sold by florists, and which are propagated only by division of roots. Mixed colors, Pkt. $5 \mathrm{c}$, 


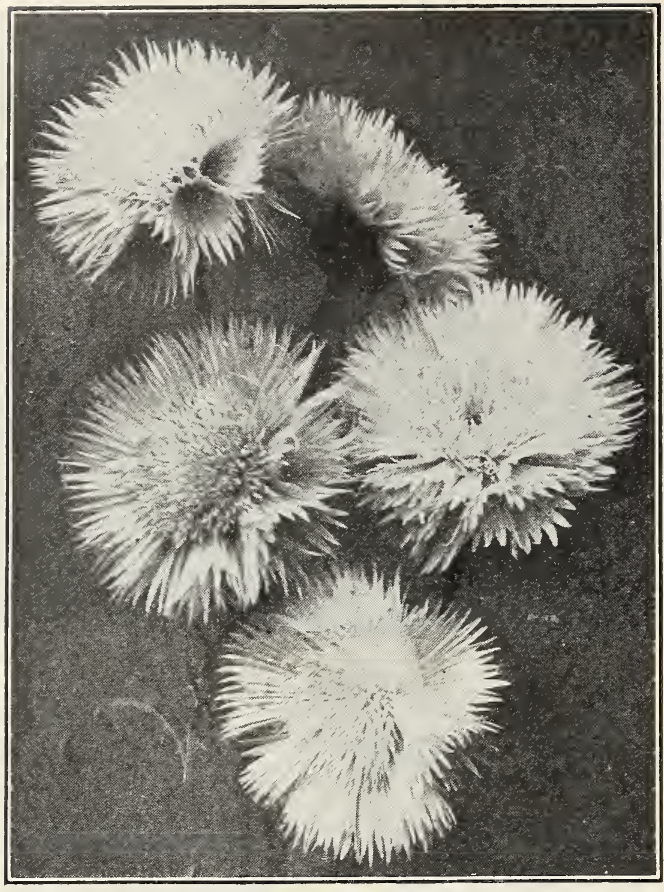

Centaurea, see page 37

CALENDULA. Hardy Annual. I arge double flowers, blossoming all Summer. Pkt. 5c., oz. 5 oc.

CANDYTUFT. Well-known dwarf, profuse flowering garden annua!.

Choicest Dwarf Mixed. Pkt. 5c., oz. 25c.

CANARY BIRD FLOWER. An attractive climber, with beautiful yellow flowers freely produced with tender green foliage. Annual; height ro to 20 feet. Pkt. 5c., oz. $75 \mathrm{c}$.

CARNATION, Marguerite. This superb new dwarf is a double, fragrant flower, and blooms fully from seed the first year. Plit. Ioc., oz. \$I.oo.

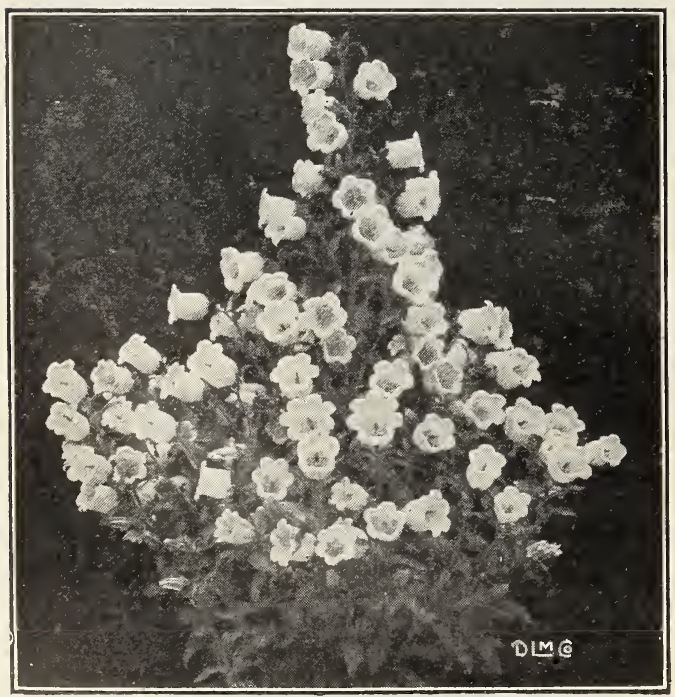

Canterbury Bell, see page 37
CLARKIA. Free-blooming annual.

Choice Mixed. Pkt. 5c.

COLUMBINE, Perennials. Very desirable oldfashioned border flowers, forming large, permanent clumps.

Finest Double Mixed. Pkt. 5c., oz. 5oc.

COSMOS. Large, single flower; 5 to 6 feet high; fine for cutting. Annual.

Mammoth Choice Mixed. Pkt. 5c., oz. 25c.

COCKSCOMB. Produces graceful plumes of bright colors. Annual.

Choice Mixed. Pkt. 5c., oz. 75 c.

CYPRESS VINE. For training upon a light, ornamental trellis, the Cypress Vine cannot be excelled. It has a profusion of scarlet and white star-shaped blossoms. Pkt. 5c., Oz. 5oc.

DAHLIA. Although perennial, these will flower first season if seed is sown early. Grow 4 to $6 \mathrm{ft}$. high.

Large White Single Flowers. Pkt. IOc.

DIGITALIS, or Foxglove. Perennial. Producing long spikes of showy flowers.

Choice Mixed. Pkt. 5c., oz. $75 \mathrm{c}$.

ESCHSCHOLTZIA, or California Poppy. Popular garden annuals, bearing large, saucer-shaped flowers.

Finest Mixed Colors. Pkt. 5c., oz. 5oc.

GAILLARDIA (Blanket Flower). Annual. Will produce a continuous profusion of brilliantly colored flowers from early Summer until late Fall.

Mixed Colors. Pkt. 5c., oz. 5oc.

GODETIA. Very showy, large flower. Annual.

Choice Mixed Colors. Pkt. 5c., oz. $50 \mathrm{c}$.

HELIOTROPE. Flowers are borne in graceful clusters, and are very fragrant, blooms the whole season, a splendid bedding or house plant. Mixed colors. Pkt. $5 \mathrm{C}$.

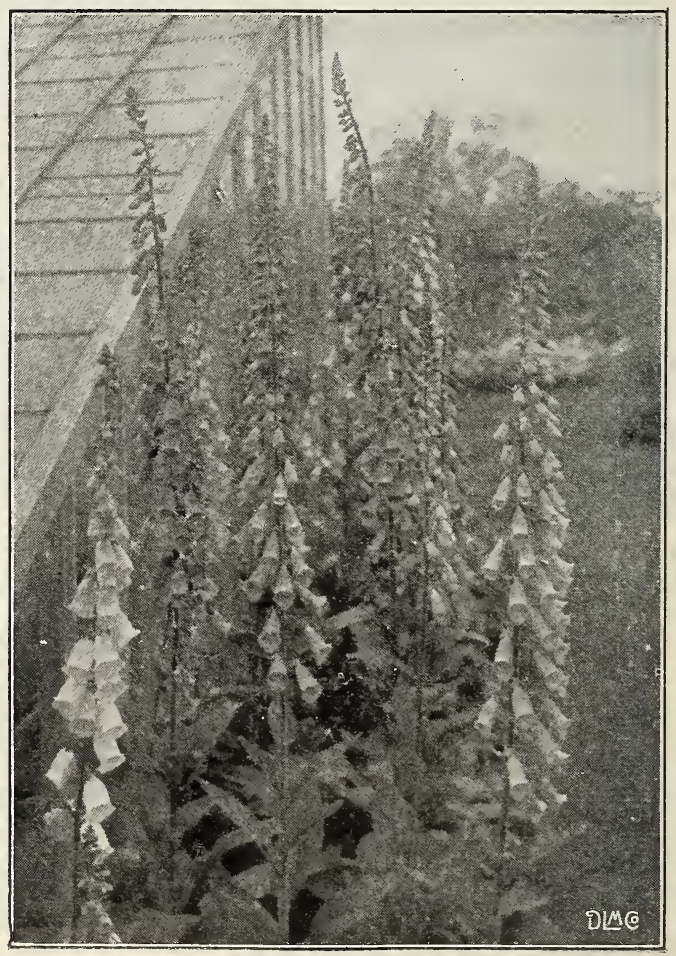

Digitalia 


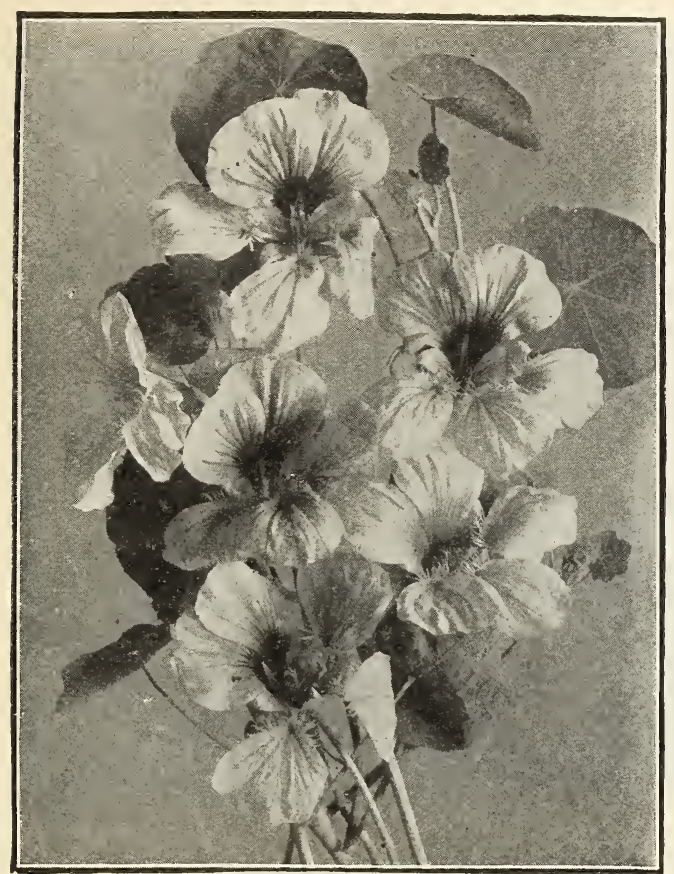

Dwarf Nasturtiums

HIBISCUS africanus. Free blooming, and producing flowers of great size, brilliancy and beauty. Of easy culture, but seed should be planted early and thinned to one foot apart each way. Pkt. 5c.

HOLLYHOCK. Beautiful, hardy plants, with immense flowers on spikes 5 to 6 feet high; flowers second year.

Finest Double Mixed. Pkt. IOc.

LARKSPUR. Well-known annual, producing long spikes of flowers.

Large Flowering Mixed. Pkt. 5c., oz. 5oc.

MARIGOLD. Well-known annual.

Finest French Mixed. Pkt. 5c., oz. $50 \mathrm{c}$

Choice Eldorado. Double Mixed. Pkt. 5c., oz. 5oc.

MIGNONETTE, Sweet. Fragrant garden annuals. Perfection, Fine Selected. Pkt. 5c., oz. 5 oc.

MORNING GLORY. Annual Climbers.

Tall Mixed. Pkt. 5c., oz. Ioc., 1/4 lb. 30c., lb. $90 \mathrm{c}$ Japanese Mixed. Pkt. 5c., oz. Ioc., $1 / 4$ lb. $40 \mathrm{loc}$. lb. \$I.0o.

NASTURTIUM. Beautiful and valuable flowering Summer plants. They require but little care; seed sown early in Spring will produce a profusion of blooms during all the season.

Tall, Mixed Colors. Pkt. 5c., oz. 1oc., 1/4 1b. $25 \mathrm{c}$. Dwarf, Mixed Colors. Pkt. 5c., oz. I Oc., 1/4 lb. $25 \mathrm{c}$.

NIGELLA damascena (Love-in-a-Mist, or Devilin-the-Bush). Very showy blue flowers, with the foliage finely cut which surrounds the flower. Pkt. $5 \mathrm{c}$.

PANSIES. Annual. Most popular flower grown. Fine Mixed. Pkt. 5c., oz. $\$$ I.25.

Large Superb. Choice mixed. Pkt. 5c., oz \$I.50.

PETUNIA. Very popular annual.

Fine Mixed. Pkt. 5c., oz. \$1.00.

Extra Choice Mixed. Pkt. Ioc.

PHLOX, Drummondi. Popular garden annual flowering continuously during the Summer.

Very Choice Mixed. Pkt. 5c., oz. \$1.oo.

POPPY, Shirley. Brilliant and popular flowering annuals.

Beautiful Mixed. Pkt. 5c., oz. 50c.
PINKS. Annuals. Flowers of most brilliant colors, produce treely all Summer.

Splendid Double Mixed. Pkt. 5c., oz. $75 \mathrm{c}$.

PORTULACA. Annual. Adapted for dry, hot situations, producing brilliant flowers all Summer.

Choice Single Mixed. Pkt. 5c., oz. 75c.

RICINUS, or CASTOR OIL BEAN. Annuals of luxuriant growth with large, Palm-like leaves. Pkt. IOc., Oz. 30c., 1/4 lb. 75 c.

SALVIA Splendens, or Flowering Sage. Annual. Bushy plants about 3 feet high, producing dazzling scarlet flowers.

Very Choice. Pkt. Ioc., oz. \$1.50.

SALPIGLOSSIS. Beautiful garden annuals, about i 8 inches high, bearing gorgeous Petunia-like flowers.

Large flowering Mixed. Pkt. Ioc., oz. $75 \mathrm{c}$.

SCABIOSA, or MOURNING BRIDE. Also called Old Maid's Pincushion. Annual. Beautiful, large, double flowers on long stems; fine for cutting. Pkt. 5c., oz. $75 \mathrm{c}$.

STOCK. Very fragrant annual. Flowers double, and of various colors.

Large Flowering. Mixed. Extra fine. Pkt. Ioc., OZ. $75 \mathrm{C}$.

SUNFLOWER.

Mammoth Russian. Pkt. 5c., Oz. IOc., 1/4 lb. $20 \mathrm{c}$. 1b. $25 \mathrm{c}$.

SWEET WILLIAM. A favorite garden perennial, bearing heads of fragrant, richly colored flowers.

Choice Single Mixed. Pkt. 5c., oz. 50c.

Choice Double Mixed. Pkt. 5c.

VERBENA. For beds and massing the Verbena is not equaled by any other plant for profusion of bloom. brilliancy and variety of colors. They flower tle first season.

Choice Mixed. Pkt. 5c., OZ. \$I.00.

WALLFLOWER. This is a favorite European garden flower, bears long spikes or heads of ex quisitely fragrant flowers. It is very ornamental in the border, or in forming groups. Sow thinly in shallow drills in early Spring. Pkt. $5 \mathrm{c}$.

ZINNIA. A well-known annual, bearing showy flowers during Summer and Fall.

Double Mixed. Pkt. $5 \mathrm{c} ., \mathrm{Oz} .75 \mathrm{c}$.

Extra Choice Double Mixed. Pkt. 5c., 0z. \$I.00.

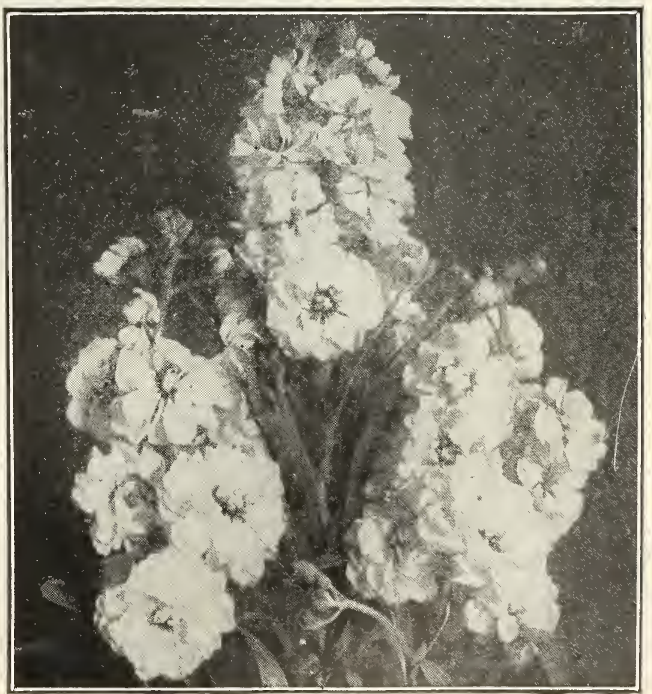

Stock 


\section{SWEET PEAS}

Culture.-Sweet Peas are, without doubt, the most beautiful and fragrant, and more generally grown than any other flower. They are of easy culture. The best way is to make a drill about 5 inches deep, dropping 4 or 5 seeds every 4 inches and covering about 2 inches, working the soil around the plant as it comes up, until it is on a level with the surface; this leaves the roots deep enough not to be affected by dry weather. They require an abundance of water. If water is applied, it should be at the roots, and not sprinkled on the vines. A trellis of brush, strings, or chicken wire is necessary. They bloom better if picked every day. Sweet Peas have been improved and developed to such an extent that there is a long list of names, many being so similar that it is hard to see any difference, except slight shades and markings of colors, and forms of hoods, or length of stems. For this reason we have discarded from our list all duplicates, and offer only the best and distinct varieties of each of the separate colors.

\section{Large-Flowering Eckford and Grandiflora Types}

Pkt. oz. 15c., lb. $1 / 4$ lb. 40 c. lb. $\$ 1.50$

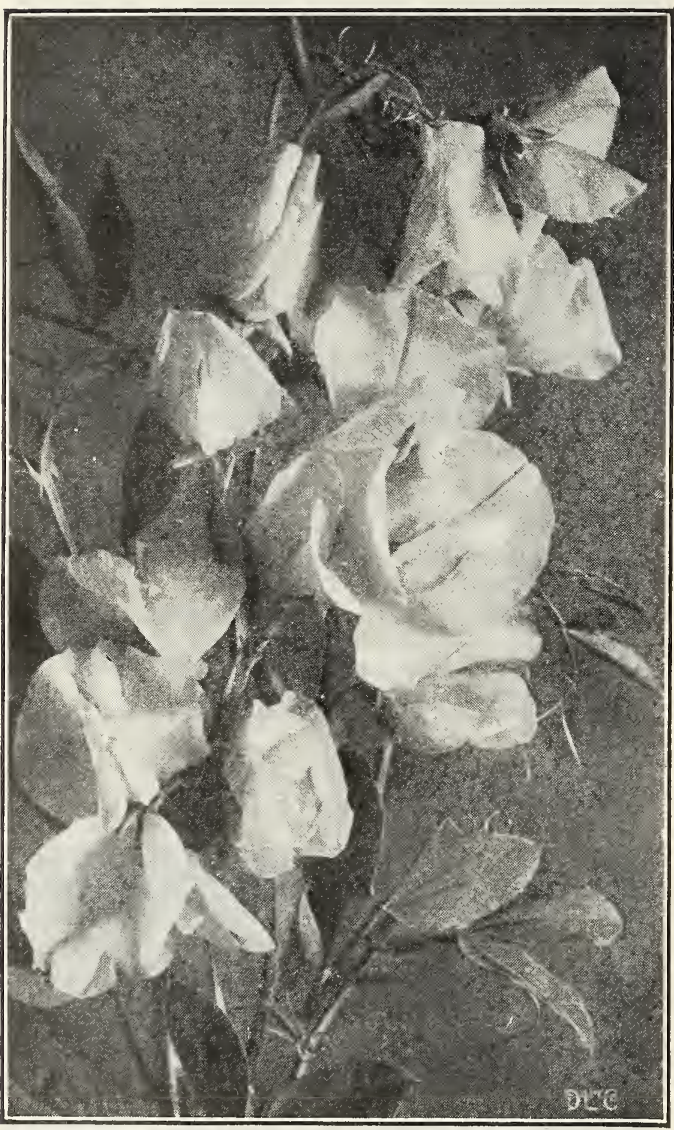

Dorothy Eckford

\section{Spencer Types}

Pkt. 10c., oz. 25c., $1 / 4$ lb. 75c., lb. $\$ 2.50$.

Asta Ohn Spencer. Pinkish lavender.

Countess Spencer. Beautiful, clear pink.

King Edward Spencer. Deep red.

Othello Spencer. Rich maroon.

White Spencer. White.

Spencer Mixed. Pkt. Ioc., oz. 20c., 1/4 lb. 60c., lb. $\$ 2.00$.
Blanche Ferry Extra Early. Pink and white.

Black Knight. Deep maroon.

Countess of Radnor. Lavender.

Dorothy Eckford. Finest pure white.

Duke of Westminster. Purple.

Janet Scott. Pure pink.

King Edward VII. Deep red.

Lord Nelson. Blue.

Lottie Eckford. Lilac, changing to blue.

Mrs. Kenyon. Yellow.

Prince of Wales. Crimson.

Choice Mixed Colors. Our mixture of colors contains ail the new and best sorts, as well as every known color and shade, and is the most beautiful blend of colorings to be found in any mixture. Pkt. 5c., oz. IOc., $1 / 4$ lb. 30c., 1b. $\$$ I.00.

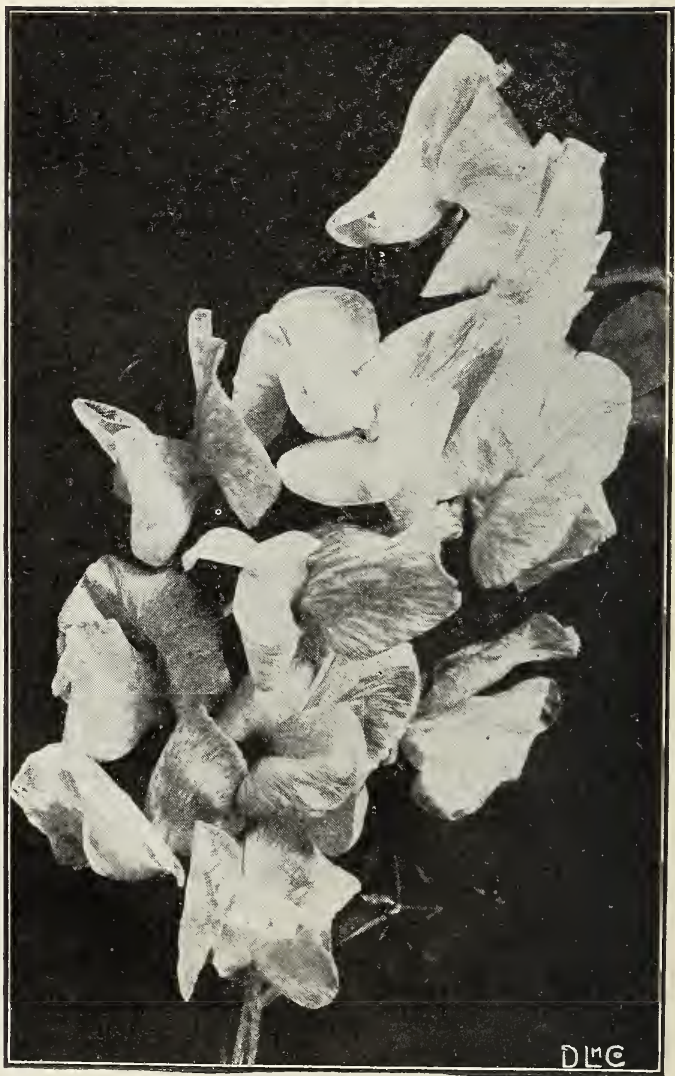

Spencer Types 


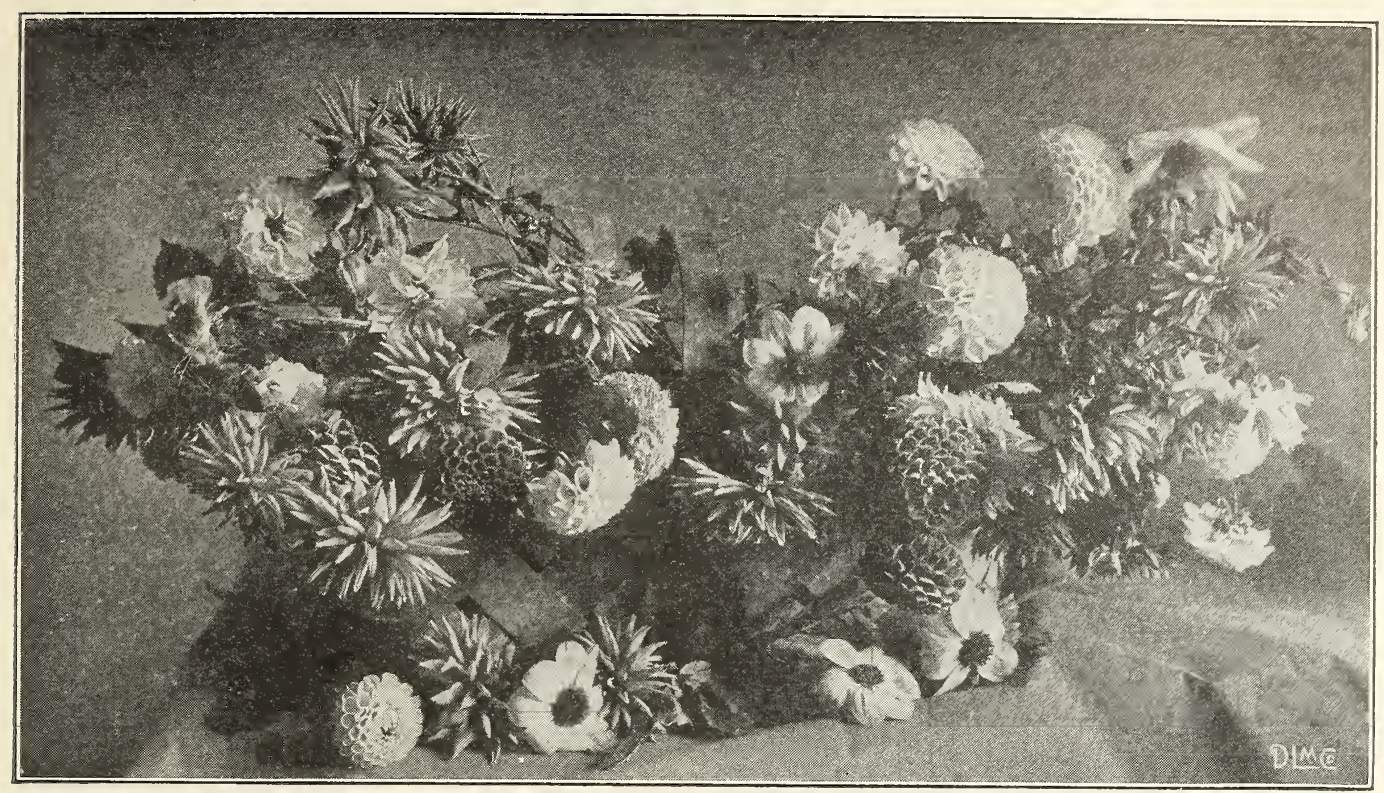

\section{SPRING BULBS FOR SUMMER FLOWERING}

Almost every garden owner appreciates the value of the Summer flowering bulbs, for among them are to be found some of our most beautiful flowers. The select list which we offer, is composed of the very choicest varieties and types of Dahlias and Gladiolus. They are strong, live bulbs, and are far superior to imported bulbs, and we believe every lover of flowers will be pleased with them.

(Order with your seeds. We will send them early in the Spring.)

\section{DAHLIA}

Culture.-There are very few flowers that compare with the Dahlia in charming diversity of form and wide range of brilliant colors, and no other surpasses it for Autumn display. The roots are tender and easily injured by frost. They should be set out 3 feet apart after all danger of frost is over. The soil should be deeply dug, and well drained. A stiff clay should be avoided. A sunny situation is desirable. Place the roots horizon'tally, covering 2 to 3 inches deep, water well during dry weather. The roots should be supported by tying to stakes. The roots should be placed during Winter in a cool cellar, but not allowed to freeze.

\section{SHOW DAHLIAS}

These are large, spherical, regular, compact and full to the center. The flowers are either solid, edged, tipped, or shaded darker.

Up to 2 doz. mailed free to any address. Golden Age. Sulphur yellow. Free flowering. Each 20c., per doz. \$2.00.

Robert Broomfield. Pure white. Tall grower. Each 20c., per doz. \$2.00.

Stradella. Beautiful deep purple-crimson. Free flowering. Stems long and wiry. Each 20c.; per doz. $\$ 2.00$.

\section{COLLARETTE DAHLIAS}

Very beautiful single flowers, with an additional row of short petals around the disc, which forms a frill or collar, usually of a different color from the rest of the flower.

Up to 2 doz. mailed free to any address.

Achievement. One of the latest novelties in Dahlias, clear, rich velvety maroon, with a frill or collar of white arranged around the golden yellow center. Each 30c., per doz. \$3.00.

Rose Pink Century. A rose pink shade. Each 20c., per doz. $\$ 2.00$.

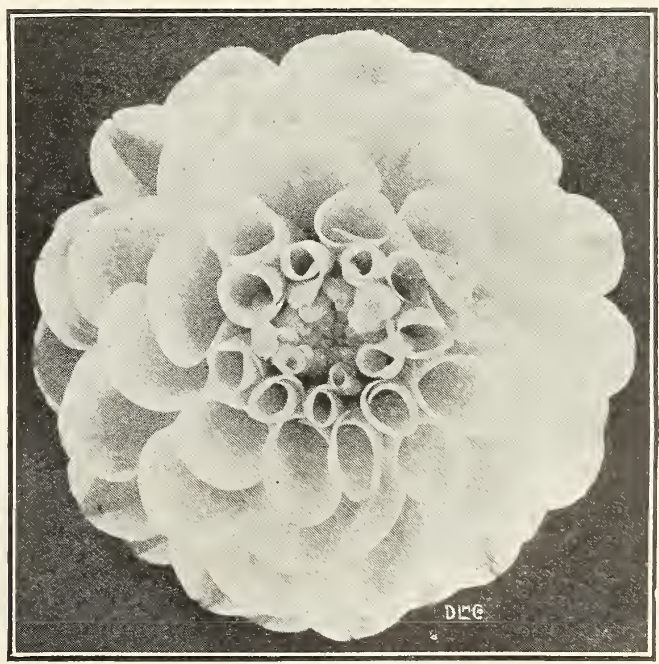

Show Dahlia 


\section{POMPON DAHLIAS}

These flowers are small, compact, and full to the center, and are produced upon long wiry stems. They bloom more freely than any of the other classes, and are the finest for cut flowers, and bouquets.

Up to 2 doz. mailed free to any address.

Amber Queen. Rich clear amber, shaded apricot, extra free flowering. Each 20 ., per doz. \$2.00.

Baron G. De Grancy. Fragrant Peony-flowered Dahlia. Flowers large white with pinkish shadings; stems long. Petals gracefully curved. A beauty in every sense of the word. Each $25 \mathrm{c}$., per doz. \$2.60.

Countess of Lonsdale. Chrysanthemum-like flowers of deep salmon-red, in great abundance. Should be in every garden. Each $30 c$., per doz. \$3.00.

Jeanne Charmet. These flowers are a most exquisite shade of lilac-pink, daintily shading to pure white toward the center, with a tinge of yellow at the margin, and measure 7 to ro inches in diameter. Each $20 c$., per doz. $\$ 2.00$.

J. H. Jackson. The finest black Cactus Dahlia in existence; superb as an exhibition flower. Color a perfectly gorgeous, deep velvety, blackish maroon. Gigantic is size. Every Dahlia lover should grow this variety. Each $25 \mathrm{c}$., per doz. \$2.60.

Le Grande Manitou. The color of this superb large flower is pure white, artistically striped, splashed and blotched deep violet purple. Each 25c., per doz . $\$ 2.60$.

Libelle. Clear deep rose purple; splendid Chrysanthemum-like flowers. Each 20c., per doz. \$2.00.

Lucy Faucett. One of the best of the fancy Dahlias, very large and free-flowering, color pale yellow, striped and splashed deep pink, with ball-shaped flowers on long stems. Each 20c., per doz., \$2.00.

\section{CANNAS}

Cannas grow rapidly and luxuriantly. Their splendid foliage, and beautiful flowers, give a gorgeous tropical effect from early Summer until frost. Planted in beds of any form or shape, in rows, or in the border, their rich foliage and showy blossoms will repay their care.

Meteor. A vigorous grower with healthy foliage. Each root produces five or six trusses of bloom, which continue flowering the entire Summer. Deep crimson, 5 feet high. Each 30c., doz. \$3.00.

Orange Bedder. This is a particularly useful and attractive bedding variety of a bright orange with just enough scarlet suffusion to intensify the dazzling mass of color when the wide, branching stems are covered with flowers. Height 4 feet. Each 30c., doz. \$3.00.

Express. Large, broad, scarlet-crimson flowers in immense trusses. (Green-leaved). This is the best dwarf red Canna. Each $35 \mathrm{c}$, doz. $\$ 3.50$.

Favorite. A rich deep golden yellow with slight red dots produced on tall stems, high above the foliage. Each 35c., doz. $\$ 3.50$.

Shenandoah. The foliage is a rich bronze. It bears fine large trusses of beautiful waxy rose-pink flowers. Each $35 \mathrm{c}$., doz. $\$ 3.00$.

City of Portland. One of the most beautiful of the pink Cannas, a fine bedding variety; well filled trusses of large flowers, green foliage. Height 3 feet. Each 3.5 c., doz. $\$ 3.50$.
Mina Burgle. A new introduction of the Decorative type, and one of the finest to date-a champion variety, producing flowers of gigantic size and remarkable beauty. Color a glowing and most brilliant scarlet. Each $25 \mathrm{c}$., per doz. \$2.60.

Queen Wilhelmina. One of the largest and best of the white Peony-flowered Dahlias. Flowers produced upon long graceful stems, well above the foliage; its immense fluffy pure white flower, showing itsjbeautiful golden center very prominently, lends an additional charm to this beautiful flower. Each $20 c$. per doz. $\$ 2.00$.

Rene Cayeux. Very free flowering Chrysanthemumlike flowers of good size, and are a beautiful rubycrimson, borne on long stems. Each 30c., per doz. $\$ 3.00$.

Souvenir de Doazon. The largest Dahlia in existance. The color is a pleasing shade of orangescarlet. Flowers are full to the center and often measure 9 inches and over in diameter, and can be forced to measure over I2 inches. Plant is a tall, vigorous grower. Should be in every garden. Each $20 c$., per doz. \$2.00.

Yellow Colosse. This magnificent variety is the best exhibition yellow in existence, being rich, refined and delicate. Large showy flowers of primrose-yellow, are produced very freely on long graceful stems. Its golden, cup-shaped petals, are daintily arranged, completing this beautiful perfect flower. Each 35c., per doz. $\$ 3.75$.

\section{DAHLIAS UNDER SEPARATE COLOR}

Up to 2 doz. mailed free to any address.

$\begin{array}{llll}\text { Red } & \text { Orange } & \text { Yellow } & \text { White } \\ \text { Maroon } & \text { Purple } & \text { Pink } & \text { Variegated }\end{array}$

Each 20c., per doz. $\$ 2.00$

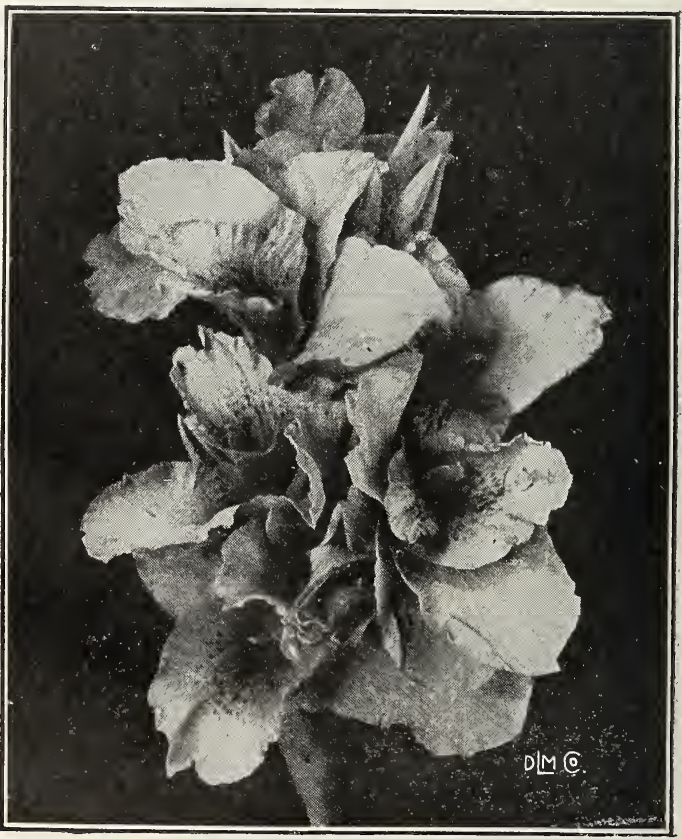

Canna King Humbert 


\section{GLADIOLUS}

The Gladioli is one of the most decorative plants in the garden, and as a cut flower lends itself readily to any arrangement. If the spikes are cui when the lowest flower is in bloom, the others will open in succession and remain fresh a week or more. No flower has gained more rapidly in public favor than the Gladiolus.

Gladioli will thrive in almost any good soil except a stiff clay. The row or bed should be 8 to io inches deep, and then spread a liberal amount of good fertilizer in the bottom of the row or bed, and rake in thoroughly before planting bulbs. Avoid rank manure. Stable dressing, and also hen dressing can be used if applied properly, but it must be put in the bottom, then cover with fully i to 2 inches of soil before the bulbs are planted. Plant the bulbs 6 to 8 inches a part, having sprout or eye facing upward, and cover about 4 inches deep. Cultivate frequently until they commence to flower.

Up to 3 doz. mailed free to any address.

America. Universally acknowledged "King of Gladiolus." Clear lavender pink. Each Ioc., per doz. $\$ 1.00$, per I00 $\$ 8.00$.

Augusta. Lovely pure white -vith blue anthers. Each roc., per doz. \$1.0o, per Ioo $\$ 8.00$.

Baron J. Hulot. The finest blue to date. A rich, deep color of indigo blue. Each Ioc., per doz. \$1.0o, per I00 $\$ 8.00$.

Brenchleyensis. Vermilion scarlet. Each Ioc., per doz. $\$$ I.0o, per roo $\$ 8.00$.

Cracker Jack. Large flowers of velvety dark red, throats spotted with yellow and dark maroon. Each IOc., per doz. \$I.0o, per I Oo \$8.00.

Halley. Very large, salmon-rose, with beautiful creamy blotch. Each IOc., per doz. \$I.00, per IOO $\$ 8.00$.

Klondyke. An early blooming plant; flowers round, well opened, of clear primrose-yellow, blotched vivid crimson in throat. Each Ioc., per doz. \$I.oo, per I00 $\$ 8.00$.

Meadowvale. One of the purest of whites, with a touch of crimson in the throat. Each IOc., per doz. $\$ 1.00$, per I00. $\$ 8.00$.

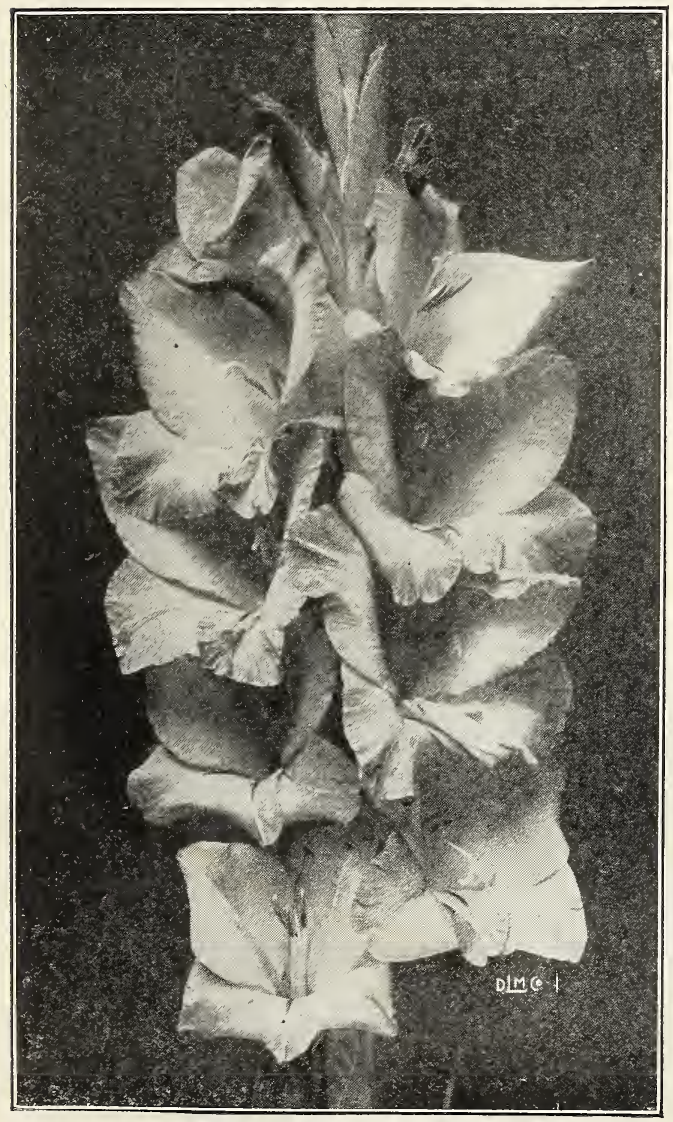

Gladiolus Metropolitan

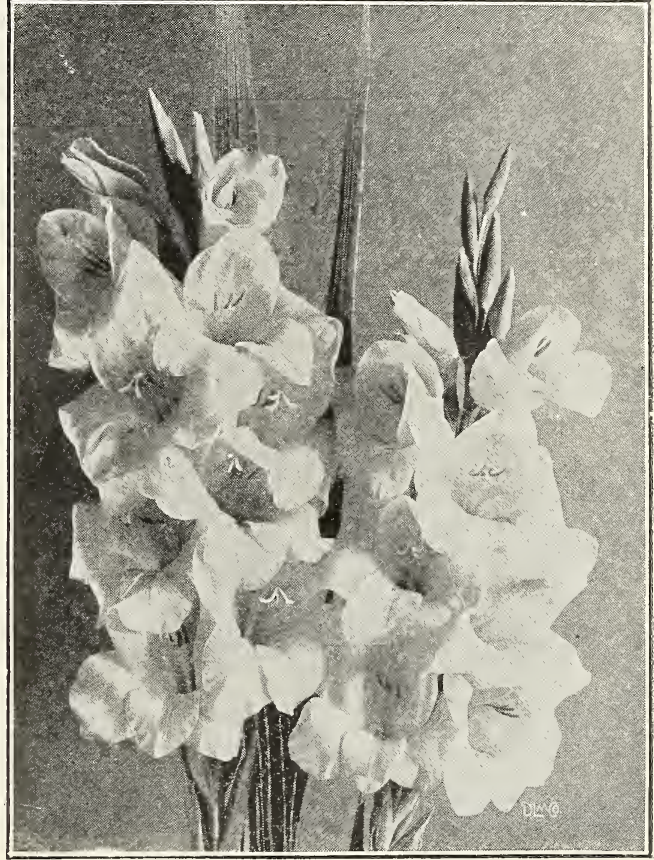

Gladiolus America

Metropolitan. Flowers of the largest size and well expanded. The color combination is most fascinating; the flowers are of light crimson scarlet with a deep cheriy throat, edged salmon-pink, the whole being beautifully striped rich crimson. Each Ioc., per doz. \$1.0o, per Ioo $\$ 8.00$.

Mrs. E. M. Smith. A new and attractive variety. Deep pink with bright cherry throat. Each Ioc., doz. $\$$ I.00, I0o $\$ 8.00$

Mrs. Francis King. A pleasing shade of light scarlet. Each Ioc., doz. \$I.00, I00 \$8.00.

Mrs. Frank Pendleton, Jr. A new variety. Color is the most exquisite salmon-pink, with a red blotch in throat. Each I5c., doz. \$1.50, I00 \$10.00.

Nazinscott. Flaming deep scarlet-red, with white mottlings in throat. Each Ioc., doz. \$1.00, I 00 \$8.00.

Niagara. A beautiful new variety, color a deep cream to primrose-yellow, throat splashed with rich carmine. Each I5c., doz. \$I.50, I00 \$10.00.

Peace. Large flowering white, with prominent purple blotch. Each I5c., doz. \$1.50, IOo \$10.00.

Panama. Color deep pink; flowers large, and spikes long. Each IOc., doz. \$1.00, I00 \$8.00.

Princeps. Rich crimson with white throat. Each IOc., doz. \$I.00, IOO \$8.00.

Sulphur Queen. A remarkable pure sulphur vellow. Each I 5 c., doz. \$1.50, I00 \$10.00.

25 at 100 rates. 


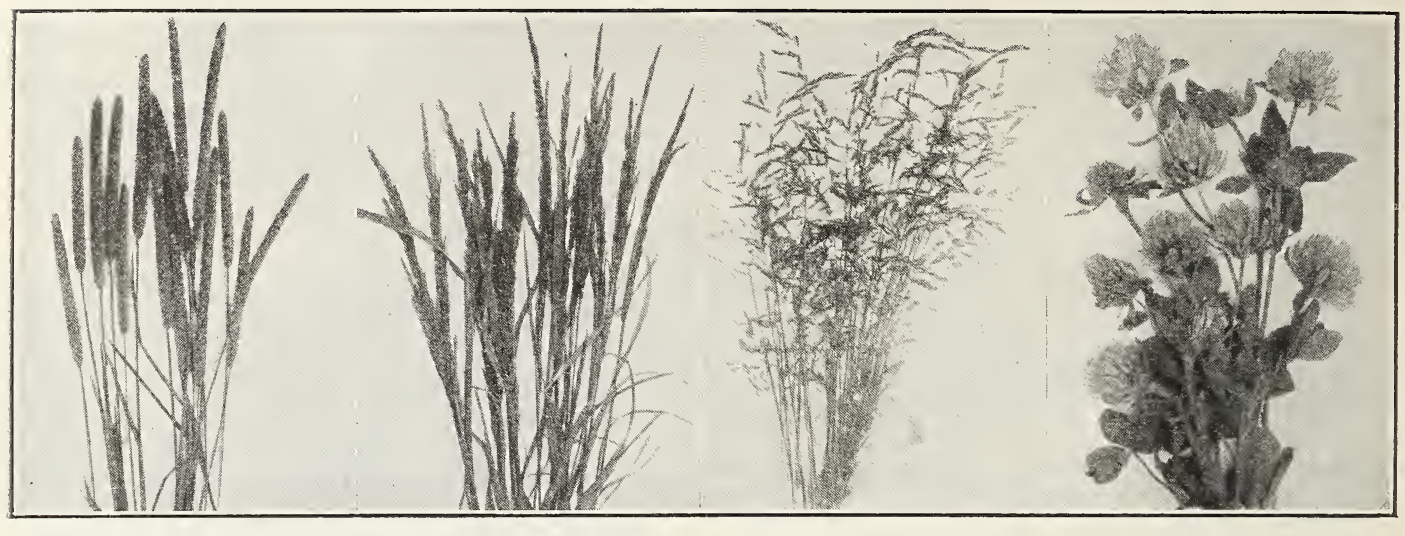

Timothy

Red Top

Kentucky Blue Grass

Red Clover

\section{GRASS SEEDS}

\section{Prices on Grass Seeds Subject to Change.}

Timothy, or Herds Grass (Choice Seed). A favorite and valuable variety, and produces large and profitable crops. Is often sown with Red Top and Clover. (Bu. 45 lbs.) Sow about 25 lbs. to the acre. Lb. I8c., Io lbs. and over I6c. per lb.

Red Top. Fancy Recleaned. Very valuable for both hay and permanent pasture. Will grow well in almost any soil moist or dry; and is a valuable addition to sow with Timothy and Clover. (Bu. 36 lbs.) Sow about $20 \mathrm{lbs}$. to the acre. Lb. $25 \mathrm{c}$., Io lbs. and over 22c. per $1 \mathrm{~b}$.

Orchard Grass. A very desirable pasture grass for stock, and will produce large crops of hay. Grows well in shady places. (Bu. I4 lbs.) Sow about 40 lbs. to the acre. Lb. 30c., Io lbs. and over $28 \mathrm{c}$. per $1 \mathrm{~b}$.

Kentucky Blue Grass. A very valuable pasture grass, and used largely in Lawn Grass Mixtures. It retains its verdure in the hottest weather. Recleaned seed $20 \mathrm{lbs}$. to the bu. For pastures sow about 40 lbs. Lb. 30c., Io lbs. and over $28 \mathrm{c}$. per $1 \mathrm{~b}$.

Mammoth Red Clover, or PeaVine. This grows much taller than Medium Red, with larger, leafier, thicker stalks, and is largely used for plowing under. (Bu. 60 lbs.). Sow about I5 lbs. to the acre. Lb. 55c., Io lbs. and over $53 \mathrm{c}$. per lb.

Medium Red Clover. This is the variety most largely sown in all sections and is the most valuable of all the varieties. (Bu. 60 lbs.) Sow about $20 \mathrm{lbs}$. to the acre. Lb. $55 \mathrm{c}$., Io lbs. and over $53 \mathrm{c}$. per $\mathrm{lb}$.

Alsike Clover. This is perennial and very hardy and thrives well on wet or dry soils. Makes excellent forage for cattle and produces large crops of sweet and fragrant hay. (Bu. 60 lbs.) Sow about 20 lbs. to the acre. Lb. $55 \mathrm{c}$., Io lbs. and over $53 \mathrm{c}$. per $\mathrm{lb}$.

Crimson Clover. An annual variety, producing large crops of green forage, or if cut while in bloom, makes excellent hay. It is also used as a grass manure and cover crop. Seed should be sown early in August or September. (Bu. 6o lbs.) Sow about 20 lbs. to the acre. Lb. 20c., Io lbs. and over, I8c. per lb.

White Clover. Will thrive well in almost every soil and climate. Is valuable in permanent pastures and in connection with Blue Grass, affords the most nutritious food for sheep and cattle. Also makes a fine mixture for lawns. (Bu. 6o lbs.). Sow about 20 lbs. to the acre. Lb. $55 \mathrm{c}$., Io lbs. and over $53 \mathrm{c}$. per $\mathrm{lb}$.

Sweet Clover-White Blossom.'Also known as Bokhara Clover and slightly resembles Alfalfa in growth, but is taller, with stiffer stems; branches freely with small fragrant white flowers, which afford an excellent food for bees.! It is a most valuable nitrogen gatherer. If cut early, before getting too large, it makes good hay. (Bu. 6o lbs.) Sow 30 lbs. to the acre. Lb. 40c., Io lbs. and over, $38 \mathrm{c}$. per $1 \mathrm{~b}$.

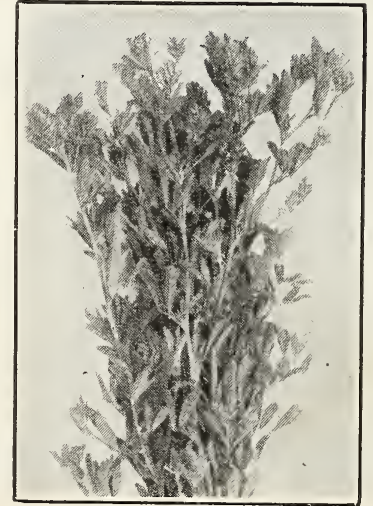

Alfalfa, or Lucerne
Alfalfa, or Lucerne. This closely resembles Clover in habits of growth and feeding value and when a stand has been secured is a most valuable crop. It is a perennial plant and will produce large crops for many years when properly cared for. If permanency is desired it must be cut every time it comes into bloom and not be allowed to run to seed. It will not succeed well on low wet soil. (Bu.6olbs.) 'Sow about 30 lbs. to the acre. Lb. $45 \mathrm{c}$., Io lbs. and over $43 \mathrm{c}$. per lb.

\section{Mixture per acre recommended for hay.}

Timothy. I5 lbs.

Red Top. 7 lbs. Clover. 5 lbs. 


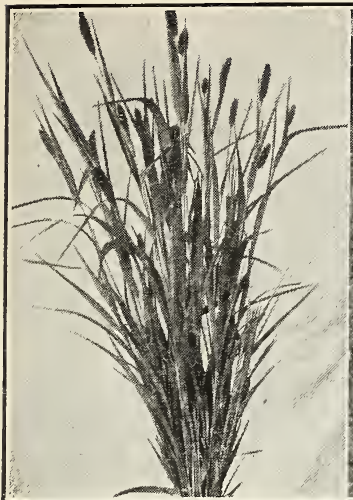

Hungarian Millet

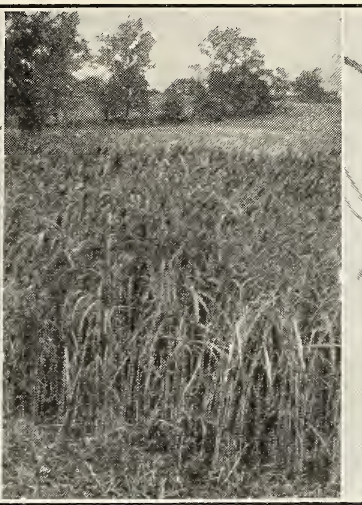

Japanese Millet

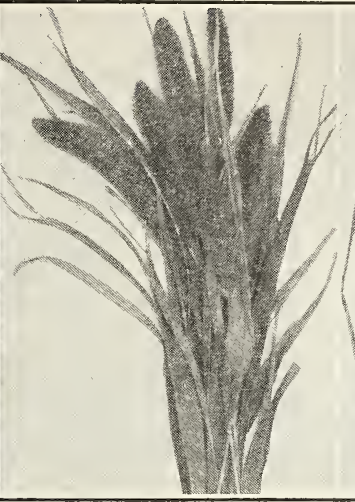

German Millet

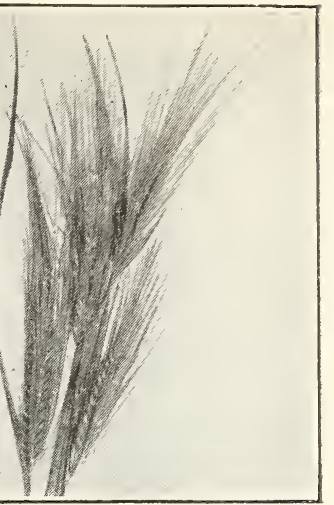

Barley

\section{MILLETS}

Hungarian Grass. This well known forage crop can be sown early in June and is ready for cutting in about 60 days. It can also be sown in July and early August, after hay crops have been harvested to help out a short crop. Resists heat and drought well. (Bu. $48 \mathrm{lbs}$ ). Sow I bu. to the acre. Lb. I5c., Io lbs. and over I $2 c$. per lb.

Japanese, or Barn Yard Millet. A forage plant of great value, growing luxuriantly on most any soil and under indifferent conditions. It will grow in seasons of extreme drought and attain a height of 6 to I2 feet. (Bu. $32 \mathrm{lbs}$.). Sow I bu. to the acre. Lb. I 5 c., Io lbs. and over, I $2 \mathrm{c}$. per lb.

Golden Millet. This is a favorite variety for planting on good land to produce a large crop of hay or forage. Matures later than Hungarian and is of stronger growth. (Bu. 5o lbs.). Sow I bu. to the acre. Lb. I5c., Io lbs. and over, I 2 c. per lb.

\section{SEED GRAINS}

Barley, Success or Beardless. This may be sown as early in the Spring as possible without danger from frost. The straw is heavy and stands up well under a heavy crop. It is also largely grown in New England as a late fodder crop. Jt withstands the most severe frost and makes the best of green feed long after other kinds are gone. (Bu. 48 lbs.). Sow about 2 bu. to the acre. Lb. I5c., I 2 lbs. and over, I2c. per lb.

Oats, Big Four. A large and heavy yielding variety. The straw stands up stiff and strong and heads well filled with white grains. Lb. $8 \mathrm{c} ., 8 \mathrm{lbs}$. and over, 5c. per lb.
Winter Rye. The time for sowing is from the middle of August to the last of September. Sow broadcast or with a drill at the rate of one and a half bushels to the acre. This has no equal as a crop to be used for late Fall or early Spring pasture and is one of the best to plow under for green manure. (Bu. 56 lbs.). Lb. 8c., Io lbs. and over, 6c. per lb.

Oats, Silver Mine. A prolific cropper and one of the most profitable varieties grown. It makes a sturdy growth of straw, which stands up well and the heads are filled with plump white grains. L'. $8 \mathrm{c} ., 8$ lbs. and over, $5 \mathrm{c}$. per $1 \mathrm{~b}$.

\section{VETCHES}

Hairy Vetches. A hardy forage plant and very productive. Its extensive root growth and nitrogengathering properties make it valuable as a soil fertilizer, also as a cover crop to prevent the land from washing during Winter storms. Seed should be sown broadcast, or drilled in, at the rate of one bushel per acre. If a half bushel of Rye is sown with the Vetch, the straw will furnish a support for the vines to run on, making them easier to mow for feed or to turn under with the plow. (Bu. $60 \mathrm{lbs}$.). Lb. 33c., Io lbs. and over 30c. per lb.

\section{SOY BEANS}

Soja, or Soy Beans. Plants grow 18 inches in height and are immensely productive. It makes a good forage crop for feeding green. The plant being a legume is valuable as a soil enricher for plowing under. Sow broadcast at the rate of one and a half bushel per acre. Lb. I2c., Io lbs. and over Ioc. per lb.

If a quantity of any of the above is wanted, write for special prices.

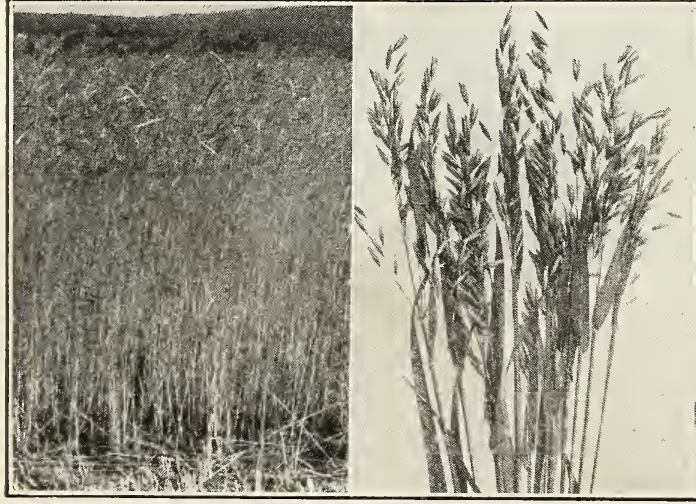

Winter Rye

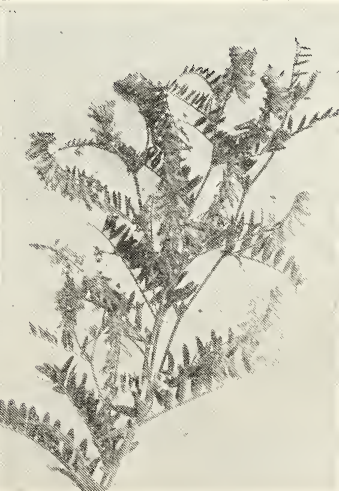

Hairy Vetch

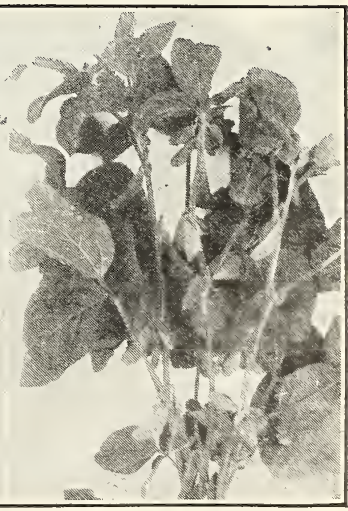

Soja Beans 


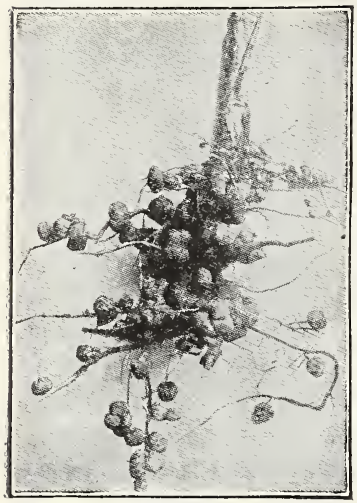

Inoculated Soy Bean Root

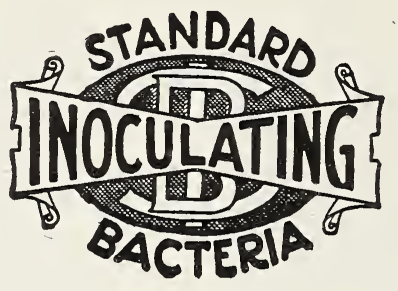

The Guaranteed Legume Inoculator

Grown Direct From Nodules, and Prepared for us by The Eggert Chemical Company
Standard Inoculating Bacteria are grown direct from the nodules. All bacteria sent out aie of the second generation from the nodules. This laboratory technic in the preparation of these culture insures the highest possible virility and therefore positive inoculation and an abundance of nodules. It is a fundamental of bacteriology that the further removed from the initial germ, the less viril. Bacteria planted and replanted to generations far remote cannot and do not insure healthy inoculation and use of such often results in failure. Standard cultures bred direct from the nodules and furnished to you only one generation removed from such to you only one generation removed from such nodule is what has placed them at the head of the
list of all legumes cultures and caused them to be the most widely used in the United States.

Standard cultures are not cheap cultures. They may be cheaper in price than some but in price only. The price is still consistent with high quality. They cannot be made better even if ten times the price were offered. Every package is fully guaranteed.

Not only in viril properties do Standard cultures excel but the character of the containers has much to do with preserving and insuring such virility right up to the time of use. They are put up in amber colored bottles (excluding the blue light ray which is deadly to many germs) with rubber corks and with glass air tubes and cotton filters. Thus prepared all foreign and destroying germs are excluded yet the nitro bacteria within the bottles are

\section{What the Experim}

Bulletin No. 53, South Carolina Experiment Station, says:

"Inoculation is not a cure all, but its proper use will send the farmer farther forward in three years than it has been possible for him to go without it in a generation.

"The peculiar values of legumes for maintaining and increasing the fertility of soils is due to certain bacteria which develop nodules upon the roots of leguminous plants and which have the unique power of rendering the free nitrogen of the atmosphere available for plant growth. Without these bacteria, legumes, like other crops, exhaust the soil of its combined nitrogen."-Ext. Farmer's Bulletin No. 315

"All legumes grown either for the purpose of enriching the soil or for the crop must, in order to be of the greatest benefit to the land and the plants, be provided with the nitrogen-fixing bacteria. It is believed that the artificial culture is the method

\section{Highest \\ Possible Virility}

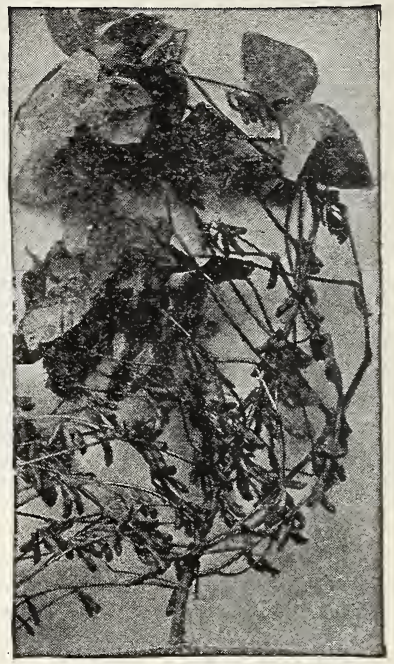

Inoculated Soy Beans

fed with sufficient nitrogen to keep them alive and viril even for years.

All legume crops should be inoculated. Few soils contain sufficient bacteria to provide self-inoculation. Artificial inoculation with pure cultures has long since been determined by the experiment stations to be the only safe and sure way. Few soils unless heavily fertilized contain enough nitrogen to carry a legume crop to maturity and a maximum yield unless the proper inoculating bacteria be present in the soil and active. Inoculated legumes take their supply of nitrogen from the air and not only feed themselves during growth but store up a surplus in the nodules formed on the roots as a supply for succeeding crops. But unless such proper bacteria are supplied or present there will be no nodules. Neither will the crop be a maximum. A good legume crop will store up in soil for use of future crops as much nitrogen as can be obtained for thirty to fifty dollars in commercial nitrogen carrying fertilizer materials. Take no chances. Inoculate all legumes with Standard cultures.

\section{ent Stations Say}

most efficient, cheapest, and freest from objectionable qualities."-Ext. Bulletin No. 71, Bureau of Plant Industry.

"It has been amply demonstrated, not only by hundreds of years of actual experience, but by numberless carefully conducted experiments in many countries and under widely varying conditions, that clover and numerous other legumes supplies with tubercle (nodule) bacteria obtain from the air through the agency of these bacteria, under favorable conditions, all the nitrogen they require, and that they leave in the soil considerable quantities for succeeding crops. In Germany the amount of nitrogen added to the soil by legumes. besides that taken off in the crop, is estimated at 200 pounds per acre. In the United States the average for sixteen States is 122 pounds equivalent to not less than 800 to 1,000 pounds of Nitrate of soda per acre."-Ext. Yearbook of Dept. of Agriculture for 1906 .

\section{Increases the Yield. Enriches the Soil. Hastens Maturity. Improves Feeding Value.
Saves Fertilizer Bills. Easy to Apply. Full Directions in Every Package.}

\section{PREPARED FOR}

$\begin{array}{lll}\text { Alfalfa } & \text { Crimson Clover } & \text { Garden Peas } \\ \text { Soy Beans } & \text { Alsike Clover } & \text { Sweet Peas } \\ \text { Cow Peas } & \text { Vetch } & \text { Field Beans } \\ \text { Sweet Clover } & \text { Field Peas } & \text { Garden Beans } \\ \text { Red Clover } & & \text { Peanuts }\end{array}$

and all other legumes

\section{PRICES}

Garden Size $\$ .50$

I Acre Size

2 Acre Size - -

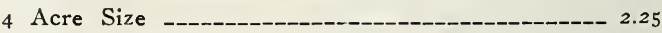

6 Acre Size -

Add five cents per package for postage. One acre size sufficient for about 20 pounds of alfalfa, clover or other small seeds, and for about 90 pounds of peas, beans or other large seeds.

When ordering, state crop to be inoculated. Standard cultures are guaranteed by us and by makers. 


\section{INSECTICIDES AND FUNGICIDES}

For Farm and Garden Use. The products listed below will help you in the control of insects, pests, blights etc., that ravage your crops. Order with your seeds. Postage or express charges to be paid by purchaser

KEY BRAND ARSENATE OF LEAD PASTE. For caterpillars and chewing insects. For spraying trees and shrubs against leaf chewing insects, fruit flies and codling moth. Contains I $5 \frac{1 / 2 \%}{2}$ Arsenic Oxide. mixes easily in water without clogging nozzle, sticks like paint, kills quick, and will not burn foliage. Dilute I lb. to 25 gallons water. I lb. $35 \mathrm{c}$., 5 lbs. $\$ \mathrm{I} .50$, Io lbs. $\$ 3.00,25 \mathrm{lbs}$. $\$ 6.25$

KEY BRAND ARSENATE OF LEAD. Fluffy (Powdered). Better than Paris green. Does not burn foliage. Has all davantages of Arsenate of Lead paste, but goes twice as far, and is easier to handle. Dilute 2 lbs. to 50 gallons water. $1 / 2 \mathrm{lb}$. $40 \mathrm{oc}$., I $\mathrm{lb}$. $60 c$., 5 lbs. $\$ 2.75$, Io lbs. $\$ 5.00,25$ lbs. $\$$ I 1.50 .

KEY BRAND BORDO LEAD (Paste). Insecticide and Fungicide. Two sprays in one. Arsenate of Lead combined with a special Bordeaux Mixture by a new process, producing in one spraying operation the killing of insects and preventing of blight, mildew, rust, etc. Splendid for potatoes and most vegetables, apples, pears and roses. Sticks like paint and remains on foliage. Best crop insurance. I lb. 40c., 5 lbs. $\$$ I. 75 , Io lbs. $\$ 3.00,25$ lbs. $\$ 6.00$.

KEY BRAND BORDEAUX MIXTURE (Liquid). For blight, mildew, rust and fungus diseases. Also prevents and cures Black Rot and Scab, and acts as a deterrent for insects on fruits and vegetables. I gallon makes 50 gallons. Qt. 50c., I gal. \$I.35, 5 gal. $\$ 6.25$.

KEY BRAND BORDEAUX MIXTURE (Powdered) Used same as Bordeaux Mixture paste or liquid. Also used for dry dusting. Dilute I lb. to 8 gallons water. $1 / 2$ lb. 25 c., I lb. 45 c., 5 lbs. $\$ 2.00$, ro lbs. $\$ 3.50,25$ lbs. $\$ 8.00$.

KEY BRAND WEED KILLER (Liquid). Destroys weeds in paths, roads and gutters. Kills roots as well as tops of all weed and grass growths. Easier and less expensive than hoeing or digging by hand. Very effective in walks or cobbled gutters, without injury to road bed. Does not discolor cement or stone. Dilutes I part Weed Killer to 40 parts water, and usually prevents growth for season. Apply with sprinkling can or cart. Qt. 6oc., I gal. $\$ 2.00,5$ gals. $\$ 9.00$.

KEY BRAND KEROSENE EMULSION. For plant lice and other soft bodied insects. Especially wool aphis, also for Rose bugs, Cabbage worms, scale and Melon louse. Conatins $55 \%$ Kerosene. Dilute I part Emulsion to ro parts water. Tender plants, I part to 25 to 50 parts water. Qt. 4 Oc., I gal. \$I.4O, 5 gal. $\$ 6.00$.

KEY BRAND KEROSENE MISCIBLE OIL. Better than Kerosene Emulsion, mixes easier, has greater killing power and is especially valuable against all soft bodied insects. Can be used on practically all insects for which Nicotine is employed. For wooly aphis on apple and thorn, it is much more effective than Nicotine. Contains $80 \%$ Kerosene. Dilute I part Oil to I6 parts water. Tender plants $x$ part to 36 parts water. I pt. $40 \mathrm{c}$., qt. $65 \mathrm{c}$., I gal. $\$ 2.25$, 5 gals. $\$ 8.00$.

KEY BRAND QUICK BORDEAUX MATERIAL. Makes best Bordeaux Mixture for apples, grapes and vegetables of all kinds. Is different from other prepared fungicides, due to the physical condition of the materials, which permit them going into solution quickly, at the same time, giving a perfect Bordeaux Mixture, fresh and strong. Put up in ro lb. packages, which makes 50 gallons of perfect Bordearix Mixture. $5 \mathrm{lb}$. packages, \$I.00, Io lb. packages, \$I.75.
KEY BRAND SCALE DESTROYER (Soluble Oil). Most effective for leaf roller. Dormant spray for San José scale. Spray for tree infesting scale and other soft bodied sucking insects. No disagreeable odor, no clogging of nozzle, or burning of the eyes like Lime Sulphur. May be used in Spring or Fall. Mixes easily, has no sediment. Dilutes I gallon to 20 gallons water. Qt. 6oc., I gal. $\$ 2.00,5$ gals. $\$ 8.00$ Io gals. \$I 4.00.

KEY-RITE DISINFECTANT. General disinfectant. Fills a long felt want. Two to three times the strength of carbolic acid. Effective for veterinary use, for household and for cleaning places occupied by cattle, horses, dogs, hogs and poultry. Qt. 40c., I gal. $\$$ I. 25,5 gals. $\$ 5.50$.

KEY BRAND TREE WOUND PAINT. Prevents decay. A residuum, penetrating, antiseptic paint that is not affected by heat, cold or moisture. Does not peel, crack or get brittle. Stops tree bleeding. Qt. 70c., I gal. \$2.00, 5 gals. \$8.0o.

KEY BRAND FLY SPRAY (Liquid). For protection of horses, cattle, dogs and hogs from flies, mosquitoes, fleas and lice. A remarkable, clean liquid spray which prevents and destroys lice and ticks on cattle and vermin on hogs and in the hen coop. Especially useful for dairymen, in preventing fretting of animals, and increases amount of milk. Harmless to use and non-penetrating. Easily applied with hand sprayer. Ot. 50c., I gal. \$I.5O, 5 gc.ls. \$6.00.

KEY BRAND BORDEAUX MIXTURE (Paste). For blight, mildew, rust and fungus diseases. Also prevents and cures Black Rot and Scab, and acts as a deterrent for insects on fruits and vegetables. Dilutes I lb. to 30 gallons water. I lb. $30 \mathrm{c}$., 5 lbs. $\$$ I.25. Io lbs. $\$ 2.25,25$ lbs. $\$ 5.00$.

\section{STANDARD FLOWER AND GARDEN FERTILIZER}

A powerful, highly concentrated and soluable plant food for

\section{Flowers, House Plants, Lawns, Shrubbery and Gardens}

The most highly concentrated and properly balanced fertilizer ever compounded.

Many times the strength of ordinary fertilizers. Never before has such a high analysis been attained.

So strong that a pinch will intensely fertilize a house plant, a small package 200 square feet.

Promotes quick and luxurious growth and deep green color to foliage and gives rich brilliant color to flowers.

Standard Flower and Garden Fertilizer will revive those puny, pale, sickly plants, flowers, shrubs, etc. A trial will convince.

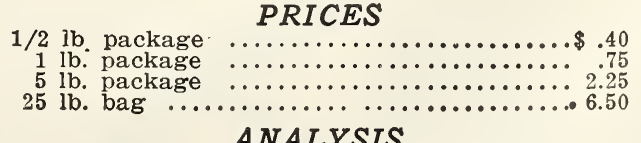

ANALYSIS

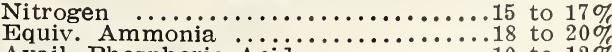

Avail. Phosphoric Acid .......................... to $12 \%$

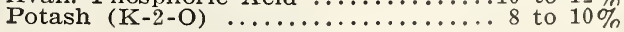

Can be used dry or dissolved in water. Full directions on every package. It is odorless. 


\section{THE MYERS' FAULT. LESS SPRAYER}

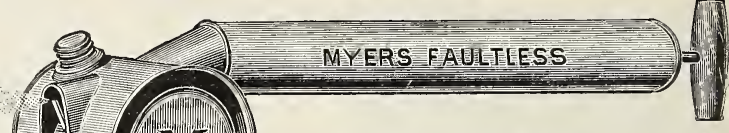

Will Spray Dry Powder

Throws a spray as fine as mist; kills, drives away and exterminates every living thing obnoxious to yourself, your animals or your crops.

Is adapted for the destroying of insects, applying disinfectants to buildings, bushes, etc.; also for applying fly chasers to animals and applying light floor oil.

The Improved Faultless Sprayer is the best constructed sprayer of its class on the market. For strength and durability, it has no equal. The tapering point to the air chamber gives great force to the spray, carrying it to the greatest possible distance. The tapering tube of air chamber is passed through the reservoir and thoroughly soldered to it. The point of the air chamber and small tube through which the liquid passes are thoroughly protected from damage while in use. The piston rod is a heavy steel spring wire with cup leather plunger.

Keep leather plunger well oiled. Always clean reservoir with clean water before putting away.

Price 75c.; expressed at purchaser's expense.

\section{GILSON GARDEN TOOLS}

\section{All tools by express at purchaser's expense.}

\section{THE LIBERTY ADJUSTABLE CULTIVATOR-WEEDER}

is the ideal tool for all-around garden cultivation, in the city garden or on the truck farm. It pulverizes the top soil into a perfect mulch which absorbs and retains moisture, permits expansion and growth of plant roots, and allows the sunlight and air to penetrate. The special design of the cutting teeth makes quick and thorough work of destroying weeds. The teeth are of unbreakable malleable iron, with sharpened cutting edges.

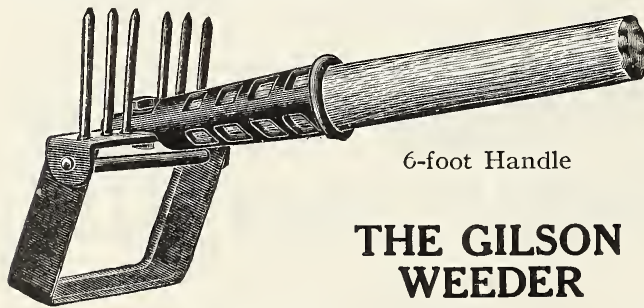

is for close work around bushy plants, as well as general gardening. The double edged rocker blade cuts both ways beneath the soil surface, destroying weeds and loosening the earth. It lightens and levels the soil and forms a perfect mulch. Every stroke counts, backward and forward. The Gilson Weeder does four times the work of the ordinary hoe, with half the effort. The 6 -foot handle permits working in a natural upright position, saving labor and backache. The weeder can be run close to plants and shrubbery without harming them, the side arms acting as fenders for the cutting blade. Price: 5-inch, heavy soil $\$ 1.10 ; 6$-inch, lighter soil $\$ 1.15$

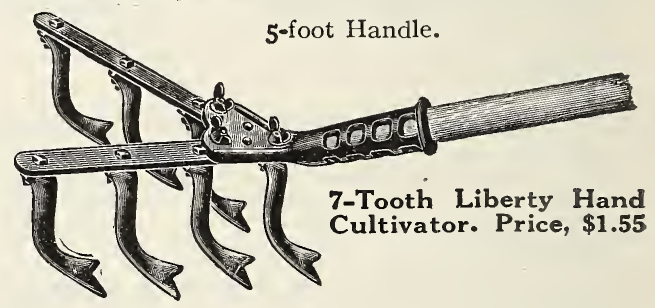

THE LIBERTY CULTIVATOR

(Hand or Wheel)

is so fashioned to do its work with the least amount of pulling force. No downward pressure is required. It adjusts to any width from 4 to Io inches between rows; middle tooth removable for straddling rows.

The Liberty Wheel Cultivator can be used with the wheel directly ahead of the cultivator, for work between rows, or the wheel may be set on the side for straddling rows.

Price............. \$3.65

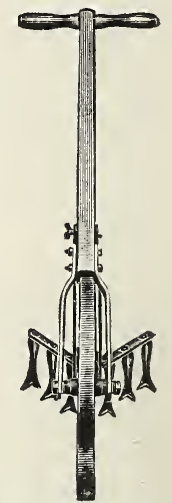

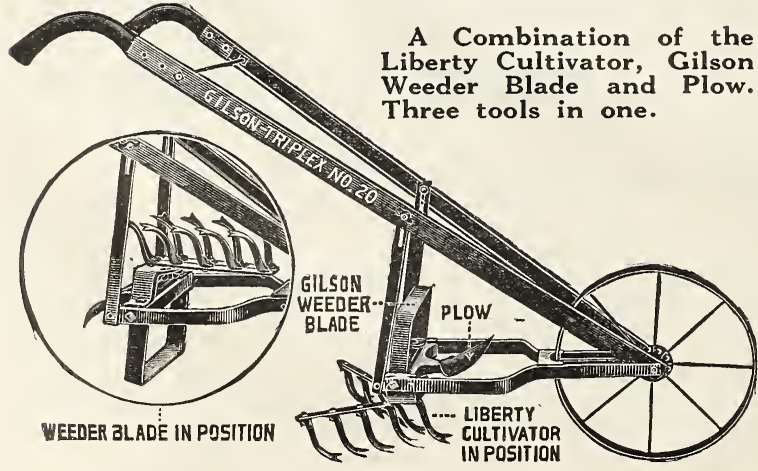

\section{THE GILSON TRIPLEX}

is a combination of the greatest garden tools on the market. It is three complete tools in one, linked together on a revolving axis, which may be firmly locked at the working position at any one of the desired tools. The adjustment from one tool to the other is simple and easy. The Gilson Weeder Blade is a weed destroyer for rough clearing, while the Liberty Cultivator is used for all-round work of preparing the seed bed, cultivating and weeding. The plow is used in seeding, cultivating narrow rows, etc. Net weight, $30 \mathrm{lbs}$. Price....................\$8.85 
Order gor 5 LDDS, etc., for

CHAS. C. HART SEED CO. Growers, Importers and Dealers

WETHERSFIELD, CONN.

Ship via

Date

Name

Town

State

Express or \{If different

Freight Office $\left\{\right.$ from $\left.P .0_{0}\right\}$

Filled by

Checked by

\section{FROM}

\section{CHAS. C. HART SEED CO.} SEEDSMEN

WETHERSFIELD, CONN.

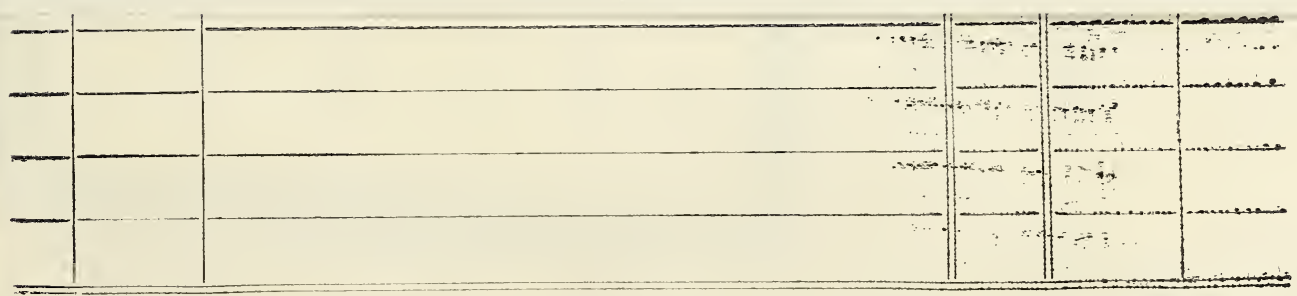

Salesman

Ordered by

Date 


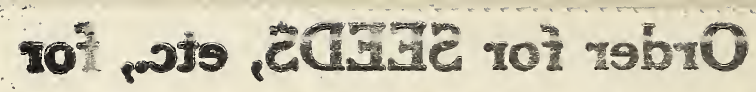

.02 ब그 ТЯAH .2 2АНว

CH

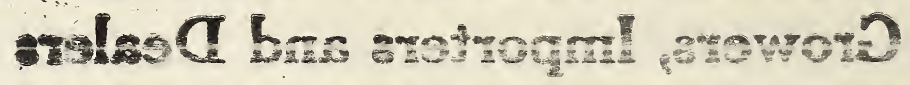

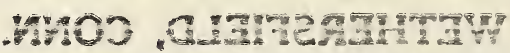

N

F

9160

siv qiild

H. $2 \cdots \cdots \cdots$

(1)

эmsh

SP

atet?

rwo T

you.

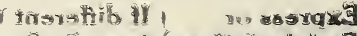

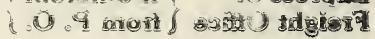

fly :

it $t i$

oug.

pro1

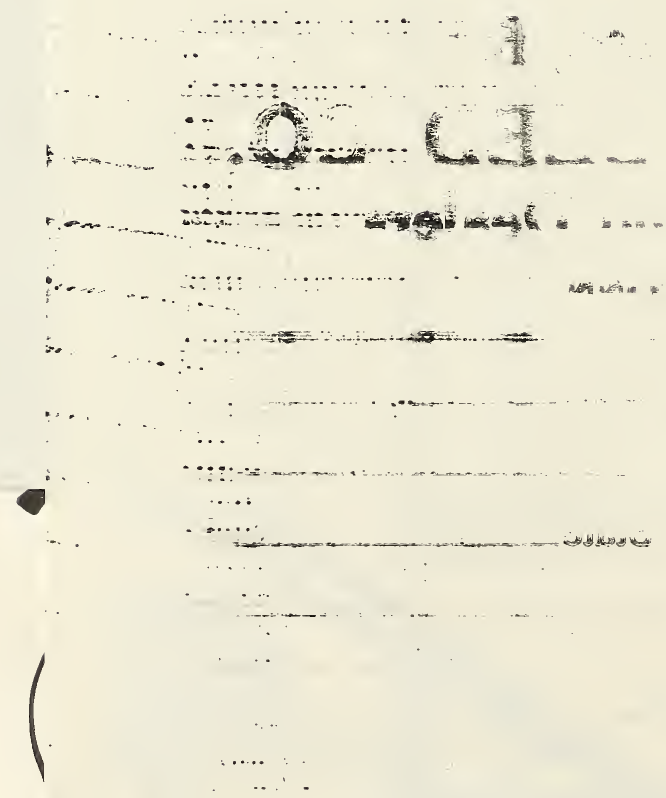




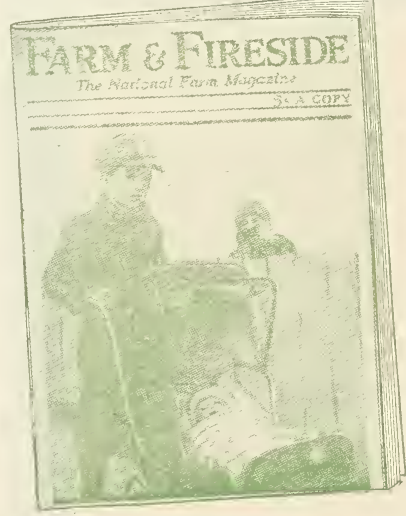

Subscription Rate One Year, 50 Cents

A R M AND

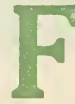

\section{The National Farm Magazine}

\section{Why Every Farmer Should Read It}

Because Farm and Fireside's real editors are practical farming men and women scattered all over the country.

Because - These editors tell you in their own words, so it will be useful to you personally, how they have worked out their own farming problems.

Because Farm and Fireside realizes that your problems of getting more money, better clothes, easier work, contented children, comfortable homes, and good educations, stand on the same plane as the problems of folks in other lines of business, and is edited accordingly.

Because Farm and Fireside aims to have every reader get from each issue at least one idea he can personally translate into a bettered farm, a happier life, and a fatter pocketbook.

Because - More than 700,000 other farm people read it, and get good from it.

\section{USE OTHER SIDE TO ORDER THIS HELPFUL FARM MAGAZINE.}






